
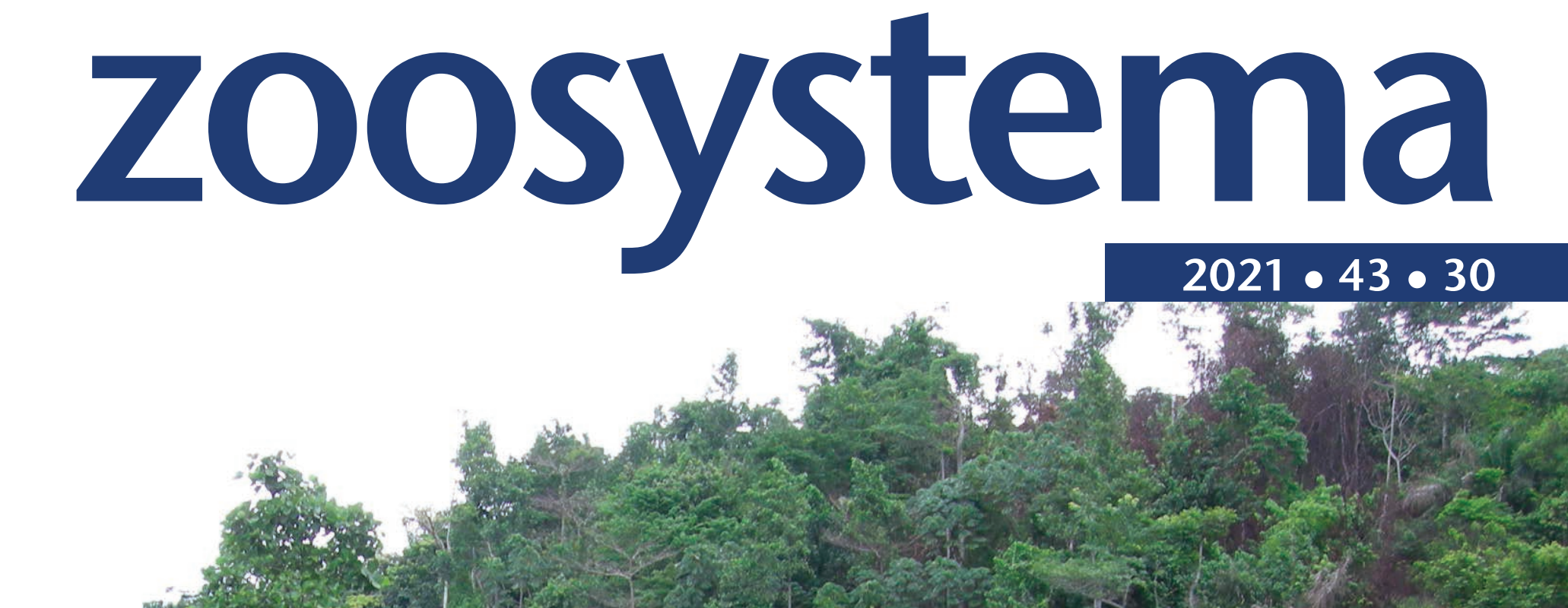

4 4. 4.5 Shrews (Mammalia, Eulipotyphla) from a biodiversity hotspot, Mount Nimba (West Africa), with a field identification key to species

Christiane DENYS, François JACQUET,Blaise KADJO, Alain Didier MISSOUP, Vladimir ANISKINE, Joelle GOÜY DE BELLOCQ, Barré SOROPOGU, Mory DOUNO, Morlaye SYLLA, Violaine NICOLAS, Aude LALIS \& Ara MONADJEM

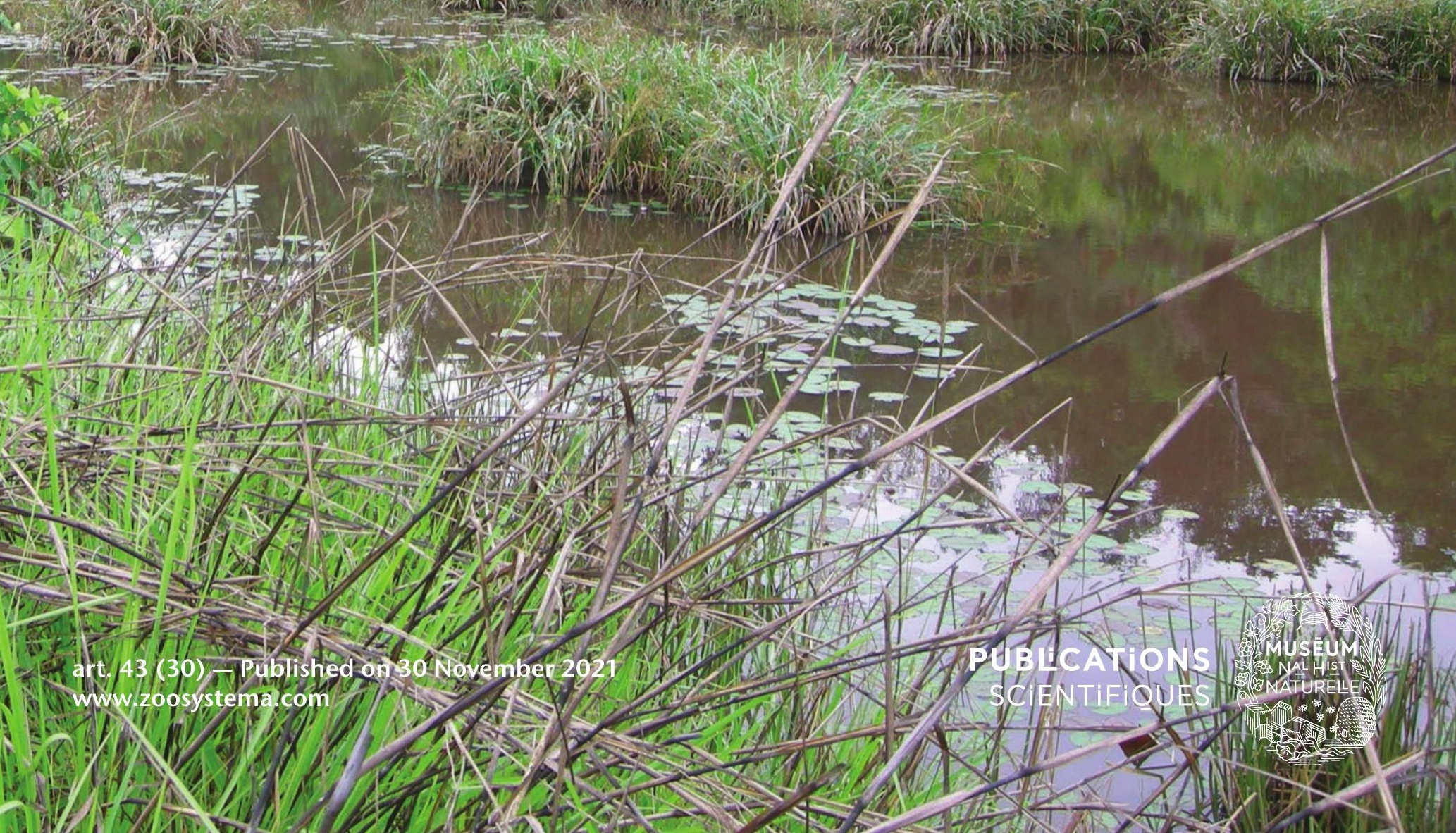


Directeur de LA publication / Publication diRECTOR: Bruno David

Président du Muséum national d'Histoire naturelle

RÉDACTRICE EN CHEF / EDITOR-IN-CHIEF: Laure Desutter-Grandcolas

AsSISTANTE DE RÉDACTION / AsSISTANT EDITOR: Anne Mabille (zoosyst@mnhn.fr)

Mise en PAge / Page Layout: Anne Mabille

COMITÉ SCIENTIFIQUE / SCIENTIFIC BOARD:

Nesrine Akkari (Naturhistorisches Museum, Vienne, Autriche)

Maria Marta Cigliano (Museo de La Plata, La Plata, Argentine)

Serge Gofas (Universidad de Málaga, Málaga, Espagne)

Sylvain Hugel (CNRS, Université de Strasbourg, France)

Marco Isaia (Università degli Studi di Torino, Turin, Italie)

Rafael Marquez (CSIC, Madrid, Espagne)

Jose Christopher E. Mendoza (Lee Kong Chian Natural History Museum, Singapour)

Annemarie Ohler (MNHN, Paris, France)

Jean-Yves Rasplus (INRA, Montferrier-sur-Lez, France)

Wanda M. Weiner (Polish Academy of Sciences, Cracovie, Pologne)

COUVERTURE / COVER:

Examples of habitats where pitfall traps were placed on the Guinean and Liberian Nimba: gallery forest and swamp, camp 4 (Liberia).

Zoosystema est indexé dans / Zoosystema is indexed in:

- Science Citation Index Expanded (SciSearch ${ }^{\circledR}$ )

- ISI Alerting Services ${ }^{\circledR}$

- Current Contents ${ }^{\circledR} /$ Agriculture, Biology, and Environmental Sciences ${ }^{\circledR}$

- Scopus ${ }^{\circledR}$

Zoosystema est distribué en version électronique par / Zoosystema is distributed electronically by:

- BioOne ${ }^{\circledR}$ (http://www.bioone.org)

Les articles ainsi que les nouveautés nomenclaturales publiés dans Zoosystema sont référencés par /

Articles and nomenclatural novelties published in Zoosystema are referenced by:

- ZooBank ${ }^{\circledR}$ (http://zoobank.org)

Zoosystema est une revue en flux continu publiée par les Publications scientifiques du Muséum, Paris / Zoosystema is a fast track journal published by the Museum Science Press, Paris

Les Publications scientifiques du Muséum publient aussi / The Museum Science Press also publish:

Adansonia, Geodiversitas, Anthropozoologica, European Journal of Taxonomy, Naturae, Cryptogamie sous-sections Algologie, Bryologie, Mycologie.

Diffusion - Publications scientifiques Muséum national d'Histoire naturelle

CP $41-57$ rue Cuvier F-75231 Paris cedex 05 (France)

Tél.: 33 (0)1 40794805 / Fax: 33 (0)1 40793840

diff.pub@mnhn.fr / https://sciencepress.mnhn.fr

(C) Publications scientifiques du Muséum national d'Histoire naturelle, Paris, 2021

ISSN (imprimé / print): 1280-9551/ ISSN (électronique / electronic): 1638-9387 


\title{
Shrews (Mammalia, Eulipotyphla) from a biodiversity hotspot, Mount Nimba (West Africa), with a field identification key to species
}

\author{
Christiane DENYS \\ François JACQUET \\ Institut de Systématique, Évolution, Biodiversité (ISYEB), \\ Muséum national d'Histoire naturelle, CNRS, Sorbonne Université, EPHE, Université des Antilles \\ UMR 7205, case postale 51, 57 rue Cuvier, F-75231 Paris cedex 05 (France) \\ christiane.denys@mnhn.fr (corresponding author) \\ Blaise KADJO \\ Laboratoire de Zoologie et Biologie - UFR Biosciences- \\ Université Félix Houphouët-Boigny (Côte d'Ivoire) blaisekadjo1@hotmail.com
}

Alain Didier MISSOUP

Zoology Unit, Laboratory of Biology and Physiology of Animal Organisms, Faculty of Science, University of Douala, POBox 24157 Douala (Cameroon) admissoup@ymail.com

Vladimir ANISKINE Severtsov Institute of Ecology and Evolution, Russian Academy of Sciences, Leninskii pr 33, 117071 Moscow (Russia) anivlad@gmail.com

Joelle GOÜY DE BELLOCQ Institute of Vertebrate Biology, Research Facility Studenec, Czech Academy of Sciences, Květná 8, 60365 Brno (Czech Republic) joellegouy@gmail.com

Barré SOROPOGUI Projet de Recherche sur les Fièvres Hemorragiques en Guinée, C.H.U. Donka, 5680 Conakry (Guinea) barresoropogui@gmail.com

Mory DOUNO Centre de Gestion de l'Environnement des monts Nimba et Simandou (CEGENS), ministère de l'Environnement des Eaux et Forêts (Guinea) morydouno2001@gmail.com

Morlaye SYLLA Centre d'Études et de Recherches sur les Petits Animaux, Université Gamal Abdel Nasser, 2580 Conakry (Guinea) morlaye2011@yahoo.fr

Violaine NICOLAS

Aude LALIS

Institut de Systématique, Évolution, Biodiversité (ISYEB), Muséum national d'Histoire naturelle, CNRS, Sorbonne Université, EPHE, Université des Antilles, UMR 7205, case postale 51, 57 rue Cuvier, F-75231 Paris cedex 05 (France) vnicolas@mnhn.fr; aude.lalis@mnhn.fr

Ara MONADJEM

Department of Biological Sciences, University of Eswatini, Private Bag 4, Kwaluseni, Eswatini \& Mammal Research Institute, Department of Zoology \& Entomology, University of Pretoria, Private Bag 20, Hatfield 0028, Pretoria (South Africa) aramonadjem@gmail.com 
Denys C., Jacquet F., Kadjo B., Missoup A. D., Aniskine V., Goüy de Bellocq J., Soropogui B., Douno M., Sylla M., Nicolas V., Lalis A. \& Monadjem A. 2021. - Shrews (Mammalia, Eulipotyphla) from a biodiversity hotspot, Mount Nimba (West Africa), with a field identification key to species. Zoosystema 43 (30): 729-757. https://doi.org/10.5252/ zoosystema2021v43a30. http://zoosystema.com/43/30/

\section{ABSTRACT}

In this study, we collected 226 shrew specimens originating from 16 localities on the Guinean and Liberian sides of Mount Nimba. We surveyed all major vegetation zones from 400 to $1600 \mathrm{~m}$ above sea level (asl), including forest and savannah habitats. We recorded 11 species, whose identifications were confirmed by genetic analyses and classical morphometrics. Furthermore, we provide cytogenetic data for five of these species. The shrew community at Mount Nimba is composed of a mix of both savannah- and forest-dependent species, which is related to the peculiar position of Mount Nimba situated at the transition between lowland rainforest to the south and Guinean woodlands to the north. We recorded 11 species of shrews in syntopy in lowland rainforest, seven in edaphic savannah and mountain forest, and five in high-altitude savannah at $1600 \mathrm{~m}$ asl. Based on morphometric analyses, we show that these syntopic species separate along a size axis, allowing species to occupy different ecological niches, which we speculate allows them to access different food resources. We also highlight that Crocidura theresae Heim de Balsac, 1968 from Mount Nimba has a different karyotype from that described in Côte d'Ivoire. Finally, we develop a novel identification key for shrews from Mount Nimba using external characters and standard body measurements, allowing it to be used in the field on live specimens. In total 12 shrew species are now known from Mount Nimba, which highlights its exceptional position as a tropical African biodiversity hotspot.

\section{RÉSUMÉ}

Musaraignes (Mammalia, Eulipotyphla) d'un point chaud de biodiversité, le mont Nimba (Afrique de l'Ouest), avec une clef d'identification des espèces.

Dans cette étude, nous avons collecté 226 spécimens de musaraignes dans 16 localités des versants guinéen et libérien du mont Nimba. Nous avons exploré les zones majeures de végétation de 400 à $1600 \mathrm{~m}$ d'altitude, incluant les habitats de forêt et de savanne. Nous dénombrons 11 espèces dont les identifications ont été confirmées par analyses génétiques et de morphométrie classique. De plus, nous présentons des données cytogénétiques pour cinq espèces. La communauté des musaraignes du mont Nimba est composée d'un mélange d'espèces savanicoles et forestières. Ceci est à mettre en relation avec la position particulière du mont Nimba qui est situé à la transition entre la forêt de plaine au sud et la savanne guinéenne au nord. Nous avons capturé 11 espèces en syntopie dans la forêt de plaine, sept dans les savannes édaphiques et la forêt de montagne et cinq dans la savanne d'altitude à $1600 \mathrm{~m}$. À partir des analyses morphométriques nous montrons que les espèces syntopiques se séparent le long d'un axe de taille, ce qui permet aux espèces d'occuper des niches écologiques variées et suggère que cela facilite l'accès à des ressources alimentaires distinctes. Nous montrons que Crocidura theresae Heim de Balsac, 1968 du mont Nimba possède un karyotype différent de ceux décrits en Côte d'Ivoire. Finalement, nous présentons une clef d'identification des musaraignes du mont Nimba utilisant les caractères externes et les mesures corporelles standard afin de permettre son utilisation sur le terrain pour des spécimens vivants. Au total, 12 espèces de musaraignes sont maintenant connues au mont Nimba, ce qui met en évidence sa situation exceptionnelle en tant que point chaud de biodiversité en Afrique tropicale.

\section{INTRODUCTION}

Eulipotyphla Waddell, Okada \& Hasegawa, 1999, which includes shrews (family Soricidae G.Fischer, 1814), hedgehogs (Erinaceidae G.Fischer, 1814), moles (Talpidae G.Fischer, 1814) and solenodons (Solenodontidae Gill, 1872), represents the third most diverse order within Mammalia after Rodentia Bowdich,1821 and Chiroptera Blumenbach,1779 (Hutterer 2005). The Soricidae comprises 25 genera and 448 species (Burgin \& He 2018). Within Africa, both shrew diversity and endemism are high in the Guineo-Congolian rainforest block (Kasangaki et al. 2003; Nicolas et al. 2005; Gambalemoke et al. 2008; Igbokwe et al. 2019). The western part of this forest block, which forms the Upper Guinea rainforest zone, has been identified as one of 25 biodiversity hotspots in the world (Myers et al. 2000). It harbours numerous endemic species and an exceptional diversity, which is far from being exhaustively known. For example, many cryptic species of small mammals have been recently recognized and described in this region (Nicolas et al. 2009; Denys \& Aniskine 2012; Jacquet et al. 2012; Monadjem et al. 2013, 2016; Decher et al. 2015; Hutterer et al. 2019; Monadjem et al. 2021). There are currently 16 species of soricid shrews described from the Upper Guinean rain forest (Burgin \& He 2018), some of which are of 
conservation concern, e.g. Crocidura nimbae Heim de Balsac, 1956, C. buettikoferi Jentink, 1888, C. grandiceps Hutterer, 1983 that are listed as globally "Near Threatened" (IUCN, 2019), or have restricted geographical ranges, e.g. C. nimbasilvanus Hutterer, 2003 (Jacquet et al. 2013). Furthermore, some species are of socioeconomic importance being hosts for hantaviruses (Klempa et al. 2007; Kang et al. 2011).

The diversity of small mammals, and especially of shrews, is promoted by factors acting as biogeographical barriers such as different vegetation zones (Jacquet et al. 2014), rivers (Stanley \& Esselstyn 2010; Jacquet et al. 2013), or mountains (Stanley \& Olson 2005; Stanley \& Esselstyn 2010). Mount Nimba, which is situated at the triple frontier point between Guinea, Liberia and Côte d'Ivoire, constitutes one of the three highest West African mountains (1752 m above sea level). Mount Nimba has been subject to several surveys aimed at understanding the structuring of its plant and animal communities (see Coe 1975 and references therein). Stratification of the vegetation is observed along the elevational gradient, with lowland forest up to $600 \mathrm{~m}$, mid-elevation forest between 600 and $1200 \mathrm{~m}$ and edaphic altitude savannah above $1200 \mathrm{~m}$. This latter habitat is known to offer isolation conditions for both plant and animal species owing to its distinct climate and vegetation characteristics (Coe 1975; Lamotte \& Roy 2003). For this reason, Mount Nimba may act as a biodiversity promoter (White 1981). Moreover, it is situated in the ecotone zone between rainforest and savannah, which is high in diversity (Fahr \& Kalko 2011), and is known to play an important role in speciation processes (Schilthuizen 2000).

Mount Nimba houses several endemic or near-endemic species including the toad Nimbaphrynoïdes occidentalis (Angel,1943), the afrosoricid Micropotamogale lamottei Heim de Balsac, 1954 the rodent Dendromus lachaisei Denys \& Aniskine, 2012, and the bats Hipposideros lamottei Brosset, 1984 and Neoromicia roseveari Monadjem, Richards, Taylor \& Stoffberg, 2013 (Denys \& Aniskine 2012; Monadjem et al. 2013, 2016, 2019). Furthermore, the two shrews Crocidura nimbae and Crocidura nimbasilvanus are near-endemics occurring on this mountain and in surrounding areas (Mamba et al. 2021).

The shrews of Mount Nimba have been the subject of several historical surveys (Heim de Balsac 1958; Coe 1975; Verschuren \& Meester 1977). Highlighting the uniqueness of this mountain, five species of the genus Crocidura Wagler, 1832 have their type locality in Mount Nimba: C. nimbae Heim de Balsac, 1956, C. jouvenetae Heim de Balsac, 1958, C. obscurior Heim de Balsac, 1958, C. theresae Heim de Balsac, 1968 and $C$. nimbasilvanus Hutterer, 2003. In total, two genera and 12 species are currently known from the massif: the five previously-mentioned species, plus C. buettikoferi Jentink, 1888, C. grandiceps Hutterer, 1983, C. douceti Heim de Balsac, 1957, C. muricauda (Miller, 1900), C. olivieri (Lesson, 1827) and Suncus megalurus (Jentink, 1888) (Heim de Balsac, 1958; Hutterer, 2005). Other species that may occur include C. crosse $i$ Thomas, 1895 and C. lamottei Heim de Balsac, 1968, both of which were previously reported from nearby regions (Decher et al. 1997; Grubb et al. 1998; Jacquet et al. 2012). On the Ivorian side of Mount Nimba, C. eburnea Heim de
Balsac, 1958 was described from Mount Tonkoui as a subspecies of $C$. obscurior before being recently elevated to full species level following detailed molecular analysis (Jacquet et al. 2014). Two other species, C. poensis (Fraser, 1843) and C. denti Dollman, 1915 are often described as being present from the vicinity of Mount Nimba (Wilson \& Mittermeier 2018) but recent molecular studies show that they probably represent misidentifications (Dambry et al. 2016; Nicolas et al. 2019). Eleven of the 12 species recorded from Mount Nimba were recently validated through an integrative taxonomic approach using morphological and molecular data (Dubey et al. 2008; Jacquet et al. 2012).

Cytogenetic analyses have also been successfully employed to assess the validity of shrew species and to explore intraand inter-specific variability (Meylan \& Vogel 1982; Schlitter et al. 1999). Several cytogenetic studies have been conducted in West Africa, especially in Côte d'Ivoire and Burkina Faso (Meylan 1967, 1971; de Hondt 1974; Meylan \& Vogel 1982; Maddalena \& Ruedi 1994; Baskevitch et al. 1995; Lavrenchenko et al. 1997; Schlitter et al. 1999), however many gaps remain in our knowledge of the intra- and inter-specific variability in the karyotypes of shrews in West Africa, and no karyotypes have been published for shrews at Mount Nimba.

Despite progress made with resolving the taxonomy and systematic relationships of West African shrews, little is known about their ecological requirements and morphological variability. Morphometric analyses are useful in describing the variability within and between species, and have been used to demonstrate that in species-rich shrew communities such as those in African rainforests, species are typically ordered along a size gradient (Hutterer et al. 1987; Brosset 1988; Churchfield et al. 1999). It has been suggested that this assists partitioning access to food resources, allowing these species to co-exist sympatrically or even syntopically (Hutterer et al. 1987).

A serious challenge to research on West African shrews is the difficulty with species identification. Indeed, tools allowing rapid and accurate identification of species in the field are totally lacking; even the most recent and comprehensive synthesis of African mammals 'Mammals of Africa' does not present characters for distinguishing different species of the super-diverse genus Crocidura (Happold \& Happold 2013). To complicate matters, the morphology of shrews may vary with environmental factors (Rácz \& Demeter 1998; Wójcik et al. $2000,2003)$. As a result, the identification of species in the field is challenging even for specialist taxonomists, especially owing to the paucity of available external characters (e.g. fur and skin colour, tail length and thickness, quantity and length of tail vibrissae) for the discrimination of species (Heim de Balsac 1956, 1958, 1968; Hutterer \& Happold 1983). An identification key was presented by Hutterer \& Happold (1983) for Nigerian shrews but is mostly inapplicable to the Upper Guinea rainforest, since species composition is different. Given the important status of Mount Nimba (Monadjem et al. 2016), the development of an identification key based on external and morphometric characters would be highly useful.

The aim of this paper is to synthesize our recent work on shrew diversity at Mount Nimba by: 1) providing a faunal 
list with information on habitat and ecological requirements; 2) describing karyotypes of Mount Nimba shrews and comparing them with those available for other West African localities in the literature; 3) exploring the morphological variability within and between species in order to understand how diverse communities are structured; and 4) providing a new identification key easily usable in the field. We have at our disposal a valuable collection of genotyped specimens that represents a unique opportunity to update our knowledge on the distribution, ecology, and morphology of shrew taxa from this biodiversity hotspot.

\section{MATERIAL AND METHODS}

\section{STUDY AREA AND BIOLOGICAL MATERIAL}

Mount Nimba is an isolated massif of about 40 kilometers length, composed of Precambrian rocks, situated at the triple frontier point between Guinea, Liberia and Côte d'Ivoire. It is sometimes considered as a range constituted of different peaks all situated on the Guinean side: Mount Richard Molard (1752 m), Mount Semperé (1682 m), Mount Leclerc $(1577 \mathrm{~m})$, Mount Pierré Richaud (1670 m), Mount Tô $(1675 \mathrm{~m})$. This range is partially protected under the name: Mount Nimba Strict nature reserve and Mount Nimba Biosphere reserve and world heritage that is found in Guinea and Côte d'Ivoire and includes only Mount Richard Molard known as Mount Nimba.

In 2003, Liberia proclaimed the East Nimba Nature Reserve (ENNR) covering most of the Liberian part of the mountain, whose management costs are currently subsidized by ArcelorMittal that views it as a possible offset site for its operations. In contrast, the entire Guinean and Ivorian parts of the mountain were protected from 1944 onwards. The Mount Nimba Strict Nature Reserve (La Réserve naturelle intégrale du Mont Nimba), was initially established by the former French colonial government in 1943 by Order no. 4190 $\mathrm{SE} / \mathrm{F}$ in Côte d'Ivoire and subsequently by decree in Guinea in 1944 (JO-RF, 1944). In 1980 the Guinean portion of the Strict Nature Reserve was proclaimed a Biosphere Reserve. The Mount Nimba Strict Nature has been recognised as a single transboundary 'Natural World Heritage Site' (NWHS) by UNESCO since 1981 (Cote d'Ivoire section) and 1982 (Guinea section) (Granier \& Martinez 2011). Nevertheless, this ecosystem is currently threatened by intensive human activities like cacao, coffee, rubber and oil palm cultures, forestry and iron ore exploitation.

During biodiversity inventories performed from 2008 to 2013, we trapped shrews at several localities on the Guinean and Liberian sides of Mount Nimba. During the dry (February-March 2008, December 2009-January 2010, December 2010-January 2011) and wet (October 2008) seasons, 153 shrew specimens were trapped using Sherman and pitfalls traps at five localities in Guinea (Table 1). In 2011 and 2013 we collected 73 additional shrews at 11 localities in Liberia, in the ArcelorMittal concession including the ENNR. We surveyed all habitats encountered on this mountain, i.e., lowland and

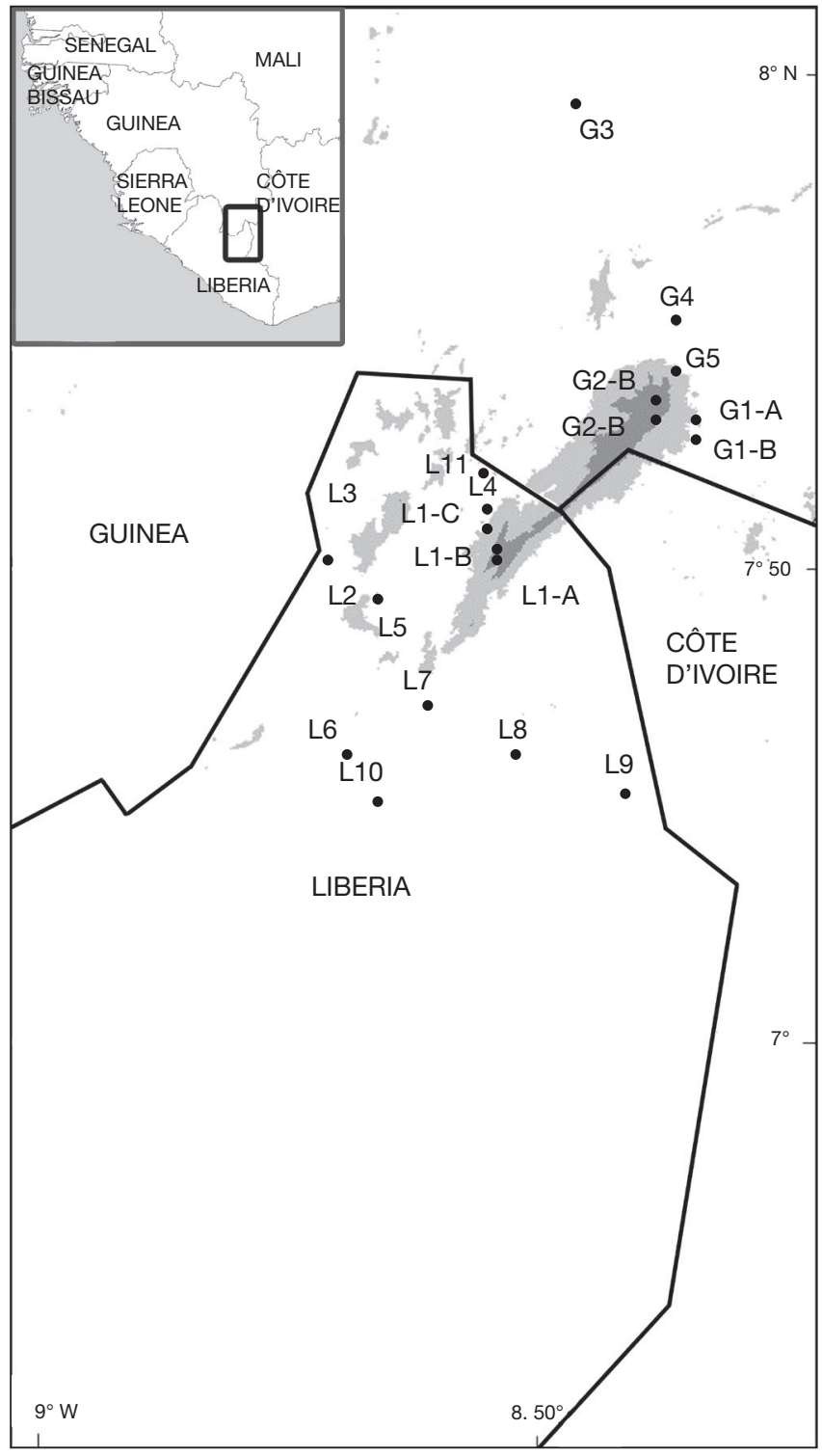

FIG. 1. - Detail of the trapping localities at Mount Nimba with respect to elevation. Sampling sites are shown in black circles. Light and dark grey shading refer to areas above $600 \mathrm{~m}$ and $1000 \mathrm{~m}$, respectively. Names of localities used in this work as follows: G, Guinea; L, Liberia, Gbié: G1-A, B; Gouan: G2-A, B; Seringbara: G3; Gblayougouma G4; Ziéla: G5; East Nimba Nature Reserve L1-A B, C; Bentor: L2; Bonlah: L3; Yekepa: L4; Tailings: L5; Camp4: L6; Liabala: L7; Gbapa: L8; Zolowee: L9; Grassfield: L10; Border (Yekepa): L11.

montane forests, secondary forests and agroecosystems from 400 to $1350 \mathrm{~m}$, as well as edaphic savannahs at altitudes of 500-600, 1200 and $1600 \mathrm{~m}$. (Figs 1; 2).

We used 180 Sherman traps baited with a mixture of wheat, oil, peanuts, dryfish and palm nuts to capture small mammals. Each line consisted of 20 to 40 traps at $5 \mathrm{~m}$ intervals. In addition, we used pitfall trap lines that consisted of 20 buckets (10 l) $5 \mathrm{~m}$ apart and linked with a plastic sheet drift fence $40 \mathrm{~cm}$ tall. Our total sampling effort was 4532 bucket-nights for the pitfalls and 9515 trap-nights for Shermans and tomahawks.

Animals were autopsied immediately after capture, following the guidelines of the American Society of Mammalogists (Sikes et al. 2016). We took the following standard external 
TABLE 1. - Description of all trapping devices and trapping sites sampled for shrews on Mount Nimba from 2008 to 2013. Abbreviations: ENNR, East Nimba Nature Reserve; PF, pitfall traps; $\mathrm{SH}$, Sherman live traps.

\begin{tabular}{|c|c|c|c|c|c|}
\hline Locality & Habitat & Elevation ( $m$ asl) & Latitude & Longitude & Trap type \\
\hline \multicolumn{6}{|l|}{ Guinea } \\
\hline \multirow{2}{*}{ Gbié } & Gallery forest & $552-621$ & 7.65 & -8.33 & SH \& PF \\
\hline & Savannah & $595-649$ & 7.63 & -8.33 & SH \& PF \\
\hline \multirow[t]{4}{*}{ Gouan } & Gallery forest & $1176-1212$ & 7.67 & -8.37 & $\mathrm{SH} \& \mathrm{PF}$ \\
\hline & Savannah & $1201-1236$ & 7.65 & -8.37 & $\mathrm{SH}$ \\
\hline & Altitude savannah & $1616-1642$ & 7.67 & -8.37 & $\mathrm{SH} \& \mathrm{PF}$ \\
\hline & Mare d'hivernage & & & & \\
\hline Seringbara & Secondary forest & $589-600$ & 7.97 & -8.45 & $\mathrm{SH} \& \mathrm{PF}$ \\
\hline Gblayougouma & Field, secondary forest and houses & 477 & 7.75 & -8.35 & SH \& PF \\
\hline Ziéla & Secondary and gallery forest & $477-581$ & 7.70 & -8.35 & $\mathrm{SH} \& \mathrm{PF}$ \\
\hline \multicolumn{6}{|l|}{ Liberia } \\
\hline \multirow[t]{3}{*}{ ENNR } & Secondary savannah & 1350 & 7.51 & -8.53 & $\mathrm{SH}$ \\
\hline & Primary mid- to high-elevation forest & $1065-1190$ & 7.52 & -8.53 & $\mathrm{PF}$ \\
\hline & Primary lowland rainforest & 690 & 7.54 & -8.54 & $\mathrm{SH}$ \\
\hline Bentor & Primary lowland rainforest & 420 & 7.51 & -8.70 & $\mathrm{PF}$ \\
\hline Bonlah & Disturbed forest edge & 450 & 7.57 & -8.66 & $\mathrm{SH}$ \\
\hline Yekepa & Swamp in peri-urban area & 515 & 7.56 & -8.54 & $\mathrm{PF}$ \\
\hline Tailings & Primary lowland forest & $475-495$ & 7.47 & -8.65 & $\mathrm{SH} \& \mathrm{PF}$ \\
\hline Camp4 & Gallery forest and swamp & $491-517$ & 7.44 & -8.66 & $\mathrm{SH} \& \mathrm{PF}$ \\
\hline Liabala & Secondary forest in front of the village & 478 & 7.40 & -8.58 & $\mathrm{PF}$ \\
\hline Gbapa N \& S & Secondary forest & $441-474$ & 7.46 & -8.49 & $\mathrm{SH} \& \mathrm{PF}$ \\
\hline Zolowee & Houses, Hevea Plantation & $458-473$ & 7.43 & -8.38 & $\mathrm{SH}$ \\
\hline Grassfield & Edaphic savannah, secondary forest & $427-518$ & 7.38 & -8.65 & $\mathrm{SH}$ \\
\hline Border (Yekepa) & Edaphic savannah, secondary forest & $542-569$ & 7.57 & -8.84 & $\mathrm{SH}$ \\
\hline
\end{tabular}

measurements: head and body length (HB), tail length $(\mathrm{T})$, ear length (E) and hindfoot length without claw (HF). We also recorded weight, sex, and reproductive state. Skulls were either prepared in the field, at the Muséum national d'Histoire naturelle (MNHN) in Paris, France, or in the Durban Natural Science Museum, Durban (DM), South Africa. Eleven craniodental measurements were taken adapted from Dippenaar (1977) and Hutterer \& Kock (2002) (Fig. 2) using a Mitutoyo caliper (Mitutoyo, Kawasaki, Japan) with a precision of $0.01 \mathrm{~mm}$. All specimens are housed in the mammal collections of the MNHN under catalogue numbers MNHN-ZM-2012-1051 to 2012-1205, 2014-899 to 2014-942 and at the DM under the numbers 13176-13204 (Appendices 1; 2; 3). Guinean species identification was based on an integrative taxonomic approach using morphological and molecular data (Jacquet et al. 2012). Based on genetic data the morphospecies $C$. muricauda could represent a complex of species (Jacquet et al. 2012), but pending revision of this species we take the conservative approach and consider it as a single species. The Liberian specimens were barcoded by two of us (A.L., J.G.B.) using cytochrome b partial sequences and identified using BLAST ("Basic Local Alignement Search Tool”) on the NCBI website (http://blast. ncbi.nlm.nih.gov/Blast.cgi; option "megablast").

\section{CyTOGENETIC ANALYSES}

Fifteen specimens were used for standard cytogenetic analysis, which were directly conducted in the field by Vladimir Aniskine and Morlaye Sylla (MNHN-ZM-2012-1051, MNHN-ZM-2012-1053, MNHN-ZM-2012-1069, MNHNZM-2012-1070 and MNHN-ZM-2012-1071 for C. buettikoferi; MNHN-ZM-2012-1076 and MNHN-ZM-2012-1077 for C. grandiceps; MNHN-ZM-2012-1087, MNHNZM-2012-1088 and MNHN-ZM-2012-1091 for C. jouvenetae; MNHN-ZM-2012-1153, MNHN-ZM-2012-1154, MNHN-ZM-2012-1156 and MNHN-ZM-2012-1164 for C. olivieri; and MNHN-ZM-2012-1168 and MNHNZM-2012-1171 for C. theresae). Metaphase chromosome preparations were obtained by the standard colchicine method following the protocol of Lee \& Elder (1980). We compared our data with those from other cytogenetic surveys in West Africa (Meylan 1967, 1971; de Hondt 1974; Meylan \& Vogel 1982; Lavrenchenko et al. 1997; Baskevitch et al. 1995; Schlitter et al. 1999).

\section{MORPHOMETRIC ANALYSES}

We performed univariate statistics on the external and craniodental measurements on all the newly collected specimens from Mount Nimba (Fig. 3; Appendices 1, 2). Means, standard deviations and ratios were calculated for weight and external measurements (HB, T, E and HF lengths) for 141 adult specimens in order to provide diagnostic characters between species and to quantify the morphometric variability within them. Similarly, we calculated standard statistics using eleven craniodental measurements (Fig. 3) (a: condyle-incisive length, b: nasal width, c: interorbital width, d: occipital greatest width, e: greatest maxillary width, f: upper tooth row length, g; height of the skull at M2 level, h: greatest braincase height, i: mandibular length, j: lower tooth row length, k: greatest length between extremities of the coronoid and angular processes) for 122 specimens, which had intact skulls.

We then tested for sex-and species-related differences using ANOVAs (Analysis of Variance) and MANOVAs (Multiple 

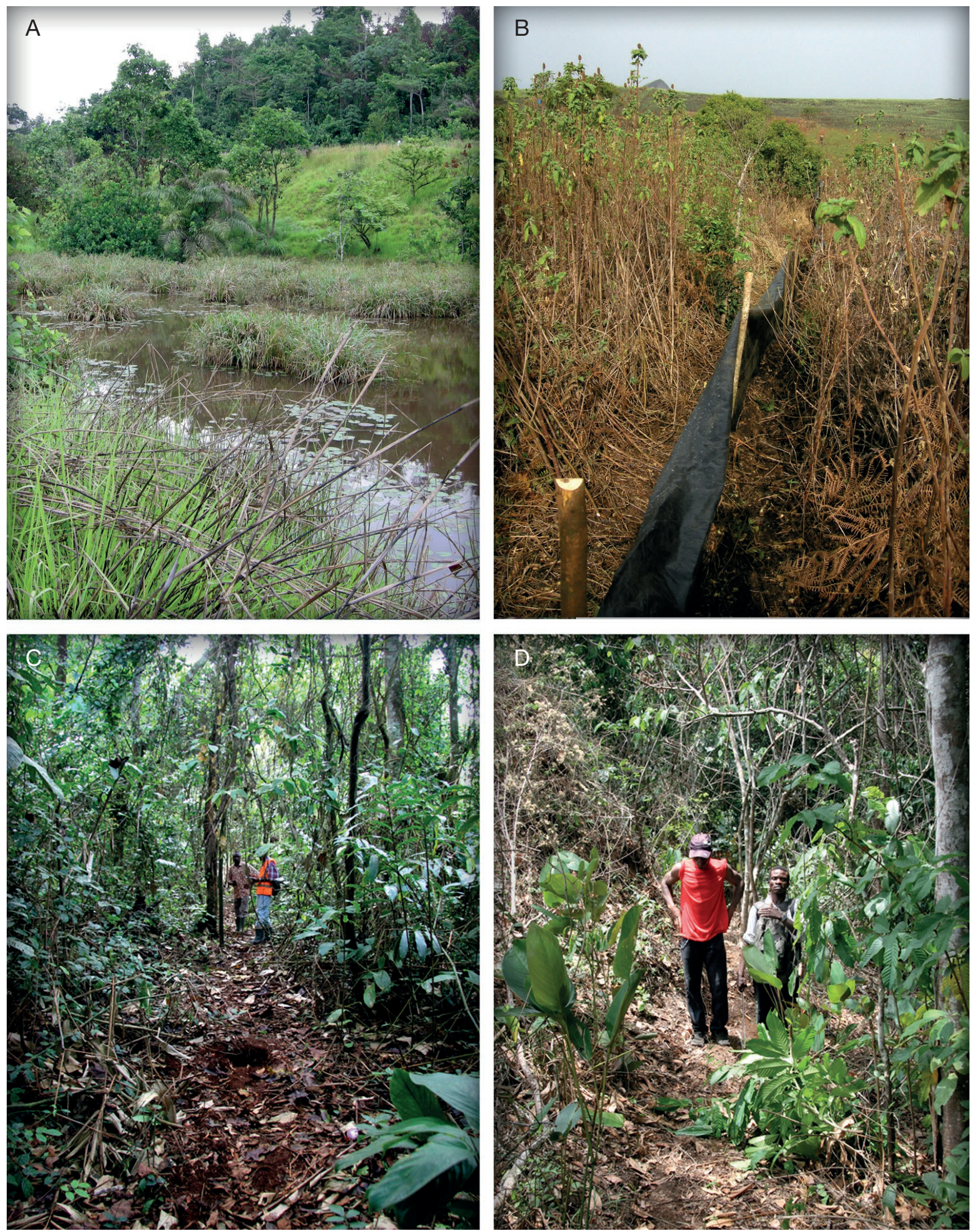

FIG. 2 - Examples of habitats where pitfall traps were placed on the Guinean and Liberian Nimba: A, gallery forest and swamp, camp 4 (Liberia); B, pitfall, altitude savannah with Loudetia kagerensis, Mare d'hivernage site (1642 m) (Guinea); C, pitfall, Selingbala (Guinea): mesophyllous secondary forest; D, pitfall, Gbie (Guinea): gallery forest with Parinari excelsa Sabine,1824, Carapa procera DC., 1824 and Pseudospondias microcarpa (A. Rich.) Engl., 1883, Maranthochloa purpurea (Ridl.) Milne-Redh. 

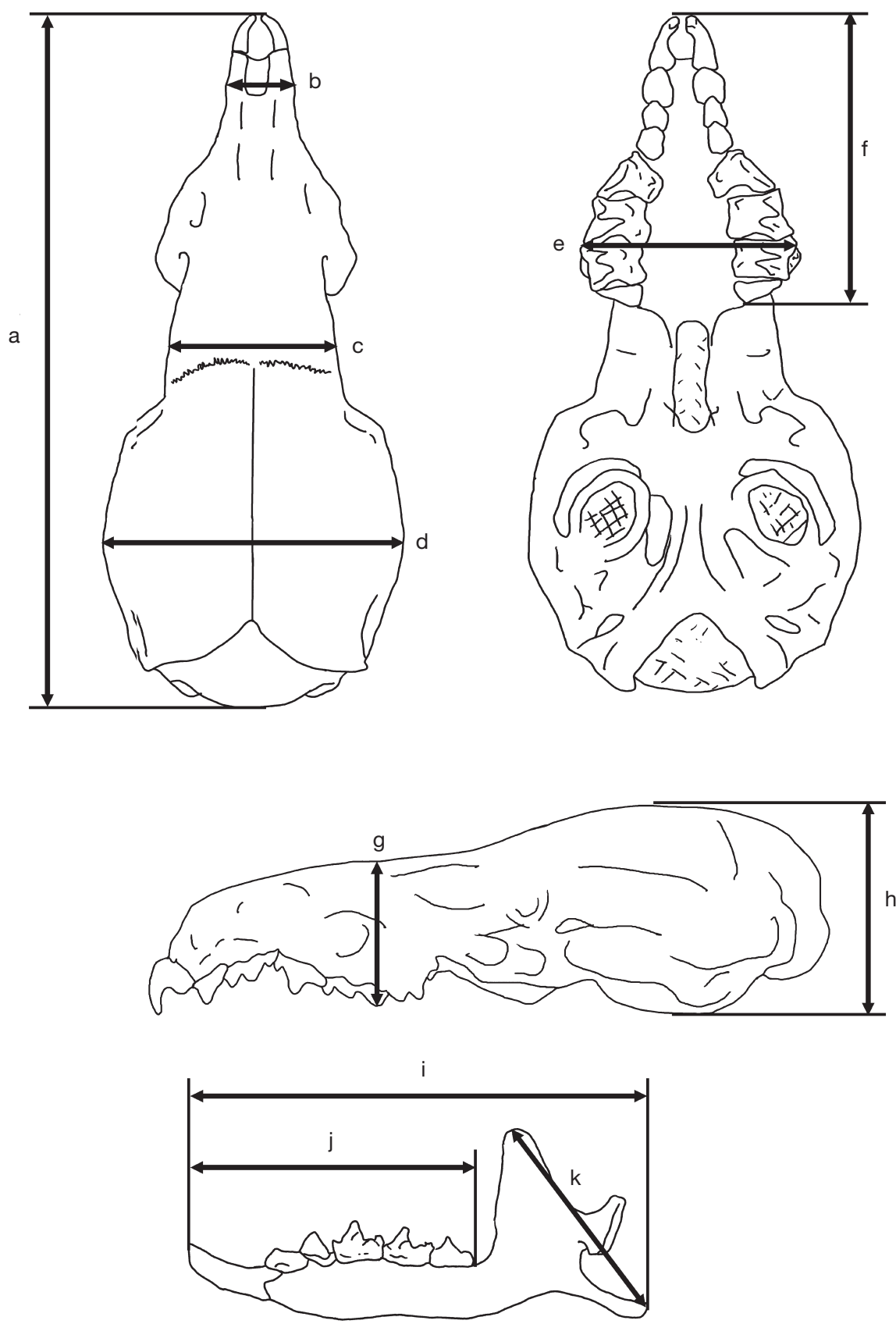

FIG. 3. - Craniodental measurements used for morphometric analyses adapted from Dippenaar (1977) and Hutterer \& Kock (2002): a, condyle-incisive length; b, nasal width; c, interorbital width; $\mathbf{d}$, occipital greatest width; e, greatest maxillary width; $\mathbf{f}$, upper tooth row length; $\mathbf{g}$, height of the skull at M2 level; $\mathbf{h}$, greatest braincase height; $\mathbf{i}$, mandibular length; $\mathbf{j}$, lower tooth row length; $\mathbf{k}$, greatest length between extremities of the coronoid and angular processes.

Analysis of Variance). Morphometric differences between species were also tested with CVA (Canonical Variate Analysis) using R version 2.9.0 (R Core Team, 2015) on log-transformed data. To obtain sufficient coverage for all our species, we added supplementary specimens from surrounding regions (Ziama Mt, Zouguepo, forest and savannahs of South eastern Guinea, i.e. Appendix 3) and Ivory Coast for the rarest species (C. nimbae, C. nimbasilvanus, C. douceti, C. eburnea).
Finally, we performed CVA on 41 specimens of C. buettikoferi, 12 C. denti, 5 C. eburnea, 7 C. nimbae, 15 C. muricauda, 39 C. obscurior, 19 C. olivieri, 19 C. grandiceps, 29 C. jouvenetae, 11 C. nimbasilvanus, and 39 C. theresae. We included intact (unbroken skulls) type series specimens described by Heim de Balsac (1958) from our region (Appendix 3). Nearly all of the specimens that we used for morphometric analyses have also been molecularly barcoded. 
TABLE 2. - Seasonal trapping success in localities and habitats where pitfall trap lines were installed. The habitat and elevation of each site is also presented. Abbreviation: ENNR, East Nimba Nature Reserve.

\begin{tabular}{|c|c|c|c|c|c|c|}
\hline \multirow[b]{2}{*}{ Locality } & \multirow[b]{2}{*}{ Habitat } & \multirow{2}{*}{$\begin{array}{c}\text { Elevation } \\
\text { (m asl) }\end{array}$} & \multicolumn{2}{|c|}{ Trapping effort (trap-nights) } & \multicolumn{2}{|c|}{ Trapping success (specimens/trap nights * 100) } \\
\hline & & & Dry season & Wet season & Dry season & Wet season \\
\hline Gbié & Savannah & 600 & 240 & 322 & 2.92 & 7.14 \\
\hline Gouan & Forest & $1000-1200$ & 480 & 140 & 3.96 & 5 \\
\hline Ziéla & Forest, houses & 600 & 120 & - & 8.3 & - \\
\hline Mare d'hivernage & Savannah & 1600 & 120 & 140 & 7.5 & 14.3 \\
\hline Total Guinea & & & 1400 & 1152 & 3.71 & 5.12 \\
\hline ENNR & Forest, savannah & $690-1350$ & 130 & - & 3.08 & - \\
\hline Bentor & Forest & 420 & 60 & - & 18.33 & - \\
\hline Yekepa & Swamp & 515 & 60 & - & 1.67 & - \\
\hline Tailings & Forest & 500 & 100 & - & 3.00 & - \\
\hline Camp 4 & Swamp, forest & 500 & 280 & - & 3.57 & - \\
\hline Liebala & Forest & 478 & 240 & - & 7.5 & - \\
\hline Gbapa & Forest & 500 & 60 & - & 5 & - \\
\hline Total Liberia & & & 1980 & - & 5.34 & - \\
\hline
\end{tabular}

TABLE 3. - Seasonal trapping success in localities and habitats where Sherman traps were installed. The habitat and elevation of each site is also presented. Abbreviation: ENNR, East Nimba Nature Reserve.

\begin{tabular}{|c|c|c|c|c|c|c|}
\hline \multirow[b]{2}{*}{ Locality } & \multirow[b]{2}{*}{ Habitat } & \multirow{2}{*}{$\begin{array}{l}\text { Elevation } \\
\text { (m asl) }\end{array}$} & \multicolumn{2}{|c|}{ Trapping effort (trap nights) } & \multicolumn{2}{|c|}{ Trapping success (specimens/trap nights * 100) } \\
\hline & & & Dry season & Wet season & Dry season & Wet season \\
\hline Gbié & Gallery forest, savannah & 600 & 550 & 1140 & 1.09 & 0.7 \\
\hline Gouan & Forest & 1200 & 840 & 1025 & 0.12 & 0.39 \\
\hline Mare d'hivernage & Savannah & 1600 & 450 & 930 & 1.11 & 0.54 \\
\hline Seringbara & Forest & 600 & 1000 & 1090 & 0.0 & 0 \\
\hline Gblayougouma & Village & 500 & 222 & - & 0 & - \\
\hline Ziéla & Gallery Forest & 500 & 1209 & 30 & 0.5 & 3.33 \\
\hline Total Guinea & & & 4271 & 4215 & 0.42 & 0.43 \\
\hline ENNR & Forest & 600 & 88 & - & 2.27 & - \\
\hline ENNR & Forest & $1000-1300$ & 88 & - & 1.14 & - \\
\hline Bonlah & Forest & 450 & 44 & - & 2.27 & - \\
\hline Tailings & Forest & 500 & 215 & - & 2.79 & - \\
\hline Zolowee & Houses & 500 & 90 & - & 2.22 & - \\
\hline Grassfield & Savannah & 600 & 144 & - & 2.78 & - \\
\hline Gbapa & Swamp, forest & 500 & 180 & - & 1.67 & - \\
\hline Camp4 & Forest & 500 & 90 & & 2.22 & - \\
\hline Border, Yekepa & Forest, savannah & 500 & 90 & - & 2.36 & - \\
\hline Total Liberia & & & 1029 & - & 2.33 & - \\
\hline
\end{tabular}

\section{CONSTRUCTION OF AN IDENTIFICATION KEY}

To assist in the identification of shrew species occurring on Mount Nimba we developed a dichotomous key that could be usable in the field and could work on live animals. Therefore, we used, as far as possible, external characters visible or measurable in the field. However, in a few instances reference to craniodental features was necessary to ensure accurate identifications. To take intraspecific variability into account, especially when few specimens of a species, like $C$. douceti, C. eburnea and C. nimbasilvanus, were collected, we used additional shrew specimens of the same species housed in the collections of the Muséum national d'Histoire naturelle, among which were 10 type specimens described from Mount Nimba and neighbouring regions (Appendix 3).

\section{ABBREVIATIONS}

\section{Institutions}

DM Durban Natural Science Museum, Durban;

MNHN Muséum national d'Histoire naturelle, Paris.

$\begin{array}{ll}\text { Measurements } & \\ \mathrm{HB} & \text { Head and body length; } \\ \mathrm{TL} & \text { tail length; } \\ \mathrm{HF} & \text { hindfoot length; } \\ \mathrm{E} & \text { ear length; } \\ \mathrm{TL} / \mathrm{HB} & \text { ratio of tail length on head and body length; } \\ \mathrm{W} & \text { weight. }\end{array}$

\section{RESULTS}

TRAPPING RESULTS AND ECOLOGICAL DATA

Trapping success per locality and device for both the dry and wet seasons are presented in Tables 2 and 3. In Guinea, with pitfall traps, the overall trapping success was better in the wet than in the dry season. In the case of the edaphic and high-altitude savannahs (600 and 1600 m; Gbié and Mare d'hivernage), the trapping success was more than doubled between the dry and wet season (Table 2). There was great variability in capture success rate between pitfall sites, with the 
TABLE 4. - Diversity, relative abundance, and habitats of shrew species from Guinean and Liberian sides of Mount Nimba. Abbreviations: NI, total number of individuals; RA, relative abundance.

\begin{tabular}{|c|c|c|c|c|c|c|}
\hline Species & $\begin{array}{l}\text { Guinea } \\
\text { NI }\end{array}$ & $\begin{array}{l}\text { Guinea } \\
\text { RA (\%) }\end{array}$ & $\begin{array}{l}\text { Liberia } \\
\text { NI }\end{array}$ & $\begin{array}{l}\text { Liberia } \\
\text { RA (\%) }\end{array}$ & Habitat & $\begin{array}{l}\text { Altitude } \\
\text { (m asl) }\end{array}$ \\
\hline \multirow[t]{2}{*}{$\begin{array}{l}\text { Crocidura obscurior Heim } \\
\text { de Balsac, } 1958\end{array}$} & 36 & 23.5 & 7 & 9.6 & $\begin{array}{l}\text { Lowland gallery forest, secondary } \\
\text { forest, mountane forest }\end{array}$ & $400-600,1200$ \\
\hline & & & & & Savannah & $400-600,1600$ \\
\hline $\begin{array}{l}\text { Crocidura sp. (obscurior/ } \\
\text { eburnea) }\end{array}$ & 0 & 0.0 & 5 & 6.8 & $\begin{array}{l}\text { Lowland secondary forest, } \\
\text { gallery forest }\end{array}$ & $400-600$ \\
\hline $\begin{array}{l}\text { C. eburnea Heim de } \\
\text { Balsac, } 1958\end{array}$ & 0 & 0.0 & 12 & 16.4 & Lowland gallery forest & $400-600$ \\
\hline \multirow[t]{2}{*}{$\begin{array}{l}\text { C. jouvenetae Heim de } \\
\text { Balsac, } 1958\end{array}$} & 23 & 15.0 & 8 & 11 & $\begin{array}{l}\text { Lowland gallery forest, secondary } \\
\text { forest, mountane forest }\end{array}$ & 600,1200 \\
\hline & & & & & Lowland gallery forest, savannah & 600,1600 \\
\hline $\begin{array}{l}\text { C. theresae Heim de } \\
\text { Balsac, } 1968\end{array}$ & 23 & 15.0 & 4 & 5.5 & $\begin{array}{l}\text { Lowland gallery forest } \\
\text { Savannah }\end{array}$ & $\begin{array}{l}600 \\
600-1200,1600\end{array}$ \\
\hline \multirow[t]{2}{*}{$\begin{array}{l}\text { C. buettikoferi Jentink, } \\
1888\end{array}$} & 22 & 14.4 & 9 & 12.3 & $\begin{array}{l}\text { Lowland gallery forest, secondary } \\
\text { forest, mountane forest }\end{array}$ & $400-600,1200$ \\
\hline & & & & & Savannah & 1600 \\
\hline \multirow[t]{2}{*}{ C. olivieri (Lesson, 1827) } & 13 & 8.5 & 15 & 20.5 & $\begin{array}{l}\text { Bush, fallow, lowland gallery forest, } \\
\text { secondary forest, mountane forest }\end{array}$ & $400-600,1200$ \\
\hline & & & & & Savannah & 600 \\
\hline \multirow[t]{2}{*}{$\begin{array}{l}\text { C. grandiceps Hutterer, } \\
1983\end{array}$} & 11 & 7.2 & 5 & 6.8 & \multicolumn{2}{|c|}{$\begin{array}{l}\text { Houses, swamp, lowland gallery forest, 400-600, } 1200 \\
\text { secondary forest, mountane forest }\end{array}$} \\
\hline & & & & & Edaphic savannah & 600 \\
\hline C. muricauda (Miller, 1900) & 7 & 4.6 & 5 & 6.9 & $\begin{array}{l}\text { Mountain gallery forest, lowland } \\
\text { gallery forest, savannah }\end{array}$ & $600-1200$ \\
\hline $\begin{array}{l}\text { C. douceti Heim de Balsac, } \\
1958\end{array}$ & 1 & 0.6 & 0 & 0.0 & Lowland secondary forest & 600 \\
\hline $\begin{array}{l}\text { C. nimbasilvanus Hutterer, } \\
2003\end{array}$ & 1 & 0.6 & 1 & 1.4 & Lowland forest, gallery forest & $400-600$ \\
\hline \multirow[t]{2}{*}{$\begin{array}{l}\text { Suncus megalura (Jentink, } \\
\text { 1888) }\end{array}$} & 16 & 10.6 & 2 & 2.7 & $\begin{array}{l}\text { Lowland forest, gallery forest, } \\
\text { secondary forest, mountane forest }\end{array}$ & $400-1200$ \\
\hline & 153 & 100 & 73 & 100 & Savannah & 600,1600 \\
\hline
\end{tabular}

best results from primary lowland forest at Bentor, which was alongside a medium-sized river, and in the Mare d'hivernage (high-altitude savannah). With Sherman traps, capture success was always low and similar in the dry and wet seasons, in the different habitats of Guinea (Table 3). The best results were obtained in gallery forests at $600 \mathrm{~m}$ (Ziela) and in the high-altitude savannah at $1600 \mathrm{~m}$ (Mare d'hivernage). No specimens were trapped in houses in the Guinean side. In Liberia best trapping success was obtained in Tailings (lowland forest) and Grassfield (edaphic savannah). A single individual of C. grandiceps was found in a house in Zolowee village in Liberia in 2013.

Of the 226 specimens captured in this study, 209 (92\%) belong to the genus Crocidura and $17(8 \%)$ to the genus Suncus Ehrenberg, 1832 (Table 4). The genus Crocidura was represented by 10 species, and Suncus by one species. We collected mostly the same species on both sides of Mount Nimba with the exceptions of C. eburnea (Liberian side only) and $C$. douceti (Guinean side only). We did not trap $C$. nimbae, which was previously recorded from Mount Nimba by Heim de Balsac (1958). Suncus megalura (Jentink, 1888) was trapped in both Liberia and Guinea. In the Guinean side, the most abundant species in our sampling was C. obscurior, which represented $23.5 \%$ of all captured specimens. Crocidura buettikoferi, $C$. theresae and C. jouvenetae each represented about $15 \%$ of all captures.
We trapped one specimen of $C$. douceti and two C. nimbasilvanus. In Liberia, the most abundant species was $C$. olivieri (20.3\%), followed by C. eburnea and C. obscurior (16.4\%), C. buettikoferi (12.2\%) and C. jouvenetae (10.3\%). A few specimens of $C$. theresae, C. grandiceps, C. muricauda and C. nimbasilvanus were also captured.

The lowland primary and gallery forests between 400 and $800 \mathrm{~m}$ harboured all shrew species that we recorded from Mount Nimba (11 species, two genera) (Table 5; Appendices $4 ; 5)$. By comparison, only seven species (of both genera) were recorded in montane forests between 1000 and $1200 \mathrm{~m}$ (S. megalura, C. muricauda, C. grandiceps, C. olivieri, C. buettikoferi, C. jouvenetae, C. obscurior) and five species (of both genera) were encountered in high-altitude edaphic savannahs at 1200-1600 m (S. megalura, C. theresae, C. jouvenetae, C. obscurior, C. buettikoferi). The lowland edaphic savannah hosted S. megalura, C. muricauda, C. grandiceps, C. olivieri, $C$. theresae, C. jouvenetae and $C$. obscurior. Among the species restricted to lowland primary, secondary, and gallery forests were $C$. nimbasilvanus, $C$. douceti and C. eburnea.

\section{KARYOTYPES}

The three males and two females of $C$. buettikoferi displayed the same karyotype with diploid number $2 n=52$ and fundamental number of autosomes $\mathrm{NFa}=66$ (Fig. 4A). The autosomal set comprised three pairs of small meta-submetacentric 


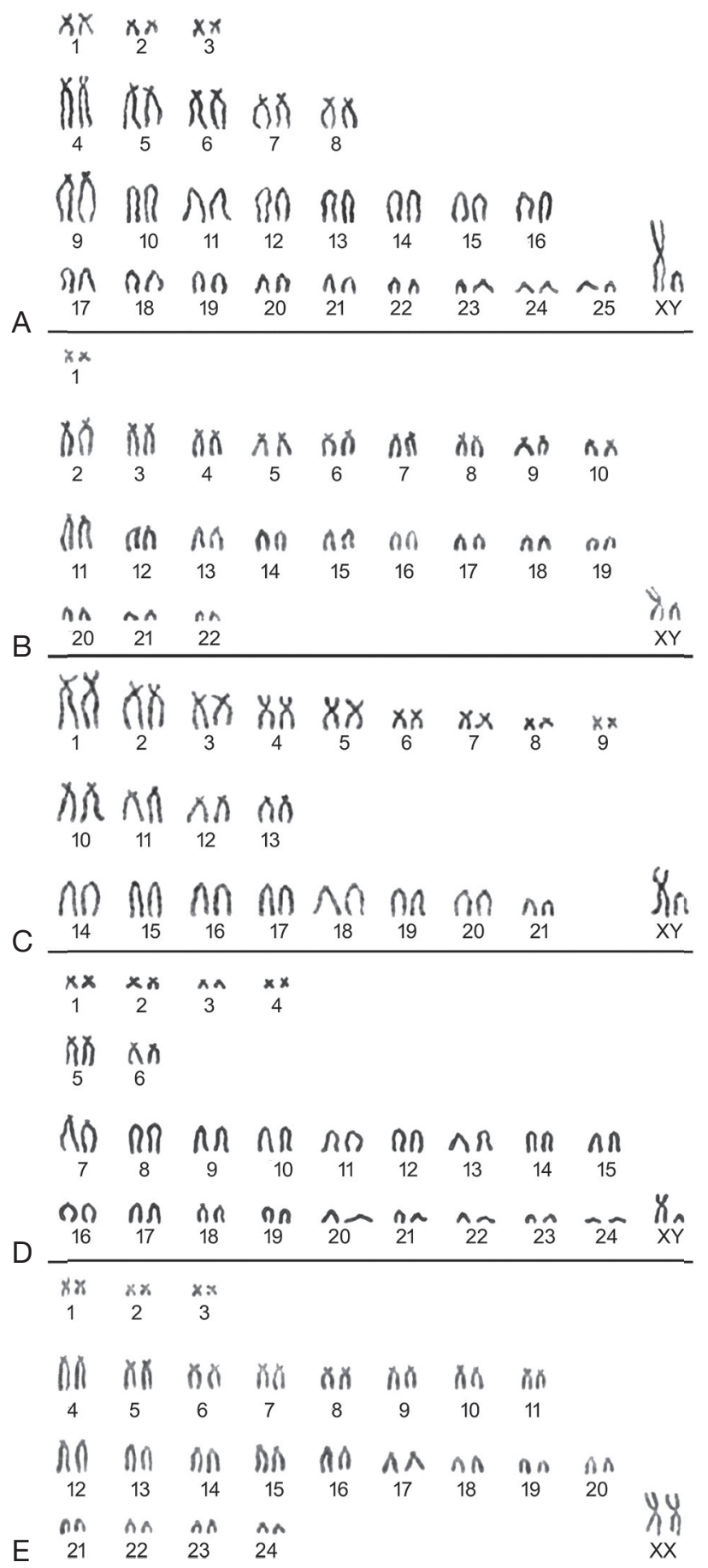

FIG. 4. - Standard karyotypes from Mount Nimba shrews: A, male C. buettikoferi Jentink, $1888 \mathrm{MNHN}-\mathrm{ZM}-2012-1071,2 \mathrm{n}=52, \mathrm{NFa}=66$; $\mathbf{B}$, male $\mathrm{C}$. grandiceps Hutterer, 1983 MNHN-ZM-2012-1077, 2n = 46, NFa = 64; C, male C. jouvenetae Heim de Balsac, 1958 MNHN-ZM-2012-1091, $2 n=44$, NFa = 68; $\mathbf{D}$, male C. olivieri (Lesson, 1827) MNHN-ZM-2012-1164, 2n = 50, NFa = 60; E, female C. theresae Heim de Balsac, 1968 MNHN-ZM-2012-1171, 2n=50, NFa $=70$.

$\left(1^{\text {st }} 3^{\text {rd }}\right)$, five pairs of subtelocentric $\left(4^{\text {th }}-8^{\text {th }}\right)$ and 17 pairs of acrocentric chromosomes ( $\left.9^{\text {th }}-25^{\text {th }}\right)$ decreasing in size. The $\mathrm{X}$ and $\mathrm{Y}$ chromosomes were constituted respectively of the largest metacentric and an acrocentric element similar in size to the $19^{\text {th }}$ pair of autosomes.
The two males of $C$. grandiceps had $2 \mathrm{n}=46$ and $\mathrm{NFa}=64$ (Fig. 4B). The karyotype comprised one pair of small metacentric (1st), nine pairs of subtelocentric $\left(2^{\text {nd }}-10^{\text {th }}\right)$ and 12 pairs of acrocentric chromosomes (11 th-22nd) decreasing in size. The $\mathrm{X}$ was a large-sized metacentric chromosome and the $\mathrm{Y}$ was acrocentric and similar in size to the $17^{\text {th }}$ pair of autosomes.

The three $C$. jouvenetae specimens displayed identical karyotypes with $2 \mathrm{n}=44$ and $\mathrm{NFa}=68$ (Fig. 4C). The autosomal set comprises nine pairs of large to small metacentric and submetacentric chromosomes (1st-9th), four subtelocentric pairs $\left(10^{\text {th }}-13^{\text {th }}\right)$ and eight acrocentric pairs $\left(14^{\text {th }}-21^{\text {st }}\right)$. The $X$ and $Y$ chromosomes were easily recognizable and represented a large-sized metacentric and an acrocentric slightly higher in size than the $21^{\text {st }}$ pair of autosomes, respectively.

The three males and the female of $C$. olivieri were characterized by $2 \mathrm{n}=50$ and $\mathrm{NFa}=60$ (Fig. 4D). The karyotypes consisted of four small meta-submetacentric pairs $\left(1^{\text {st }}-4^{\text {th }}\right)$, two medium-sized subtelocentric pairs $\left(5^{\text {th }}-6^{\text {th }}\right)$ and 18 acrocentric pairs of chromosomes $\left(7^{\text {th }}-24^{\text {th }}\right)$ decreasing in size. The $\mathrm{X}$ and $\mathrm{Y}$ chromosomes were metacentric and small acrocentric, respectively.

The male and the female of $C$. theresae displayed the same karyotype with $2 \mathrm{n}=50$ and $\mathrm{NFa}=70$ (Fig. 4E). The karyotype contained three pairs of small bi-armed autosomes similar in size ( $\left.1^{\text {st }}-3^{\text {rd }}\right)$, eight subtelocentric pairs $\left(4^{\text {th }}-11^{\text {th }}\right)$ and 13 acrocentric pairs $\left(12^{\text {th }}-24^{\text {th }}\right)$ progressively decreasing in size. The $\mathrm{X}$ chromosome was a large-sized metacentric and the $\mathrm{Y}$ was acrocentric and similar in size to the $21^{\text {st }}$ pair of autosomes (data not shown).

\section{MORPHOMETRIC DATA}

Shrew species occurring on Mount Nimba differed in external body measurements $(\mathrm{F}=15.596, \mathrm{P}<0.001)$, in body weight $(\mathrm{F}=135.8, \mathrm{P}<0.001)$ and in craniodental measurements $(\mathrm{F}=3.7812, \mathrm{P}<0.001)$. Some sexual dimorphism was detected $(\mathrm{F}=1.8896, \mathrm{P}=0.120, \mathrm{~F}=0.661, \mathrm{P}=0.120$ and $\mathrm{F}=1.9245$, $\mathrm{P}=0.070$, respectively), but we preferred to keep male and female specimens pooled for the remaining analyses due to relatively low sample sizes.

The CVA performed on the four body measurements (Fig. 5) showed that most of the variability was recovered on axis 1 , representing $70.5 \%$ of the total variability (Appendices 4; 5). The highest loadings on axis 1 were HB, HF, E. Axis 2 represented $26 \%$ of the variability and the highest loading was TL (Appendix 4). The CVA on external measurements allowed discrimination of $C$. muricauda and $S$. megalura from all other species along the second axis with regards to their long tail length (Fig. 5). Crocidura douceti was also partially differentiated along axis 2. Along axis 1 we observed an opposition between the smallest species (negative side of the axis) C. obscurior, C. eburnea, C. douceti and the largest (positive side) C. nimbasilvanus, relatively well differentiated. Mediumsized species like C. jouvenetae, C. theresae, C. buettikoferi, C. nimbae were situated in the centre of axis 1. Crocidura olivieri and $C$. grandiceps were two large-sized species, the former being larger than the latter. 
TABLE 5. - Means \pm standard deviations of standard external measurements for each collected shrew species from Mount Nimba only. Species are ordered by increasing weight.

\begin{tabular}{|c|c|c|c|c|c|}
\hline Species & Weight (g) & $\mathrm{HB}(\mathrm{mm})$ & TL (mm) & $\mathrm{HF}(\mathrm{mm})$ & TL/HB \\
\hline C. obscurior Heim de Balsac, 1958 & $3.8 \pm 0.6$ & $56.0 \pm 4.5$ & $33.7 \pm 2.5$ & $9.3 \pm 0.9$ & $0.61 \pm 0.08$ \\
\hline C. eburnea Heim de Balsac, 1958 & $3.9 \pm 0.9$ & $63.62 \pm 4.5$ & $36.15 \pm 3.4$ & $9.94+-0.4$ & $0.57 \pm 0.07$ \\
\hline C. douceti Heim de Balsac, 1958 & 4 & 103 & 57 & 11 & 0.55 \\
\hline C. muricauda (Miller, 1900) & $5.0 \pm 0.5-6$ & $63.5 \pm 5$ & $83.1 \pm 18.3$ & $11.8 \pm 0.7$ & $1.31 \pm-0.3$ \\
\hline S. megalura (Jentink, 1888) & $6.5 \pm 1.6$ & $68.8 \pm 5.3$ & $80.3 \pm 7.4$ & $14.3 \pm 0.9$ & $1.17 \pm 0.10$ \\
\hline C. jouvenetae Heim de Balsac, 1958 & $6.6 \pm 1.3$ & $70.3 \pm 5.9$ & $48.3 \pm 3.7$ & $11.4 \pm 1.3$ & $0.69 \pm 0.06$ \\
\hline C. theresae Heim de Balsac, 1968 & $12.3 \pm 2.4$ & $85.1 \pm 6.5$ & $52.3 \pm 4.1$ & $13.9 \pm 1.2$ & $0.62 \pm 0.07$ \\
\hline C. buettikoferi Jentink, 1888 & $14.4 \pm 3.2$ & $91.0 \pm 8.1$ & $59.0 \pm 4.2$ & $15.3 \pm 0.7$ & $0.65 \pm 0.06$ \\
\hline C. grandiceps Hutterer, 1983 & $18.7 \pm 6.1$ & $103.3 \pm 9.1$ & $74.1 \pm 11.0$ & $18.8 \pm 2.3$ & $0.72 \pm 0.11$ \\
\hline C. olivieri (Lesson, 1827) & $27.2 \pm 5.6$ & $119.6 \pm 8.0$ & $76.8 \pm 5.8$ & $19.3 \pm 1.4$ & $0.65 \pm 0.06$ \\
\hline C. nimbasilvanus Hutterer, 2003 & $48.5 \pm 51$ & $137-148$ & $117-120$ & $25-25$ & $0.81-0.85$ \\
\hline
\end{tabular}

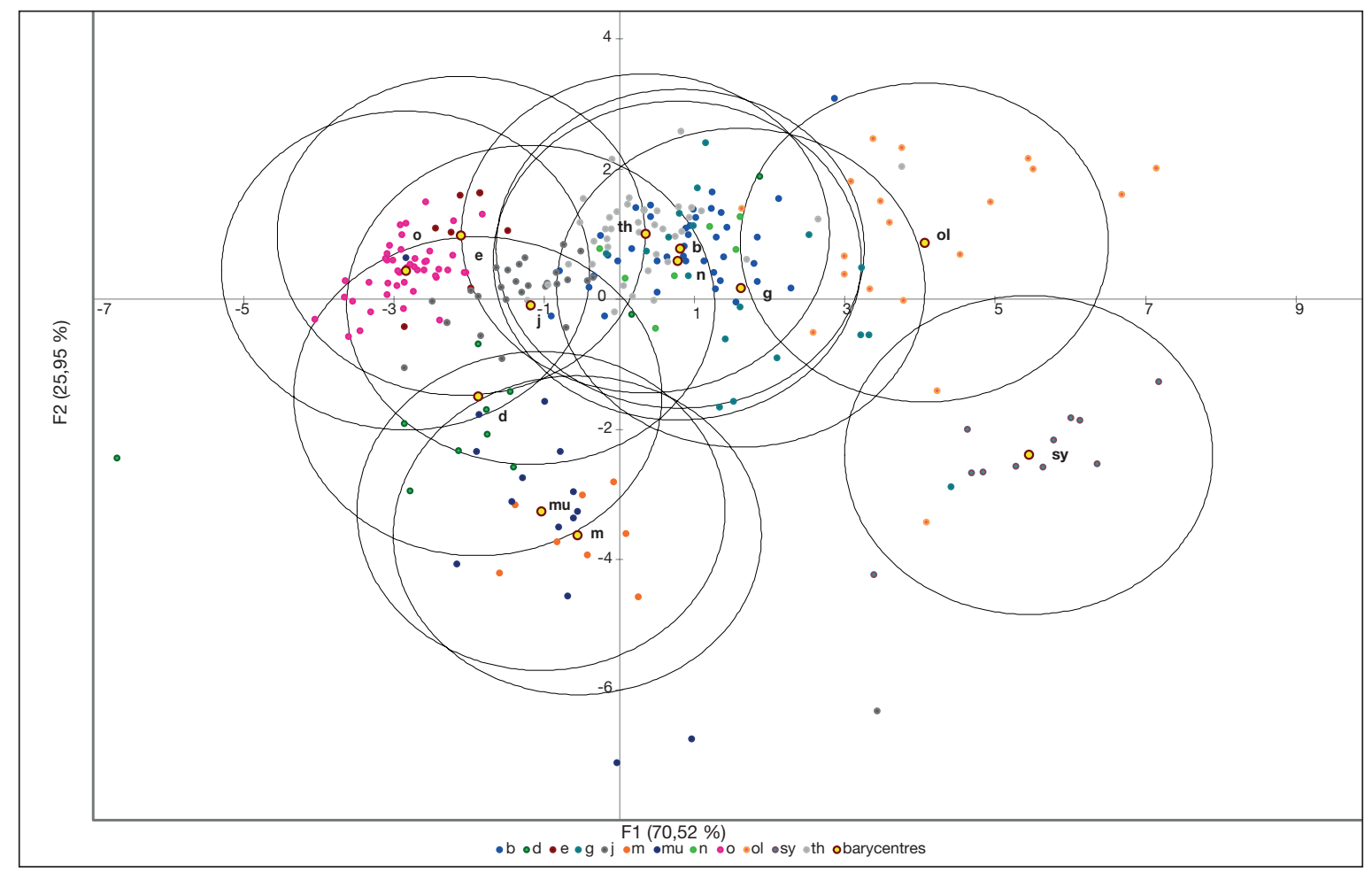

FIG. 5. - Plot between the two first axes of the CVA performed upon four external body measurements (head and body, tail, hindfoot, and tail lengths) for 252 shrew specimens from Mount Nimba, Ziama and surrounding areas. Each species is represented by a color dot. Yellow dots indicate class barycenter and ellipses at 0.05\% confidence; b, C. buettikoferi Jentink, 1888; d, C. douceti Heim de Balsac, 1958; e, C. eburnea Heim de Balsac, 1958; g, C. grandiceps Hutterer, 1983; j, C. jouvenetae Heim de Balsac, 1958; C. muricauda (Miller, 1900); mu, S. megalura (Jentink, 1888); n, C. nimbae Heim de Balsac, 1956; o, C. obscurior Heim de Balsac, 1958; ol, C. olivieri (Lesson, 1827); sy, C. nimbasilvanus Hutterer, 2003; t, C. theresae Heim de Balsac, 1968.

Calculation of means and standard deviations for external body measurements (Table 5) also showed that most values did not overlap between species, which appeared to be size calibrated when considering only the Mount Nimba specimens. A continuum from the smallest to the largest species was observed, each being replaced in turn by another slightly larger species. The smallest species were C. obscurior, C. eburnea and C. douceti that were followed by five slightly larger species $C$. jouvenetae, C. muricauda, S. megalura, C. theresae and C. buettikoferi. Next were $C$. grandiceps, $C$. olivieri and $C$. nimbasilvanus, which were the largest species. Crocidura muricauda and $S$. megalura are further differentiated from all other species by their long tails, where tail to head-body ratio is greater than 1.0 (Table 5).
The plot between the two first axes of the CVAs and on the 11 cranio-dental measurements (Fig. 5) allowed good discrimination between the 11 species of our data set (Fig. 6, Appendices 6; 7). Most of the variability was recovered on axis 1 (86.5\%). All variables were highly correlated with this axis, indicating a size relationship (Appendix 6). On axis 2 (5.5\%), the best correlated variables were nasal width (b), occipital height $(\mathrm{h})$ and molar height (g). Crocidura nimbae could be distinguished from all other species on this. The three smallest shrews ( $C$. obscurior, C. eburnea, and $C$. douceti) can be distinguished on the negative side of axis 1 , with the mean-sized species $C$. megalura + C. muricauda + C. jouvenetae, followed by the medium-large species $C$. theresae $+C$. grandiceps $+C$. buettikoferi and finally 


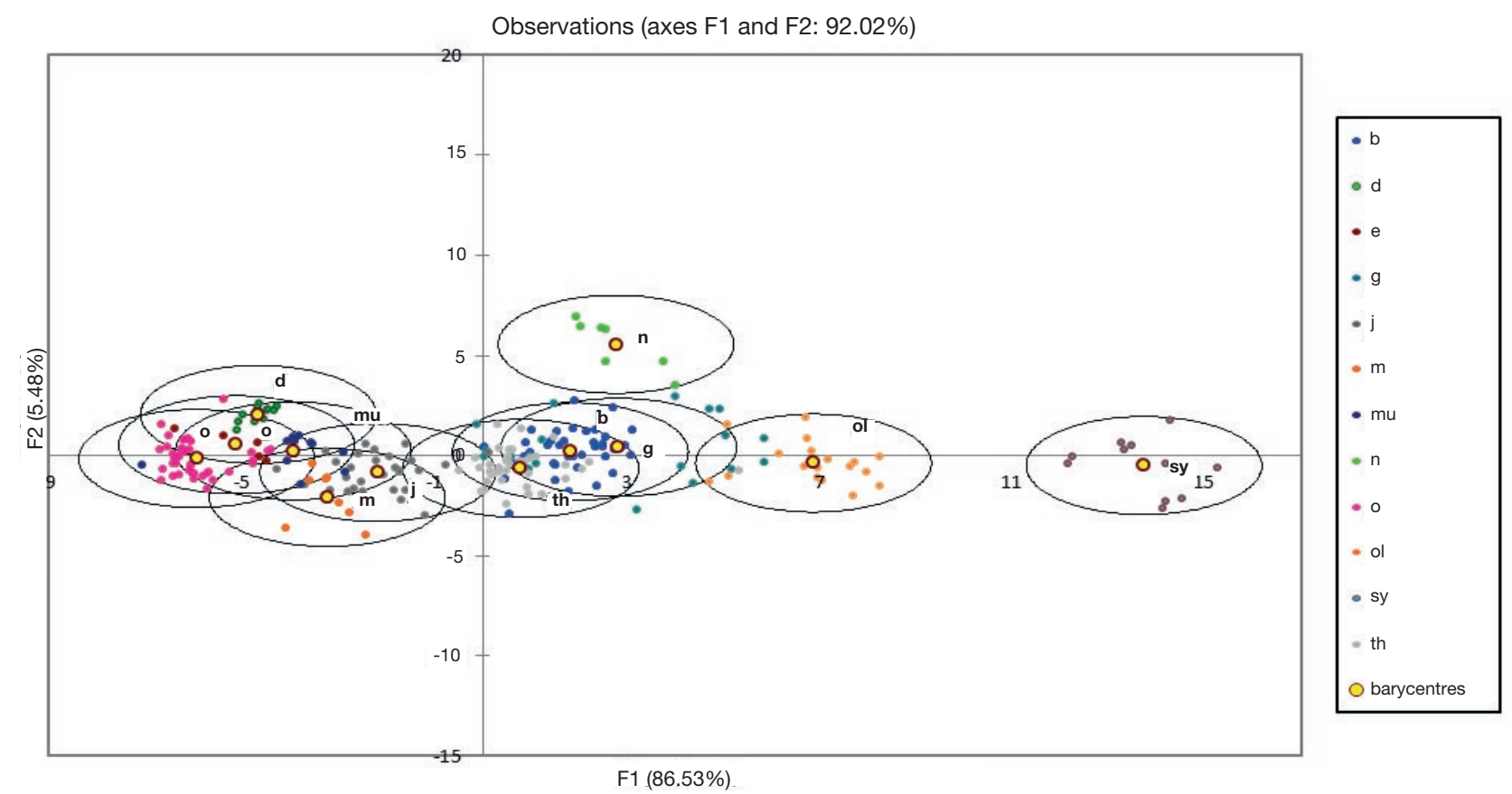

FIG. 6. - Plot between the two first axes of the CVA performed upon 11 craniodental measurements for 244 shrew specimens from Mount Nimba, Ziama and surroundings. Each species is represented by a color dot. In yellow class barycenter and ellipses at $0.05 \%$ confidence: b, Crocidura buettikoferi Jentink, 1888 ; d, C. douceti Heim de Balsac, 1958; e, C. eburnea Heim de Balsac, 1958; g, C. grandiceps Hutterer, 1983; j, C. jouvenetae Heim de Balsac, 1958, C. muricauda (Miller, 1900); mu, S. megalura (Jentink, 1888); n, C. nimbae Heim de Balsac, 1956, o, C. obscurior Heim de Balsac, 1958; ol, C. olivieri (Lesson, 1827); sy, C. nimbasilvanus Hutterer, 2003; t, C. theresae Heim de Balsac, 1968.

TABLE 6. - Means and standard deviations for craniodental measurements on sequenced specimens from Mount Nimba based on newly recovered specimens. All measurements in millimeters. All measurements by CD. Abbreviations for measurements see Figure 2 . For authorships of the species, see Table 5.

\begin{tabular}{|c|c|c|c|c|c|c|c|c|c|c|c|}
\hline Species & $\mathbf{a}$ & b & C & d & e & $\mathbf{f}$ & g & h & i & j & $\mathbf{k}$ \\
\hline C. obscurior & $15.7 \pm 0.7$ & $1.9 \pm 0.2$ & $3.8 \pm 0.2$ & $7 \pm 0.4$ & $4.7 \pm 0.2$ & $6.8 \pm 0.3$ & $3.3 \pm 0.2$ & $4.2 \pm 0.3$ & $9.7 \pm 0.5$ & $6.3 \pm 0.4$ & $4.1 \pm 0.4$ \\
\hline C. eburnea & $16.4 \pm 1.1$ & $2.0 \pm 0.3$ & $3.8 \pm 0.2$ & $7.2 \pm 0.5$ & $5 \pm 0.4$ & $7.6 \pm 0.4$ & $3.4 \pm 0.1$ & 4.9 & $10.4 \pm 0.4$ & $6.9 \pm 0.4$ & $4.4 \pm 0.8$ \\
\hline C. douceti & 17.2 & 2 & 3.72 & 7.5 & 4.8 & 7.55 & 3.7 & 4.8 & 10.9 & 6.9 & 4.2 \\
\hline C. muricauda & $18.5 \pm 1.3$ & $2.1 \pm 0.2$ & $3.8 \pm 0.4$ & $7.7 \pm 0.6$ & $5.2 \pm 0.4$ & $7.8 \pm 0.6$ & $3.9 \pm 0.5$ & $5.1 \pm 0.8$ & $11 \pm 0.8$ & $7 \pm 0.6$ & $4.5 \pm 0.4$ \\
\hline S. megalura & $18.7 \pm 0.3$ & $2.3 \pm 0.2$ & $4.4 \pm 0.2$ & $7.9 \pm 0.2$ & $5.6 \pm 0.2$ & $7.9 \pm 0.3$ & $4.3 \pm 0.2$ & $5.3 \pm 0.3$ & $11.3 \pm 0.5$ & $7.2 \pm 0.3$ & $5.4 \pm 0.3$ \\
\hline C. jouvenetae & $20 \pm 1.1$ & $2.4 \pm 0.2$ & $4.2 \pm 0.3$ & $8 \pm 0.6$ & $6.1 \pm 0.4$ & $8.8 \pm 0.6$ & $4.1 \pm 0.4$ & $4.7 \pm 0.4$ & $12.6 \pm 08$ & $8.2 \pm 0.5$ & $5.6 \pm 0.7$ \\
\hline C. theresae & $22.5 \pm 0.5$ & $2.6 \pm 0.3$ & $5.0 \pm 0.2$ & $9.3 \pm 0.4$ & $7 \pm 0.3$ & $9.9 \pm 0.3$ & $5.0 \pm 0.4$ & $5.9 \pm 0.4$ & $14.2 \pm 0.4$ & $9.1 \pm 0.3$ & $6.2 \pm 0.5$ \\
\hline C. buettikoferi & $24 \pm 0.8$ & $2.7 \pm 0.2$ & $5.4 \pm 0.4$ & $9.8 \pm 0.6$ & $7.3 \pm 0.3$ & $10.6 \pm 0.3$ & $4.9 \pm 0.3$ & $6.2 \pm 0.5$ & $15.6 \pm 0.6$ & $9.9 \pm 0.4$ & $7 \pm 0.5$ \\
\hline C. grandiceps & $26.7 \pm 2$ & $2.9 \pm 03$ & $5.6 \pm 0.4$ & 10. \pm 0.9 & $7.9 \pm 0.8$ & $12.1 \pm 1.3$ & $5.8 \pm 0.8$ & $6.5 \pm 0.7$ & $17.2 \pm 1.7$ & $10.4 \pm 1.7$ & $7.8 \pm 1.7$ \\
\hline C. olivieri & $29.9 \pm 1.0$ & $3.4 \pm 0.4$ & $5.7 \pm 0.2$ & $11.3 \pm 0.4$ & $9.1 \pm 0.4$ & $13.6 \pm 0.4$ & $6.2 \pm 0.5$ & $7 \pm 0.4$ & $19.6 \pm 07$ & $12.4 \pm 0.3$ & $8.6 \pm 0.6$ \\
\hline C. nimbasilvanus & $36.8 \pm 0.7$ & $4.3 \pm 0.6$ & $7.8 \pm 0.5$ & $13.6 \pm 0.7$ & $11.6 \pm 0.7$ & $17.4 \pm 0.01$ & $8.3 \pm 0.7$ & $8.1 \pm 1.4$ & $24.9 \pm 0.9$ & $15.4 \pm 0.7$ & $10.1 \pm 0.5$ \\
\hline
\end{tabular}

on the opposite positive side, the two largest species, C. olivieri and C. nimbasilvanus. We obtained a total of $83.6 \%$ of correctly classified specimens with the highest scores (100\%) for three species $C$. olivieri, $C$. nimbae and $C$. nimbasilvanus. The worst scores were obtained for $C$. grandiceps $(52.6 \%)$ and $C$. eburnea (40\%) for which some specimens were incorrectly classified and regrouped by the analysis inside $C$. theresae, C. buettikoferi and $C$. obscurior variability ranges (Appendix 7).

The same observations about size classes were made for craniodental measurements for only those species present at Mount Nimba (Table 6) with C. obscurior being the smallest shrew and C. nimbasilvanus the largest. Crocidura nimbae, which was not captured during this study, is a relatively large shrew with skull proportions close to other medium- to large-sized species such as C. grandiceps, C. buettikoferi and C. theresae (Appendices 4, 5).

\section{Identification key}

The identification key, based mostly on visual and microscope morphology plus external measurements, was tested by one of us (FJ) based on Guinean and Liberian specimens from Mount Nimba and type specimens housed in MNHN. In order to facilitate identifications in the field we used for each step one external qualitative or quantitative character. Qualitative characters were indicated in Heim de Balsac's (1956, 1958) descriptions and through our observations. Quantitative characters are provided in Tables 5, 6. For C. eburnea and C. obscurior we were unable to find any external characters that allowed us to differentiate them, which resulted in our decision to pool these two species in the dichotomous key presented below. 


\section{IDENTIFICATION KEY FOR SHREW SPECIES PRESENT AT MOUNT NIMBA}

(abbreviations see Material and methods)

1. Tail skin naked and ringed; four pairs of maxillary unicuspids

- Tail skin hairy or non ringed, three pairs of maxillary unicuspids

S. megalura (Jentink, 1888)

2. Ratio TL/HB $>1$

C. muricauda (Miller, 1900)

- Ratio TL/HB $<1$

3. $\mathrm{HB}<70 \mathrm{~mm}$

- $\mathrm{HB}>110 \mathrm{~mm}$

- HB between 70 and $110 \mathrm{~mm}$

4. Ratio $\mathrm{TL} / \mathrm{HB}<0.8$

— Ratio TL/HB between 0.8 and 1

C. obscurior/eburnea Heim de Balsac, 1958

5. $\mathrm{HB}>130 \mathrm{~mm}$ C. douceti Heim de Balsac, 1958

- HB between 110-130 mm, brownish, black hairs

6. $\mathrm{HF}>17 \mathrm{~mm}$ C. olivieri (Lesson, 1827)

- $\mathrm{HF}<17 \mathrm{~mm}$ C. grandiceps Hutterer, 1983

7. Proportion of tail covered by vibrissae $>50 \%$; fur color brown

— Proportion of tail covered by vibrissae $<50 \%$; fur color black C. buettikoferi Jentink, 1888

8. End of tail with visible skin, spare hairs

- Hair covering at end of tail C. theresae Heim de Balsac, 1968

9. $\mathrm{HF}>14 \mathrm{~mm}$ C. nimbae Heim de Balsac, 1956

- $\mathrm{HF}<14 \mathrm{~mm}$ C. jouvenetae Heim de Balsac, 1958

\section{DISCUSSION}

\section{SHREW DIVERSITY, HABITAT ASSOCIATIONS AND CONSERVATION ISSUES}

During our extensive surveys we were able to capture all shrew species previously recorded from Mount Nimba and surrounding areas (Heim de Balsac 1958, 1974; Coe 1975; Verschuren \& Meester 1977; Churchfield et al. 2004; Nicolas et al. 2009), except for $C$. nimbae. On the Liberian side of Mount Nimba, Coe (1975) collected only two species: C. occidentalis (Pucheran,1855) - now named C. olivieri) and C. poensis (Fraser,1843) (now named C. buettikoferi). Despite extensive tracts of rainforest remaining at Mount Nimba (Monadjem et al. 2016), and despite our relatively high sampling effort, we were still unable to capture $C$. nimbae, suggesting either that it is very rare, or that it selects a very specific habitat that we did not sampled as already suggested by Heim de Balsac (1958) in his original description. Crocidura nimbae was recently trapped by Nicolas et al. (2009) in Ziama forest, where it represented only $0.4 \%$ of the captures. More recently, it has again been recorded from Ziama, by a single specimen (Mamba et al. 2021). These two studies confirm the rarity of $C$. nimbae.

We confirm here for the first time that $C$. eburnea occurs on the Liberian side of Mount Nimba and that it is sympatric with $C$. obscurior in that region. Its absence on the Guinean side of Mount Nimba (Jacquet et al. 2014) and more generally in western parts of Eastern Guinea, despite extensive sampling, needs to be verified by further studies, but may be related to the relatively drier conditions there.
Of the shrews that occur at Mount Nimba, three species are currently classified as "Near Threatened": Crocidura buettikoferi, C. grandiceps (13.7 and $7.1 \%$ of all captures, respectively) and $C$. nimbae (no captures during our study). We captured a single specimen of the rare $C$. douceti, whose conservation status is currently "Least Concern" (IUCN, 2019). This species has been rarely captured since its original description in 1984. In Ziama forest Nicolas et al. (2009) reported a low relative abundance at 5.9\%, and Mamba et al. (2021) recorded a single individual from Wologizi forest in Liberia. Based on these observations, we suggest that the conservation status of this species be re-appraised. To date, there is no IUCN assessment for the two most recently recognised species, C. eburnea and $C$. nimbasilvanus. We captured two specimens of $C$. nimbasilvanus and 12 specimens of C. eburnea.

The 12 species of shrews currently known at Mount Nimba may be an underestimate because the high genetic divergence between the two lineages of C. muricauda (Jacquet et al. 2012) may represent cryptic species and requires further investigation.

When compared with the shrew diversity of the Upper Guinea rainforest zone, which harbours 16 species (Burgin \& He 2018) we did not record the following species in our study: C. nimbae, C. crossei, C. lamottei, C. nigeriae and C. wimmeri. Crocidura nimbae was recovered in S Sierra Leone, N Liberia and SW Côte d'Ivoire in Taï National Park (Churchfield et al. 2004, Hutterer 2005) and Dodo-Cavally forest reserve (Decher et al. 2005) as well as in Ziama forest (Nicolas et al. 2009, Mamba et al. 2021) and in Mount Nimba in Zougepo (Heim de Balsac 1958). It is not clear whether $C$. crossei is present in West Africa because formerly it was treated as conspecific 
with $C$. jouvenetae, which is now considered as a distinct valid species. Crocidura lamottei was described from Lamto (Côte d'Ivoire) and does not occur in forested environments. Crocidura wimmeri is classified as Critically Endangered and was collected only in Adiopodoume and Banco National Park near Abidjan (Côte d'Ivoire) in a secondary forest (Kadjo et al. 2013, Vogel et al. 2014). Crocidura nigeriae, described from Nigeria, is supposed to be also present in SE Côte d'Ivoire and NE Ghana (Burgin \& He 2019) but a recent phylogenetic study concluded that West African specimens attributed to this species should be renamed (Nicolas et al. 2009, 2020). According to Heim de Balsac (1971) C. denti could be present on Mount Loma (Sierra Leone) but these specimens most probably represent misidentifications (Dambry et al. 2016).

The species associations we report here are like those previously published, even though their abundances vary. The three forest-dwelling species C. obscurior (excluding C. eburnea), $C$. jouvenetae and $C$. buettikoferi were also trapped in the highelevation savannah (at $1600 \mathrm{~m}$ asl) during both wet and dry seasons. Furthermore, our study revealed that most species from Mount Nimba live in syntopy, sharing the same habitat. The lowland primary and secondary forests at $600 \mathrm{~m}$ asl harboured 11 shrew species representing two genera (Table 7). This species richness is similar to that reported in other West African (Churchfield et al. 2004; Nicolas et al. 2009; Mamba et al. 2021) and Central African (Brosset 1988; Nicolas et al. 2005) rainforests. Nevertheless, some more species rich communities have been recorded in the rainforests of the Central African Republic. For example, Ray \& Hutterer (1996) found four genera and 16 species in Kongana, Barrière \& Nicolas (2000) reported five genera and 18 species in Ngotto forest, and Barrière et al. (2005) reported two genera and 14 species in the north of the country. Similarly, Van de Perre et al. (2019) reported 22 species of shrews in the Kisangani area of the Democratic Republic of Congo, of which four were without a scientific name.

We could compare these species abundance data to those of other surveys led in Tai forest (Churchfield et al. 2004), in Haute Dodo and Cavally forests (Decher et al. 2005) and in Ziama forest (Nicolas et al. 2009; Mamba et al. 2021) (Fig. 6). In Taï and Ziama forests, C. obscurior $+C$. eburnea, C. jouvenetae and $C$. buettikoferi were abundant, while $C$. douceti, C. nimbae and C. nimbasilvanus were rare. All were typical forest-dwelling species and were trapped in gallery or secondary forests on Mount Nimba. The relative abundance of the species C. olivieri, C. grandiceps and S. megalura are higher in Mount Nimba than in other studies (Fig. 7). Crocidura obscurior + C. eburnea, C. muricauda dominate in Taï and in Ziama. In Dodo/Cavally it is C. obscurior + eburnea, C. jouvenetae and C. theresae that dominate the community. Crocidura theresae has been recorded from Guinean savannahs, mixed forest and savannah areas and rice fields (Verschuren \& Meester 1977; Hutterer 2005; Wilson \& Mittermeier 2018), while C. olivieri and $S$. megalura were encountered in a wide variety of forest and savannah habitats (Hutterer 2005). Crocidura grandiceps is associated with primary rain forests (Hutterer 1983; Grubb et al. 1998), but has also been recorded from small scattered forest fragments surrounded by savannahs in Ghana (Hutterer 2005), and in our study a single individual was trapped in a house. Several authors have reported a synanthropic behavior of C. olivieri (Heim de Balsac 1968, 1974; Heim de Balsac \& Barloy 1966; Verschuren \& Meester 1977, Nicolas et al. 2020), but we did not trap this species in houses. Crocidura eburnea is found in lowland forests up to $600 \mathrm{~m}$. We did not capture it in montane forest or in high-elevation savannah, which is in contrast to C. obscurior that was found at all elevations and in all vegetation types. The peculiar composition of the shrew community at Mount Nimba compared with other West African forests can be explained by the geographic location of this mountain at the ecotone zone between rainforest and Guinean woodland. Mount Nimba thus harbours a mixed shrew community composed of both savannah and forest-dwelling taxa.

Crocidura muricauda is less abundant on Mount Nimba (5.3\% of all captures) than in Ziama and Tai National Parks forests (respectively $19.35 \& 21.5 \%$ ) (Fig. 7). Heim de Balsac (1958) had already noticed the scarcity of this forest-dwelling species on Mount Nimba (four specimens out of more than 100 shrew specimens). Nicolas et al (2009) observed that in Ziama C. muricauda is a typical forest species: it was much more abundant at sites with high understorey density, high canopy height and cover, and high density of stems and trees, than in logged or agricultural landscapes. Both lowland and montane forests in the Nimba Mountains are of variable states of integrity, ranging from relatively intact to highly degraded by anthropogenic activities (seasonal fires across the entire range, mining in two localised areas, and logging and clearance for agriculture in the lowlands). This may explain the relative rarity of $C$. mauricauda on Mount Nimba. None of the forest-dwelling shrew species on Mount Nimba appeared to be restricted to primary habitat. These results are congruent with those of the long-term study of Nicolas et al. (2009) in Ziama Man Biosphere Reserve forest who demonstrated that shrew communities were not significantly affected by agricultural activities and that their diversity was similar in primary and secondary forests.

At Mount Nimba, the shrew community in montane forest (1000-1350 $\mathrm{m}$ asl) was not different from that in lowland forest except in terms of diversity with seven species instead of 11 ; demonstrating that the shrew community in montane forest may be a subset of that in lowland forest (Table 7). However, for logistics reasons our trapping efforts concentrated mostly on lowland forest (6750 Trap nights) compared to montane forest (2573 trap nights). The edaphic savannah (from 1200 to $1600 \mathrm{~m}$ asl), which is peculiar to the Guinean side of Mount Nimba, harboured five species, C. obscurior, C. jouvenetae, C. theresae, C. buettikoferi and S. megalurus. Only two species, $C$. obscurior and $C$. theresae, were recorded from this habitat by Heim de Balsac (1958), Verschuren \& Meester (1977) and Lamotte \& Roy (2003). Crocidura theresae was found in grassland savannahs, bush between 600 and $1600 \mathrm{~m}$ by Verchuren \& Meester (1977). The altitude savannah biotope does not seem to promote isolation for shrews, as no endemic taxon was identified, suggesting that this vegetation 


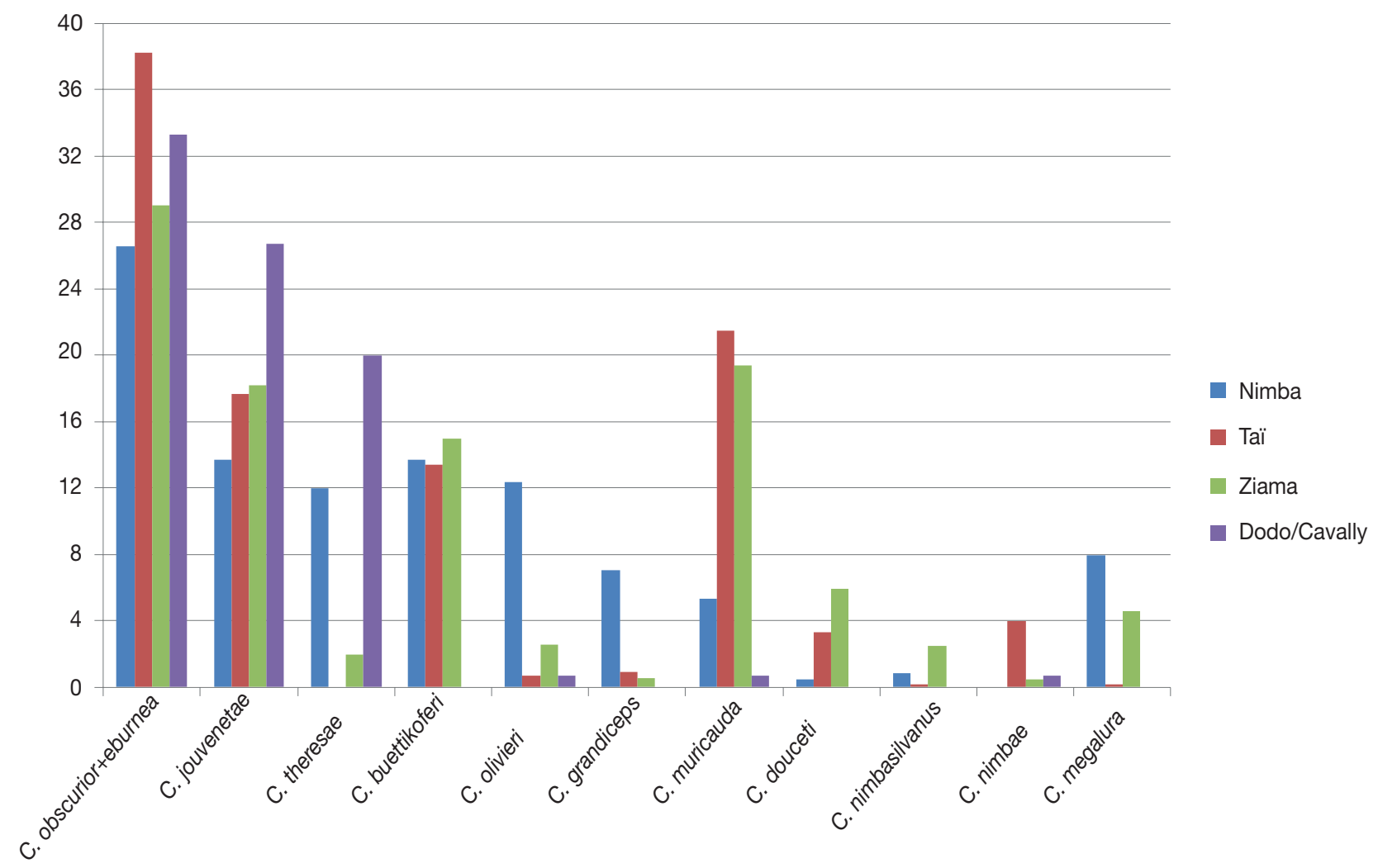

FIG. 7. - Comparison of the relative abundance (\% on y axis) of shrew species between four different surveys. Nimba this work ( $\mathrm{N}=226)$, Taï: Churchfield et al. (2004) $(\mathrm{N}=553)$, Ziama: Nicolas et al. (2009) $(\mathrm{N}=2571)$, Dodo-Haut Cavally: Decher et al. (2005) $(\mathrm{N}=15)$. For authorships of the species, see Table 5.

is relatively recent in origin. Our results suggest that shrews demonstrate habitat plasticity at Mount Nimba, as suggested by Verschuren \& Meester (1977). Some species like C. eburnea and $C$. douceti or $C$. nimbasilvanus were found only in lowland forests. They all corresponded to species trapped in low abundance despite relatively intense trapping on the Guinean side of the Mount in this environment. Crocidura douceti is known in relict and gallery forest as well as anthropogenic environments in Taï National Park (Churchfield et al. 2004) but was considered as a forest shrew of low density by Heim de Balsac (1958). The holotype of C. eburnea comes from Mt Tonkoui situated at $1200 \mathrm{~m}$ asl, which could indicate that the species is also living in montane forest of Nimba range region. Crocidura nimbasilvanus is more common in closed environments according to Nicolas et al. (2009) but was captured in low abundance in Ziama forests. According to Burgin \& He (2018), C. nimbae is found in submontane and lowland forest but was known by a few specimens in Zouguepo Nimba lowland forest (Heim de Balsac 1958).

\section{Cytogenetic CHARACTERIZATION OF MOUNT Nimba SHREWS}

Cytogenetic analyses in mammals showed that there is extensive karyotypic diversity among extant species and that many closely related species or even populations possess different karyotypes indicating that chromosomal differentiation often occurs during, or shortly after cladogenesis (Dobigny et al.
2017). Thus, descriptions of mammalian karyotypes serve an important role for characterizing chromosomal rearrangements, which provide information on genetic barriers to gene flow and ultimately on the processes involved in speciation. In this paper we provide cytogenetic data for five of the 11 captured species. For each species several individuals were studied in order to test for intraspecific variability but a remarkable result of this study is that karyotypes of all species are stable. In the following paragraphs we compare our data with previously published data from the same or closely related species.

The standard karyotype of $C$. buettikoferi is characterized by $2 \mathrm{n}=52$ and $\mathrm{NFa}=66$. Our results are in good agreement with the report of Meylan (1971) and Meylan \& Vogel (1982) from Côte d'Ivoire (as C. poensis pamela Dollman, 1915). The authors identified 17 pairs of acrocentric decreasing in size, five pairs of subtelocentric and three pairs of small meta/submetacentric chromosomes. The X and Y chromosomes are a large-sized metacentric and a small acrocentric, respectively. It is important to note that $C$. buettikoferi from Mount Nimba has very small short arms at the $9^{\text {th }}$ pair of autosomes, the same as $C$. olivieri $\left(7^{\text {th }}\right)$ and $C$. theresae $\left(12^{\text {th }}\right)$. With a significant chromosome contraction, those arms are barely noticeable. In addition, they are C-positive and vary in size, so we consider this pair of autosomes as acrocentric.

The karyotype of $C$. grandiceps is $2 \mathrm{n}=46$ and $\mathrm{NFa}=64$. This is in agreement with data previously published by Meylan $\&$ Vogel (1982) in Côte d'Ivoire, as C. cf. nimbae. 
TABLE 7. - Elevational distribution of newly collected shrews of Mount Nimba.

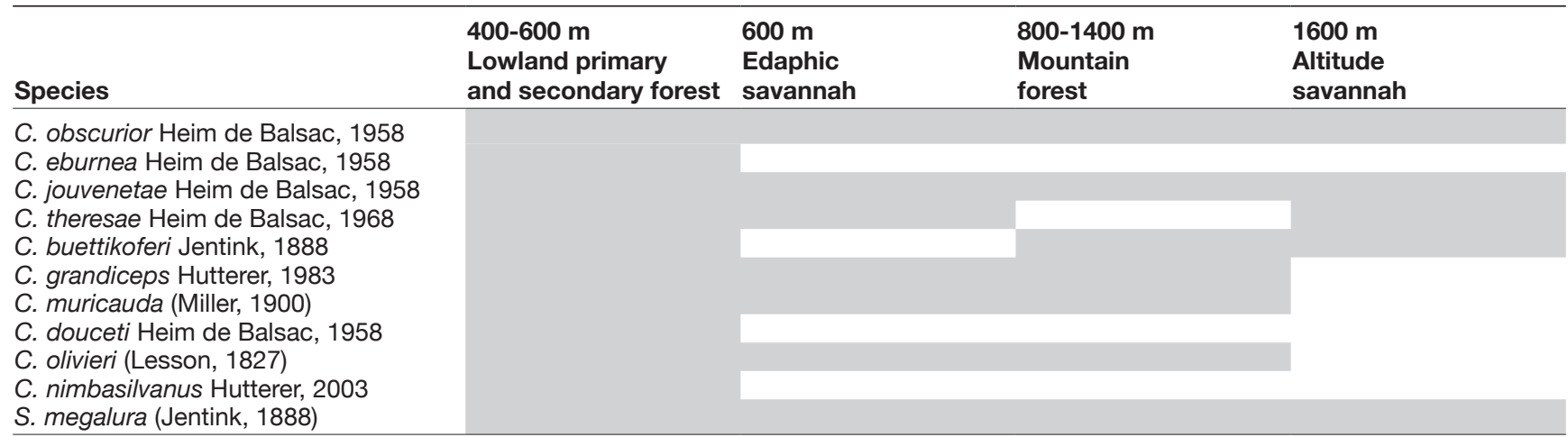

Our specimens of $C$. jouvenetae are characterized by $2 \mathrm{n}=44$ and $\mathrm{NFa}=68$. The first karyotype of $C$. jouvenetae was described from Côte d'Ivoire by Meylan (1971) with $2 \mathrm{n}=44$ and $\mathrm{NFa}=62$. Variation in the short arms of several pairs of chromosomes can result from difficulties in categorizing chromosomes and homologous pairs, which can be considered as acrocentric or subtelocentric (see Fig. 2 in Meylan, 1971). The chromosome formula $2 \mathrm{n}=44$ and $\mathrm{NFa}=62$ was described for C. crossei (jouvenetae) ebriensis from Côte d'Ivoire (Meylan \& Vogel 1982), but the taxonomic status of these specimens still needs to be assessed and they could be a synonym of $C$. jouvenetae (Hutterer 2005). In the same work, Meylan \& Vogel (1982) described the karyotype of $C$. cf. planiceps from Côte d'Ivoire, which also displayed $2 \mathrm{n}=44$, but differed by $\mathrm{NFa}=68$. The five C. jouvenetae investigated in our study display the same standard formula as $C$. cf. planiceps. According to Wilson \& Mittermeier (2018) the species C. planiceps Heller, 1910 is known from Nigeria and Uganda. Thus the taxonomic status of the $C$. cf. planiceps specimens from Côte d'Ivoire needs to be re-evaluated. However, an integrative study combining morphological, molecular and cytogenetic data is now required to review the phylogeography and taxonomy of the species $C$. jouvenetae.

Cytogenetic (Meylan 1967, 1971; de Hondt 1974; Meylan \& Vogel 1982; Baskevitch et al. 1995; Lavrenchenko et al. 1997) and molecular studies (Quérouil et al. 2005; Dubey et al. 2007, 2008; Jacquet et al. 2015) have led to the unification of a high number of large-sized shrews under the name $C$. olivieri (Hutterer 2005; Burgin \&He 2018). A summary of the various available karyotypic data for $C$. olivieri was presented by Schlitter et al. (1999). The first karyotype of C. olivieri was described by Meylan (1967) under the name C. occidentalis kivu Osgood, 1910 from Democratic Republic of Congo with $2 n=50$ and $\mathrm{NFa}=62$. Later surveys from various parts of Africa revealed the same karyotype for all forms that are currently considered conspecific to C. olivieri (Meylan 1971 from Côte d'Ivoire; de Hondt, 1974 from Egypt; Meylan \& Vogel 1982 from Mali, Cameroon, Nigeria and Burkina Faso; Baskevitch et al. 1995 from Ethiopia). The formula we describe here from Mount Nimba $(2 \mathrm{n}=50, \mathrm{NFa}=60)$ is in agreement with these previous surveys. However, some differences exist in categorizing acrocentric/subtelocentric largest pair of autosomes. In the first studies, this pair is considered as acrocentric (Meylan 1967, 1971). In later papers, it is attributed to the subtelocentric (De Hondt 1974; Meylan \& Vogel 1982; Maddalena et al. 1987; Lavrenchenko et al. 1997; Schlitter et al. 1999). In our study we adhere to the terms of Meylan (1967, 1971). We consider this pair of autosomes as acrocentric because its very small short arms are C-positive and can vary in size, while the short arms of the other two pairs of subtelocentrics are C-negative and dimensionally stable (Aniskin, unpubl. data).

The diploid number of $C$. theresae from Mount Nimba is the same as $C$. olivieri $(2 \mathrm{n}=50)$, but the karyotype differs by the fundamental number of autosomes $(\mathrm{NFa})$. In our study the karyotype of $C$. theresae comprises 11 pairs of bi-armed autosomes and 13 acrocentric pairs, with $\mathrm{NFa}=70$. Our results show some differences with the karyotype of $C$. theresae from Côte d'Ivoire by Meylan (1971), who identified 15 pairs biarmed autosomes and nine acrocentric pairs, with $\mathrm{NFa}=78$. Additional analyses combining morphological, molecular and cytogenetic data is now required to review the phylogeography and taxonomy of this species.

\section{MORPHOMETRIC CHARACTERISTICS OF SHREWS FROM MOUnT NimBA}

Some species could not readly be discriminated with certainty based on morphometric analyses. This is particularly the case for $C$. eburnea and $C$. obscurior for which external and craniodental measurements overlapped significantly (Tables 5, 6), demonstrating their status as sibling species. The two holotypes have distinct sizes (Appendix 3), with C. eburnea slightly smaller, but this difference disappears when additional specimens are included in the analysis. In the original description, Heim de Balsac (1958) highlighted some dental differences between these taxa like a more developed P3 and paracone of P4. These characters were not validated as diagnostic by Jacquet et al (2014), who instead demonstrated that both species are small sized ones (body length 50-65 mm) with a uniform dark pigmentation of the skin and the fur (Jacquet et al. 2014). 
The morphometric analyses based on weight, external and craniodental measurements show that sympatric shrew species from Mount Nimba can be classified along a size gradient from the tiny $C$. obscurior-C. eburnea to the giant $C$. nimbasilvanus. This is congruent with the size range theory of Brosset (1988), who demonstrated that within a shrew community composed of 11 species from Makokou forest (Gabon), each species was replaced by another along a size gradient. All species were syntopic and showed the same activity periods. This suggests that species-rich shrew communities in African rain forests partition resources in this way, decreasing interspecific competition and allowing coexistence of multiple species (Hutterer et al. 1987; Brosset 1988; Churchfield et al. 1999; Goodman et al. 2001).

The morphometric analyses also reveal an important intraspecific uniformity for most species. External measures are thus often used to define diagnostic characters and to build identification keys (Hutterer \& Happold 1983) (Appendices 4; 5). A notable exception is found between the smallest species C. eburnea and C. obscurior which are impossible to separate by external size characters (Jacquet et al. 2014).

\section{MORPHOLOGICAL IDENTIFICATION KEY}

We developed an identification key based as much as possible, on both body measurements (head $\&$ body, tail and hindfoot lengths, tail / head + body length ratio) and external characters (fur and skin color, tail hairiness, quantity and length of tail vibrissae). The same characters were used by Hutterer $\&$ Happold (1983) to build a key for Nigerian shrews. Our key needs to be tested in the future on other west African sites and be amended by the missing taxa once they have been well described using an integrative taxonomic approach sensu Taylor et al. (2019).

\section{CONCLUSION}

Our surveys on the Guinean and Liberian slopes of Mount Nimba has allowed us to better understand the biodiversity and ecological requirements of shrews at this unique mountain. We collected 11 species of shrews in total, which confirmed the high diversity of shrews on Mount Nimba, especially in lowland forests (11 species) compared to the edaphic savannah from 1200 to $1600 \mathrm{~m}$ (five species). Only three species known in the western parts of the Upper Guinea rainforest zone were not captured in our study: $C$. nimbae, $C$. wimmeri and $C$. lamottei. The shrew community at Mount Nimba combines a mixture of both savannah (Crocidura theresae, C. olivieri, S. megalurus) and forest-dwelling species ( $C$. buettikoferi, C. obscurior, C. eburnea, C. jouvenetae and C. nimbasilvanus). This highlights the importance of Mount Nimba for the conservation of shrews, as has been demonstrated for bats (Monadjem et al. 2016). We also described for the first time karyological data of shrews from Mount Nimba. Our results were congruent with previous data, except for $C$. theresae, for which differences with a karyotype described from Côte d'Ivoire were highlighted, maybe owing to cryptic vari- ability. Morphometric analyses based on external body and craniodental measurements revealed that shrew species from Mount Nimba can be classified along an increasing size gradient, congruently with the size range theory of Brosset (1988). Based on body measurements and external characters, we developed an identification key of shrews from Mount Nimba, which can be easily used in the field and on live animals.

\section{Acknowledgements}

We would like to thank the non-governmental organization "Nature Conservation", the organizers of the BIORAP Nimba of 2008, Dr F Lauginie and G Rondeau, the BHP BILLITON and the Société des Mines de Fer de Guinée (SMG). We thank Jamison Suter (Environmental and Social External Relations Manger of the SFMG who kindly read, commented and approved this manuscript. We are also grateful to Dr L. Koivogui and C. Camara for their active participation in the field study. The research and exportation authorisations were provided by the Guinean Ministry "Eaux et Forêts" and we are grateful to Dr C. Sagno and O. Diallo. We dedicate this work to the late Fodé Kourouma who participated to the 2008, 2010 and 2013 fieldworks and was a great field assistant. Fodé Kourouma also prepared the skulls. M. Mfonkumun prepared skulls under supervision of A. Delapré in SPOT (Paris, MNHN). Peter Farnloe and Moses Darpey provided fantastic assistance in the field; their effort and company was greatly appreciated. Tanya Romanenko was always quick to provide support wherever it was needed during earlier trips to Liberian Nimba. Martyn Gest is thanked for help in the field during March 2013. Wing-Yunn Crawley and John Howell, ArcelorMittal, have provided critical support for continued biodiversity studies on the ArcelorMittal concession. AM and CD were employed by ArcelorMittal and SMFG and had signed non-disclosure agreements with these mining companies. Molecular analyses were performed at the Service de Systématique moléculaire (UMS 2700 Acquisition et Analyse de Données pour l'Histoire naturelle (2AD), MNHN, Paris). Guy Rabache must be thanked for his help on figures design. The authors wish to thank Dr Jan Decher and an anonymous referee who helped to improve our manuscript.

\section{REFERENCES}

Barriere P. \& Nicolas V. 2000. - Rapport d'expertise sur la Biodiversité animale en forêt de Ngotto (République Centrafricaine): Ecologie et structuration des peuplements de micromammifères: Musaraignes et Rongeurs. Rapport ECOFAC-CEE, AGRECOCTFT: 46 p.

Barrière P., Hutterer H., Nicolas V., Quérouil S. \& Colyn M. 2005. - Investigating the role of historically isolated gallery forests outside the Congolese forest block as a refuge for African forest shrews. Belgian Journal of Zoology 135: 27-35.

Baskevitch M. I., Orlov V. N., Bekele A. \& Membrate A. 1995. - New data on the karyotypes of Ethiopian small mammals (Insectivora, Rodentia), in SoKOLOV V. E. ed, Theriological Investigations in Ethiopia Nauka, Moscow, Russia: 58-72. 
Brosset A. 1988. — Le peuplement de mammiferres insectivores des forêts du nord-est du Gabon. Revue d'Ecologie (La Terre et La Vie) 43: 23-46.

Burgin C. J. \& He K. 2018. — Family Soricidae (shrews), in Wilson D. E. \& Mittermeier R. A. (eds), Handbook of the mammals of the world. Vol 8. Insectivores, sloths and colugos. Lynx Edicions, Barcelona: 332-551.

Churchfield S., Nesterenko V. A., ShVarts E. A. 1999. — Food niche overlap and ecological separation amongst six species of coexisting forest shrews (Insectivora: Soricidae) in the Russian Far East. Journal of Zoology 248: 349-359.

Churchield S., Barrière P., Hutterer R. \& Colyn M. 2004. First results on the feeding ecology of sympatric shrews (Insectivora: Soricidae) in the Tai National Park, Ivory Coast. Acta Theriologica 49: 1-15.

Coe M. 1975. - Mammalian ecological studies on Mount Nimba, Liberia. Mammalia 39: 523-588.

Dambry A., Bryja J., Gambalemoke S., Verheyen E., Missoup A. D ., COlYN M. \& NicOlas V. 2016. - Phylogeography and evolutionary history of the Crocidura hildegardae complex (Mammalia, Soricomorpha). $4^{\text {th }}$ International Colloquium Biology of the Soricidae, Poznan, Pologne: 16-17.

Decher J., Hoffmann A., Schaer J., Norris R. W., Kadjo B., Astrin J., Monadjem A. \& Hutterer R. 2015. — Bat diversity in the Simandou Mountain Range of Guinea, with the description of a new white-winged vespertilionid. Acta Chiropterologica 17: 255-282. https://doi.org/10.3161/15081109ACC2015.17.2.003

Decher J., Kadjo B., Abedi-Lartey M., Tounkara E. O. \& KANTE S. 2005. - A rapid survey of small mammals (shrews, rodents, and bats) from the Haute Dodo and Cavally Forests, Côte d'Ivoire, in Alonso L. E., Lauginie F. \& Rondeau G. (eds), A rapid biological assessment of two classified forests in south-western Côte d'Ivoire. RAP Bulletin of Biological Assessment 34: 101-109.

Decher J., Schlitter D. A. \& Hutterer R. 1997. — Noteworthy records of small mammals from Ghana with special emphasis on the Accra Plains. Annals of the Carnegie Museum 66: 207-225.

De Hondt H. A. 1974. - Karyological studies on two insectivores of Egypt. Proceedings of the Egyptian Academy of Sciences 25: 171-174.

DenYs C. \& ANiskine V. 2012. - On a new species of Dendromus (Rodentia, Nesomyidae) from Mount Nimba, Guinea. Mammalia 76: 295-308. https://doi.org/10.1515/mammalia-2011-0012

DIPPENAAR N. J. 1977.. - Variation in Crocidura mariquensis (A. Smith, 1844) in southern Africa, Part I (Mammalia, Soricidae). Annals of the Transvaal Museum 32: 1-34.

Dobigny G., BritTon-Davidian J. \& Robinson T. J. 2017. Chromosomal polymorphism in mammals: an evolutionary perspective. Biological Review of the Cambridge Philosophical Society 92: 1-21. https://doi.org/10.1111/brv.12213

Dubey S., Salamin N., Ohdachi S. D., Barrière P. \& Vogel P. 2007. - Molecular phylogenetics of Soricidae (Mammalia, Eulipotyphla) reveals timing of transcontinental colonizations. Molecular Phylogenetics and Evolution 44: 126-137. https://doi. org/10.1016/j.ympev.2006.12.002

Dubey S., Salamin N., Ruedi M., Barrière P., Colyn M., Vogei P. 2008. - Biogeographic origin and radiation of the Old World crocidurine shrews (Mammalia: Soricidae) inferred from mitochondrial and nuclear genes. Molecular Phylogenetics and Evolution 48: 953-963. https://doi.org/10.1016/j.ympev.2008.07.002

FAHR J. \& KALKO E. K. V. 2011. - Biome transitions as centres of diversity: habitat heterogeneity and diversity patterns of West African bat assemblages across spatial scales. Ecography 34: 177195. https://doi.org/10.1111/j.1600-0587.2010.05510.x

GambalemoKe M., Mukinzi I., Amundala D., Gembu T., Kaswera K., Katuala G.-B., Dudu A., Barrière P., Colyn M., Hutterer R., Kennis J., Leirs H., Vanlinden B. \& Verheyen E. 2008. - Microgeographical distribution of shrews (Mammalia,
Soricidae) in the Congo River basin (Kisangani, D.R. Congo) Mammalia 72: 213-222.

Goodman S. M., Hutterer R. \& Ngnegueu P. R. 2001. - A report on the community of shrews (Mammalia: Soricidae) occurring in the Minkebe Forest, north-eastern Gabon. Mammalian Biology 66: 22-34. https://www.biodiversitylibrary.org/ part/192458

Granier N. \& MARTINEZ L. 2011. - Conservation Issues in the Nimba Mountains, in Matsuzawa T., Tatyana Humle T. \& SugiYama Y. (eds.). The Chimpanzees of Bossou and Nimba. Springer, Tokyo, Japan: 381-392.

Grubb P., Jones T. S., Davies A. G., Edberg E., Starin E. D. \& HiLl J. E. 1998. - Mammals of Ghana, Sierra Leone and the Gambia. The Trendline Press, Zennor, St. Ives, Cornwall, United Kingdom, 265 p.

Happold M. \& Happold D. C.D. 2013. - Mammals of Africa, IV, Hedgehogs, Shrews and Bats, Bloomsbury Publishing, London, 803 p.

Heim DE BALSAC H. 1956. - Diagnoses de Crocidura inédites d'Afrique Occidentale. Mammalia 20: 131-139.

HEIM DE BALSAC H. 1958. — La réserve naturelle intégrale du mont Nimba. XIV. Mammifères insectivores. Mémoires de l'Institut Français d'Afrique Noire 53: 339-357.

HEIM DE BALSAC H. 1968. — Recherches sur la faune des Soricidae de l'Ouest Africain (du Ghana au Sénégal). Mammalia 32: 379-418.

Heim DE BALsaC H. 1971. — Le massif des Monts Loma (Sierra Leone). Fasc.1. XX. Mammiferes muridae et Soricidae. Mémoires de l'Institut Français d'Afrique Noire 86: 409-417.

Heim DE BALSAC H. 1974. - Les insectivores de Lamto (Côte d'Ivoire). Mammalia 38: 637-646.

Heim de Balsac H. \& Barloy J. J. 1966. - Révision des Crocidures du groupe flavescens. — occidentalis. — manni. Mammalia 30: 601-633.

HUTTERER R. 1983. - Crocidura grandiceps, eine neue Spitzmaus aus Westafrika. Revue Suisse de Zoologie 90: 699-707.

Hutterer R. 2005. - Order Soricomorpha, in WiLSON D. E.\& ReEder D. M. (eds), Mammal Species of the World: A Taxonomic and Geographic Reference, 3rd ed. Johns Hopkins University Press, Baltimore: 220-310.

HutTERER R. 2008. - Crocidura nimbae, C. buettikoferi, C. grandiceps. In: IUCN 2011, IUCN Red List of Threatened Species. Online at: www.iucnredlist.org (accessed 10 March 2013).

HutTERER R. \& Happold D. C.D.1983. - The shrews of Nigeria (Mammalia: Soricidae). Bonner Zoologische Monographien 18: 1-79.

HutTERER R. \& KocK D. 2002. - Recent and ancient records of shrews from Syria, with notes on Crocidura katinka Bate, 1937 (Mammalia: Soricidae). Bonner Zoologische Beiträge 50: 249-258.

Hutterer R., Van der Straeten E. \& Verheyen WN. 1987. - A checklist of the shrews of Rwanda and biogeographical considerations of African Soricidae. Bonner Zoologische Beiträge 38: 155-172.

Hutterer R., Decher J., Monadjem A. \& Astrin J. 2019. A new genus and species of vesper bat from West Africa, with notes on Hypsugo, Neoromicia, and Pipistrellus (Chiroptera: Vespertilionidae). Acta Chiropterologica 21: 1-22. https://doi.org/1 0.3161/15081109ACC2019.21.1.001

Igbokwe J., Nicolas V., Oyeyiola A., Obadare A., Adesina A. S., Awodiran M. O., Van Houtte N., Fichet-Calvet E., Verheyen E. \& Olayemi A. 2019. - Molecular taxonomy of Crocidura species (Eulipotyphla: Soricidae) in a key biogeographical region for African shrews, Nigeria. Comptes Rendus Biologies 342: 108-117. https://doi.org/10.1016/j.crvi.2019.03.004.

Jacquet F., Nicolas V., Bonillo C., Cruaud C. \& Denys C. 2012. - Barcoding, molecular taxonomy and exploration of the diversity of shrews (Soricomorpha: Soricidae) on Mount Nimba (Guinea). Zoological Journal of the Linnean Society 166: 672-687. https://doi.org/10.1111/j.1096-3642.2012.00856.x

Jacquet F., Hutterer R., Nicolas V., Decher J., Colyn M., Couloux A. \& Denys C. 2013. - New status for two African 
giant forest shrews Crocidura goliath goliath and C. goliath nimbasilvanus (Mammalia, Soricomorpha) based on molecular and geometic morphometric analyses. African Zoology 48: 13-29. https://doi.org/10.3377/004.048.0108

Jacquet F., Nicolas V., Colyn M., Kadjo B., Hutterer R., Decher J., Akpatou B., Cruaud C. \& Denys C. 2014. Forest refugia and riverine barriers promote diversification in the West African pygmy shrew (Crocidura obscurior complex, Soricomorpha). Zoologica Scripta 43 (2): 131-148. https://doi. org/10.1111/zsc. 12039

Jacquet F., Denys C., Verheyen E., Bryja J., Hutterer R., Kerbis Peterhans J. C., Stanley W. T., Goodman S. M., Couloux A., ColYN M. \& Nicolas V. 2015. — Phylogeography and evolutionary history of the Crocidura olivieri complex (Mammalia, Soricomorpha): from a forest-based origin to a broad ecologi$\mathrm{cal}$, expansion across Africa. BMC Evolutionary Biology 15: 71 (23 April 2015). https://doi.org/10.1186/s12862-015-0344-y.

Kadjo B., Kouadio R. Y., Vogel V., Dubey S. \& Vogel P 2013. - Assessment of terrestrial small mammals and a record of the critically endangered shrew Crocidura wimmeri in Banco National Park (Côte d'Ivoire). Mammalia 77: 439-446. https:// doi.org/10.1515/mammalia-2012-0083.

Kang H. J., Kadjo B., Dubey S., Jacguet F. \& Yanagihara R. 2011. - Molecular evolution of Azagny virus, a newfound hantavirus harbored by the West African pygmy shrew (Crocidura obscurior) in Côte d'Ivoire.Virology Journal 8: 373. http://www. virologyj.com/content/8/1/373.

KASANGAKI A., KitYo R. \& KeRBIS J. 2003. — Diversity of rodents and shrews along an elevational gradient in Bwindi Impenetrable National Park, south-western Uganda. African Journal of Ecology 41: 115-123. https://doi.org/10.1046/J.1365-2028.2003.00383.X.

Klempa B., FicheT-Calvet E., Lecompte E., Auste B., Aniskin V., Meisel H., Barrière P., Koivogui L., ter Meulen J. \& KRÜGER D. H. 2007. - Novel hantavirus sequences in shrew, Guinea. Emerging Infectious Diseases 13: 520-522. https://doi. org/10.3201/eid1303.061198

LamotTe M. \& Roy R. 2003. — Le peuplement animal du Mont Nimba (Guinée, Côte d'Ivoire, Libéria). Publications scientifiques du Muséum National d'Histoire Naturelle, Paris, 724 p., 1 CD-Rom.

Lavrenchenko L. A., Milishnikov A. N., Aniskin V. M., WarSHAVSKY A. A. \& GEBREKIDAN W. 1997. - The genetic diversity of small mammals of the Bale mountains, Ethiopia. Sinet: Ethiopian Journal of Science 20 (2): 213-223.

LEE M. R. \& ELDER F. F.B. 1980. — Yeast stimulation of bone marrow mitosis for cytogenetic investigations. Cytogenetics and Cell Genetics 26: 36-40.

MadDAlena T. \& Ruedi M. 1994. - Chromosomal evolution in the genus Crocidura Soricidae, Insectivora), in MERRITT F. J., KirKLAND G. L. \& Rose R. K. (eds), Advances in the Biology of Shrews, Special Publication of The Carnegie Museum of Natural History Pittsburgh, Vol.18: 335-344.

Maddalena T., Mehmeti A. M., Bronner G. \& Vogel P. 1987. The karyotype of Crocidura flavescens (Mammalia, Insectivora) in South Africa. Zeitschrift für Säugetierkunde 52: 129-132.

Mamba M. L., Dalton D. L., Mahlaba T. A.M., KropfF A. S. \& Monadjem A. 2021. - Small mammals of a West African hotspot, the Ziama-Wonegizi-Wologizi Transfrontier forest landscape. Mammalia 85: 127-144. https://doi.org/10.1515/ mammalia-2020-0013.

MeYlan A. 1967. - La formule chromosomique de Crocidura occidentalis kivu Osgood (Mammalia-Isectivora). Revue Suisse de Zoologie 74: 685-691.

MeYlan A. 1971. - Chromosomes de Soricidés de Côte d'Ivoire (Mammalia, Insectivore). Revue suisse de Zoologie 78: 603-613.

MeYlan A. \& Vogel P. 1982. — Contribution à la cytotaxonomie des Soricidés (Mammalia: Insectivora) de l'Afrique occidentale. Cytogenetics and Cell Genetics 34: 83-92.
Monadjem A., Richards L., Taylor P. J. \& STOFFberg S. 2013. High diversity of pipistrelloid bats (Vespertilionidae: Hypsugo, Neoromicia, and Pipistrellus) in a West African rainforest with the description of a new species. Zoological Journal of the Linnean Society 67: 191-207. https://doi.org/10.1111/j.1096-3642.2012.00871.x

Monadjem A., Richards L. \& Denys C. 2016. - An African bat hotspot: the importance of Mount Nimba for bat diversity. Acta Chiropterologia 18: 359-375. https://doi.org/10.3161/1508110 9ACC2016.18.2.005

Monadjem A., Decher J., Crawley W.-Y. \& McCleery R. A. 2019. - The conservation status of a poorly known rangerestricted mammal, the Nimba otter-shrew Micropotamogale lamottei. Mammalia 83: 1-10. https://doi.org/10.1515/mammalia-2017-0144

Monadjem A., Richards L. R., Decher J., Hutterer R., Mamba M. L., Guyton J., Naskrecki P., Markotter W., Wipfler B., KropfF A. S. \& Dalton D. L. 2021. - A phylogeny for African Pipistrellus species with the description of a new species from West Africa (Mammalia: Chiroptera). Zoological Journal of the Linnean Society 191: 548-574. https://doi.org/10.1093/ zoolinnean/zlaa068

Myers N., Mittermeier R. A., Mittermeier C. G., Da Fonseca G. A. B. \& KENT J. 2000. - Biodiversity hotspots for conservation priorities. Nature 403: 853-858. https://doi.org/10.1038/35002501.

NiCOLAS V., BARRIÈRE P. \& COLYN M. 2005. - Seasonal variation in population and community structure of shrews in a tropical forest of Gabon. Journal of Tropical Ecology 21: 161-169.

Nicolas V., Barrière P., TAPiero A. \& Colyn M. 2009. — Shrew species diversity and abundance in Ziama Biosphere Reserve (Guinea): comparison between primary forest, degraded forest and restoration plots. Biodiversity and Conservation 18: 20432061. https://doi.org/10.1007/s10531-008-9572-4

Nicolas V., Jacquet F., Hutterer R., Konecny A., Kouasssi Kan S., Durnez L., Lalis A., Colyn M. \& Denys C. 2019. Multi-locus phylogeny of the Crocidura poensis species complex (Mammalia, Eulipotyphla): Influences of the paleoclimate on its diversification and evolution. Journal of Biogeography 46 (5): 871-883. https://doi.org/10.1111/jbi.13534

Nicolas V., Gerbault-Seureau M., Delapre A. \& Bed'Hom B. 2020. - Small mammals inventory in the Lama Forest reserve (south Benin), with new cytogenetical data. Journal of Vertebrate Biology 69 (2): 20009. https://doi.org/10.25225/jvb.20009

Quérouil S., Barrière P., Colyn M., Hutterer R., Dudu A., Dillen M. \& VerheYen E. 2005. - A molecular insight into the systematics of African Crocidura (Crocidurinae, Soricidae) using 16s rRNA sequences, in MERRITT J. F., CHURCHFiELd S., HutTerer R. \& SHeftel B. I. (eds), Advances in the biology of shrews II (International Society of Shrew Biologists, Special Publication 1, New York, USA: 99-113.

RÁCz G. \& DeMETER A. 1998. - Character displacement in mandible shape and size in two species of water shrews (Neomys, Mammalia: Insectivora). Acta Zoologica Academiae Scientiarum Hungaricae 44: 165-175.

RAY J. C. \& HutTerer R. 1996. - Structure of a shrew community in the Central African Republic based on the analysis of carnivore scats, with a description of a new Sylvisorex (Mammalia: Soricidae). Ecotropica 1: 85-97.

SCHILTHUIZEN M. 2000. - Ecotone: speciation-prone. Trends in Ecology and Evolution 15: 130-131. https://doi.org/10.1016/ S0169-5347(00)01839-5

Schlitter D. A., Hutterer R., Maddalena T., Robbins L. W. 1999. - New karyotypes of shrews (Mammalia: Soricidae) from Cameroon and Somalia. Annals of Carnegie Museum 68: 1-14.

Sikes R. S. \& The Animal Care and Use Committee of the American Society of Mammalogists 2016. — Guidelines of the American Society of Mammalogists for the use of wild mammals in research and education. Journal of Mammalogy 97: 663-688. https://doi.org/10.1093/jmammal/gyw078 
STANLEY W. \& OlsOn L. 2005. — Phylogeny, phylogeography, and geographic variation of Sylvisorex howelli (Soricidae), an endemic shrew of the Eastern Arc Mountains, Tanzania. Journal of Zoology, London 266: 341-354. https://doi.org/10.1111/ZOJ.12230

STANLEY W. \& ESSELSTYN J. 2010. — Biogeography and diversity among montane populations of mouse shrew (Soricidae: Myosorex) in Tanzania. Biological Journal of the Linnean Society 100: 669-680. https://doi.org/10.1111/j.1095-8312.2010.01448.x

TAYlor P. J., DenYs C. \& CotTerill F. P. D. 2019. — Taxonomic anarchy or an inconvenient truth for conservation: accelerated species discovery reveals evolutionary processes and patterns and heightened extinction threat in African small mammals. Mammalia 83: 313-329. https://doi.org/10.1515/mammalia-2018-0031

Van de Perre F., Leirs H., Cigar J., Gambalemoke Mbalitini S. MukinZI ITOKA J.-C. \& VERHEYEN E. 2019. — Shrews (Soricidae) of the lowland forests around Kisangani (DR Congo). Biodiversity Data Journal 7: e46948. https://doi.org/10.3897/BDJ.7.e4694

Verschuren J. \& Meester J. 1977. — Notes sur les Soricidae (Insectivora) du Nimba Libérien. Mammalia 41: 291-299.
Vogel P., Vogel V., Fumagalli L., Kadjo B., Kouadio R. Y. \& DUBEY S. 2014. - Genetic identity of the critically endangered Wimmer's shrew Crocidura wimmeri. Biological Journal of the Linnean Society 111: 224-229. https://doi.org/10.1111/ bij. 12196

WHITE F. 1981. - The history of the Afromontane archipelago and the scientific need for its conservation. African Journal of Ecology 19: 33-54.

Wilson D. E. \& Mittermeier R. A. eds 2018. - Handbook of the Mammals of the World. Vol.8. Insectivores, sloths and colugos. Lynx Edicions, Barcelona: 1-709 p.

Wojcik J. M., Bogdanowicz W., PuceK Z., WójciK A. M. \& ZALEWSKA H. 2000. - Morphometric variation of the common shrew Sorex araneus in Poland, in relation to karyotype. Acta Theriologica 45: 161-172.

Wótcik J. M., Borodin P. M., Fedyk S., Fredga K., Hausser J., Mishta A., Orlov V. N., Searle J. B., Volobouev V. T. \& ZIMA J. 2003. - The list of chromosome races of the common shrew Sorex araneus. Mammalia 68: 169-178.

Submitted on 5 October 2020; accepted on 20 April 2021; published on 30 November 2021. 


\section{APPENDICES}

APPENDIX 1. - Shrew specimens from Guinean Mount Nimba collected and used in this study with MNHN collection and field numbers, habitat, sex, weight (g) and external body measurements (mm). Expedition number: 1, February-March 2008, 2, October 2008 and 3, December $2009-J a n u a r y ~ 2010$ (used for Table 5 and 6). Abbreviations: Alt. savannah, Altitude savannah and see Material and methods.

\begin{tabular}{|c|c|c|c|c|c|c|c|c|c|c|c|c|c|c|}
\hline \multirow{2}{*}{$\begin{array}{l}\text { Collection } \\
\text { number } \\
\text { (MNHN-ZM-) }\end{array}$} & \multirow{2}{*}{$\begin{array}{l}\text { Field } \\
\text { number }\end{array}$} & \multirow[b]{2}{*}{ Species } & \multirow[b]{2}{*}{ Locality } & \multirow[b]{2}{*}{ Habitat } & \multirow{2}{*}{\multicolumn{3}{|c|}{$\begin{array}{l}\text { Altitude Mission } \\
\text { (m asl) number Sex }\end{array}$}} & \multirow[b]{2}{*}{$\mathbf{W}$} & \multirow[b]{2}{*}{ HB } & \multirow[b]{2}{*}{ TL } & \multirow[b]{2}{*}{ HF } & & $\begin{array}{l}\text { Specimens } \\
\text { for morph } \\
\text { analyses }\end{array}$ & $\begin{array}{l}\text { s used } \\
\text { nometric }\end{array}$ \\
\hline & & & & & & & & & & & & $\mathbf{E}^{\mathbf{E}}$ & $\begin{array}{l}\text { Body } \\
\text { measures }\end{array}$ & $\begin{array}{l}\text { Skull } \\
\text { distances }\end{array}$ \\
\hline 2012-1051 & G221 & C. buettikoferi & Gbié & Gallery forest & 573 & 2 & M & 17 & 96 & 59 & 15 & 7 & $x$ & $x$ \\
\hline $2012-1052$ & G227 & C. buettikoferi & Gbié & Gallery forest & 612 & 2 & M & 14 & 83 & 62 & 15 & 7 & $x$ & $x$ \\
\hline 2012-1053 & G241 & C. buettikoferi & Gbié & Gallery forest & 612 & 2 & $\mathrm{~F}$ & 9 & 86 & 56 & 14 & 7 & $x$ & $x$ \\
\hline 2012-1054 & G248 & C. buettikoferi & Gbié & Gallery forest & 552 & 2 & M & 15 & 96 & 60 & 15 & 7 & $x$ & $x$ \\
\hline 2012-1055 & GBE90 & C. buettikoferi & Gblayougouma & Secondary forest & 477 & 3 & $M$ & 14 & 91 & 60 & 17 & 8 & $x$ & - \\
\hline $2012-1056$ & N320 & C. buettikoferi & Gouan & Gallery forest & 1212 & 1 & $\mathrm{~F}$ & 19 & 98 & 64 & 16 & 9 & $x$ & $x$ \\
\hline 2012-1057 & N323 & C. buettikoferi & Gouan & Gallery forest & 1212 & 1 & M & 19 & 78 & 57 & 17 & 9 & $x$ & $x$ \\
\hline $2012-1058$ & NIMII01 & C. buettikoferi & Gouan & Alt. savannah & 1616 & 2 & M & 10 & 75 & 54 & 15 & 7 & $x$ & $x$ \\
\hline 2012-1059 & NIMII02 & C. buettikoferi & Gouan & Alt. savannah & 1616 & 2 & $\mathrm{~F}$ & 10 & 77 & 57 & 15 & 7 & $x$ & - \\
\hline $2012-1060$ & NIMII07 & C. buettikoferi & Gouan & Alt. savannah & 1616 & 2 & $\mathrm{~F}$ & 18 & 100 & 56 & 15 & 8 & $x$ & $x$ \\
\hline 2012-1061 & NIMII12 & C. buettikoferi & Gouan & Alt. savannah & 1616 & 2 & $\mathrm{~F}$ & 10 & 82 & 56 & 15 & 8 & $x$ & $\times$ \\
\hline 2012-1062 & NIMII17 & C. buettikoferi & Gouan & Alt. savannah & 1616 & 2 & $F$ & 14 & 93 & 53 & 15 & 7 & $x$ & $x$ \\
\hline 2012-1063 & NIMII18 & C. buettikoferi & Gouan & Alt. savannah & 1616 & 2 & $\mathrm{~F}$ & 12 & 90 & 64 & 15 & 7 & $x$ & $x$ \\
\hline $2012-1064$ & NIMII20 & C. buettikoferi & Gouan & Gallery forest & 1206 & 2 & $\mathrm{~F}$ & 15 & 101 & 60 & 16 & 8 & $x$ & $x$ \\
\hline 2012-1065 & NIMII21 & C. buettikoferi & Gouan & Gallery forest & 1206 & 2 & $\mathrm{~F}$ & 16 & 99 & 62 & 15 & 7 & $x$ & $x$ \\
\hline 2012-1066 & NIMII59 & C. buettikoferi & Gouan & Gallery forest & 1176 & 2 & $\mathrm{M}$ & 15 & 98 & 68 & 16 & 8 & $x$ & $x$ \\
\hline 2012-1067 & NIMII72 & C. buettikoferi & Gouan & Alt. savannah & 1616 & 2 & M & 17 & 95 & 61 & 15 & 7 & $x$ & $x$ \\
\hline 2012-1068 & N71 & C. buettikoferi & Serengbara & Secondary forest & 600 & 1 & $\mathrm{~F}$ & 13 & 86 & 52 & 15 & 7 & $x$ & $x$ \\
\hline $2012-1069$ & SER160 & C. buettikoferi & Serengbara & Secondary forest & 589 & 2 & M & 18 & 96 & 58 & 15 & 8 & $x$ & $x$ \\
\hline 2012-1070 & SER184 & C. buettikoferi & Serengbara & Secondary forest & 589 & 2 & $\mathrm{~F}$ & 10 & 86 & 55 & 15 & 7 & $x$ & $x$ \\
\hline 2012-1071 & SER185 & C. buettikoferi & Serengbara & Secondary forest & 589 & 2 & M & 14 & 98 & 57 & 16 & 8 & $x$ & $x$ \\
\hline 2012-1072 & N329 & C. buettikoferi & Ziéla & Gallery forest & 581 & 1 & $\mathrm{~F}$ & 18 & 99 & 66 & 16 & 7 & $x$ & $x$ \\
\hline 2012-1074 & ZIE256 & C. buettikoferi & Ziéla & Gallery forest & 581 & - & I & - & - & - & - & - & - & $x$ \\
\hline 2012-1075 & SER156 & C. douceti & Serengbara & Secondary forest & 589 & 2 & I & - & - & - & - & - & - & $x$ \\
\hline 2012-1076 & G209 & C. grandiceps & Gbié & Gallery forest & 612 & 2 & M & 14 & 104 & 84 & 20 & 9 & $x$ & $x$ \\
\hline 2012-1077 & G220 & C. grandiceps & Gbié & Gallery forest & 573 & 2 & M & 12 & 92 & 53 & 15 & 7 & $x$ & $\times$ \\
\hline 2012-1078 & N172 & C. grandiceps & Gbié & Gallery forest & 608 & 1 & $\mathrm{~F}$ & 13 & 95 & 56 & 14 & 7 & $x$ & $x$ \\
\hline- & N191 & C. grandiceps & Gbié & Savannah & 649 & 1 & $F$ & 12 & 106 & 72 & 19 & 8 & $x$ & - \\
\hline 2012-1079 & N217 & C. grandiceps & Gouan & Gallery forest & 1212 & 1 & M & 30 & 102 & 73 & 21 & 11 & $x$ & $x$ \\
\hline $2012-1080$ & N266 & C. grandiceps & Gouan & Gallery forest & 1212 & 1 & $\mathrm{~F}$ & 16.5 & 96 & 85 & 18 & 8 & $x$ & $x$ \\
\hline 2012-1081 & N305 & C. grandiceps & Gouan & Gallery forest & 1212 & 1 & $\mathrm{M}$ & 23 & 95 & 85 & 19 & 8 & $x$ & $x$ \\
\hline 2012-1082 & NIMII63 & C. grandiceps & Gouan & Gallery forest & 1206 & 2 & $\mathrm{~F}$ & 23 & 99 & 77 & 20 & 9 & $x$ & $x$ \\
\hline 2012-1083 & ZIE10 & C. grandiceps & Ziéla & Secondary forest & 477 & 3 & $\mathrm{~F}$ & 16 & 117 & 80 & 20 & 10 & $x$ & - \\
\hline 2012-1084 & ZIE40 & C. grandiceps & Ziéla & Secondary forest & 477 & 3 & M & 25 & 118 & 114 & 21 & 11 & $x$ & - \\
\hline 2012-1085 & ZIE41 & C. grandiceps & Ziéla & Secondary forest & 477 & 3 & $\mathrm{~F}$ & 21 & 112 & 70 & 20 & 11 & $x$ & - \\
\hline 2012-1086 & G212 & C. jouvenetae & Gbié & Gallery forest & 552 & 2 & $\mathrm{~F}$ & 9 & 79 & 53 & 10 & 7 & $x$ & $x$ \\
\hline 2012-1087 & G214 & C. jouvenetae & Gbié & Gallery forest & 552 & 2 & $\mathrm{~F}$ & 6 & 70 & 47 & 12 & 7 & $x$ & $x$ \\
\hline 2012-1088 & G218 & C. jouvenetae & Gbié & Gallery forest & 552 & 2 & $\mathrm{~F}$ & 6 & 71 & 46 & 11 & 6 & $x$ & $x$ \\
\hline 2012-1089 & G224 & C. jouvenetae & Gbié & Gallery forest & 612 & 2 & $\mathrm{~F}$ & 5 & 70 & 49 & 12 & 7 & $x$ & $x$ \\
\hline 2012-1090 & G226 & C. jouvenetae & Gbié & Gallery forest & 612 & 2 & $\mathrm{M}$ & 8 & 76 & 51 & 10 & 7 & $x$ & $x$ \\
\hline 2012-1091 & G229 & C. jouvenetae & Gbié & Gallery forest & 552 & 2 & M & 8 & 75 & 49 & 10 & 7 & $x$ & $x$ \\
\hline 2012-1092 & G232 & C. jouvenetae & Gbié & Gallery forest & 552 & 2 & $\mathrm{~F}$ & 5 & 69 & 44 & 10 & 6 & $x$ & $\times$ \\
\hline $2012-1093$ & N177 & C. jouvenetae & Gbié & Savannah & 649 & 1 & $M$ & 8 & 74 & 50 & 13 & 7 & $x$ & $x$ \\
\hline 2012-1094 & N178 & C. jouvenetae & Gbié & Savannah & 649 & 1 & $\mathrm{~F}$ & 7 & 80 & 49 & 12 & 8 & $x$ & $x$ \\
\hline 2012-1095 & N267 & C. jouvenetae & Gouan & Gallery forest & 1212 & 1 & M & 6.5 & 73 & 46 & 12 & 7 & $x$ & $x$ \\
\hline 2012-1096 & N280 & C. jouvenetae & Gouan & Alt. savannah & 1642 & 1 & $\mathrm{~F}$ & 5 & 61 & 46 & 10 & 6 & $x$ & $x$ \\
\hline 2012-1097 & NIMII29 & C. jouvenetae & Gouan & Gallery forest & 1176 & 2 & $\mathrm{~F}$ & 7 & 69 & 48 & 8 & 6 & $x$ & $x$ \\
\hline 2012-1098 & N288 & C. jouvenetae & Gouan & Alt. savannah & 1642 & 1 & 1 & - & - & - & - & - & - & $x$ \\
\hline 2012-1099 & N1 & C. jouvenetae & Serengbara & Secondary forest & 589 & 1 & $\mathrm{M}$ & - & 75 & 56 & 12.5 & 59 & $x$ & $x$ \\
\hline $2012-1100$ & N2 & C. jouvenetae & Serengbara & Secondary forest & 589 & 1 & M & 6.5 & 56 & 48 & 12.5 & 57 & $x$ & $x$ \\
\hline 2012-1101 & N34 & C. jouvenetae & Serengbara & Secondary forest & 589 & 1 & M & 7 & 68 & 56 & 13.5 & 57.5 & $x$ & $x$ \\
\hline 2012-1102 & N35 & C. jouvenetae & Serengbara & Secondary forest & 589 & 1 & $\mathrm{~F}$ & 4 & 60 & 40 & 12 & 8.5 & $x$ & $x$ \\
\hline 2012-1103 & N4 & C. jouvenetae & Serengbara & Secondary forest & 589 & 1 & $\mathrm{M}$ & 5.5 & 65 & 49 & 12.5 & 59 & $x$ & $x$ \\
\hline- & N322 & C. jouvenetae & Gouan & Gallery forest & 1212 & 1 & $\mathrm{~F}$ & 7 & 70 & 47 & 12 & 7 & $x$ & - \\
\hline 2012-1104 & SER150 & C. jouvenetae & Serengbara & Secondary forest & 589 & 2 & $\mathrm{M}$ & 8 & 67 & 46 & 12 & 7 & $x$ & $x$ \\
\hline 2012-1105 & SER151 & C. jouvenetae & Serengbara & Secondary forest & 589 & 2 & $\mathrm{~F}$ & 8 & 75 & 51 & 12 & 7 & $x$ & $x$ \\
\hline 2012-1106 & SER152 & C. jouvenetae & Serengbara & Secondary forest & 589 & 2 & $\mathrm{~F}$ & 6 & 73 & 45 & 11 & 7 & $x$ & $x$ \\
\hline 2012-1107 & SER155 & C. jouvenetae & Serengbara & Secondary forest & 589 & 2 & $\mathrm{~F}$ & 6 & 71 & 47 & 11 & 7 & $x$ & $x$ \\
\hline 2012-1108 & G205 & C. muricauda & Gbié & Gallery forest & 552 & 2 & I & - & - & - & - & - & - & $x$ \\
\hline 2012-1109 & N156 & C. muricauda & Gbié & Savannah & 649 & 1 & $\mathrm{~F}$ & 6 & 69 & 82 & 13 & 7 & $x$ & $x$ \\
\hline $2012-1110$ & N228 & C. muricauda & Gouan & Gallery forest & 1212 & 1 & $\mathrm{~F}$ & 5 & 61 & 73 & 11 & 7 & $x$ & $x$ \\
\hline 2012-1111 & N232 & C. muricauda & Gouan & Gallery forest & 1212 & 1 & $\mathrm{M}$ & 5.5 & 66 & 81 & 12 & 7 & $x$ & $x$ \\
\hline
\end{tabular}




\begin{tabular}{|c|c|c|c|c|c|c|c|c|c|c|c|c|c|c|}
\hline \multirow{2}{*}{$\begin{array}{l}\text { Collection } \\
\text { number } \\
\text { (MNHN-ZM-) }\end{array}$} & \multirow{2}{*}{$\begin{array}{l}\text { Field } \\
\text { number }\end{array}$} & \multirow[b]{2}{*}{ Species } & \multirow[b]{2}{*}{ Locality } & \multirow[b]{2}{*}{ Habitat } & \multirow{2}{*}{\multicolumn{2}{|c|}{$\begin{array}{l}\text { Altitude Mission } \\
\text { (m asl) number }\end{array}$}} & \multirow[b]{2}{*}{ rSex } & \multirow[b]{2}{*}{ w } & \multirow[b]{2}{*}{ HB } & & & & $\begin{array}{l}\text { Specimens } \\
\text { for morph } \\
\text { analyses }\end{array}$ & $\begin{array}{l}\text { Is used } \\
\text { hometric }\end{array}$ \\
\hline & & & & & & & & & & TL & HF & E & $\begin{array}{l}\text { Body } \\
\text { measures }\end{array}$ & $\begin{array}{l}\text { Skull } \\
\text { s distances } \\
\end{array}$ \\
\hline $2012-1112$ & N319 & C. muricauda & Gouan & Gallery forest & 1212 & 1 & $\mathrm{~F}$ & 5 & 53 & 76 & 12 & 7 & $x$ & $x$ \\
\hline $2012-1113$ & N238 & C. muricauda & Gouan & Gallery forest & 1212 & 1 & I & - & - & - & - & - & - & $x$ \\
\hline $2012-1114$ & N263 & C. muricauda & Gouan & Gallery forest & 1212 & 1 & 1 & - & - & - & - & - & - & $x$ \\
\hline $2012-1115$ & G236 & C. nimbasilvanus & sGbié & Gallery forest & 552 & 2 & $M$ & 51 & 148 & 120 & 25 & 14 & $x$ & $x$ \\
\hline $2012-1116$ & G193 & C. obscurior & Gbié & Gallery forest & 552 & 2 & $\mathrm{~F}$ & 4 & 57 & 37 & 10 & 6 & $x$ & $x$ \\
\hline $2012-1117$ & G194 & C. obscurior & Gbié & Gallery forest & 552 & 2 & $\mathrm{~F}$ & 4 & 59 & 33 & 10 & 6 & $x$ & - \\
\hline $2012-1118$ & G206 & C. obscurior & Gbié & Gallery forest & 612 & 2 & $\mathrm{~F}$ & 3 & 58 & 34 & 10 & - & - & $x$ \\
\hline $2012-1119$ & G225 & C. obscurior & Gbié & Gallery forest & 612 & 2 & $\mathrm{~F}$ & 4 & 64 & 32 & 8 & 7 & $x$ & $x$ \\
\hline $2012-1120$ & G228 & C. obscurior & Gbié & Gallery forest & 612 & 2 & M & 3 & 52 & 37 & 9 & 6 & $x$ & $x$ \\
\hline $2012-1121$ & N179 & C. obscurior & Gbié & Savannah & 649 & 1 & $M$ & 4 & 60 & 33 & 10 & 6 & $x$ & $x$ \\
\hline $2012-1122$ & GBE89 & C. obscurior & Gblayougouma & Secondary forest & 477 & 3 & M & 4 & 59 & 33 & 11 & 6 & $x$ & - \\
\hline $2012-1123$ & N219 & C. obscurior & Gouan & Gallery forest & 1212 & 1 & M & 5 & 57 & 33 & 10 & 6 & $x$ & - \\
\hline $2012-1124$ & N237 & C. obscurior & Gouan & Gallery forest & 1212 & 1 & $\mathrm{~F}$ & 3.5 & 58 & 33 & 8 & 7 & $x$ & $x$ \\
\hline $2012-1125$ & N239 & C. obscurior & Gouan & Alt. savannah & 1642 & 1 & M & 3 & 58 & 30 & 8 & 6 & $x$ & $x$ \\
\hline $2012-1126$ & N282 & C. obscurior & Gouan & Gallery forest & 1212 & 1 & M & 4 & 50 & 33 & 9 & 7 & $x$ & $x$ \\
\hline $2012-1127$ & N294 & C. obscurior & Gouan & Gallery forest & 1212 & 1 & $M$ & 3 & 47 & 35 & 10 & 5 & $x$ & $x$ \\
\hline $2012-1128$ & N296 & C. obscurior & Gouan & Gallery forest & 1212 & 1 & M & 3.5 & 49 & 39 & 9 & 5 & $x$ & $x$ \\
\hline $2012-1129$ & N307 & C. obscurior & Gouan & Gallery forest & 1212 & 1 & $\mathrm{M}$ & 4 & 48 & 35 & 10 & 6 & $x$ & - \\
\hline $2012-1130$ & NIMII06 & C. obscurior & Gouan & Alt. savannah & 1616 & 2 & $\mathrm{M}$ & 4 & 59 & 29 & 8 & 6 & $x$ & $x$ \\
\hline $2012-1131$ & NIMII09 & C. obscurior & Gouan & Alt. savannah & 1616 & 2 & $\mathrm{M}$ & 5 & 60 & 37 & 10 & 6 & $\hat{x}$ & $\hat{x}$ \\
\hline $2012-1132$ & NIMII15 & C. obscurior & Gouan & Gallery forest & 1176 & 2 & M & 3 & 54 & 34 & 10 & 6 & $x$ & $x$ \\
\hline $2012-1133$ & NIMII16 & C. obscurior & Gouan & Gallery forest & 1176 & 2 & $\mathrm{~F}$ & 4 & 60 & 30 & 10 & 6 & $x$ & $x$ \\
\hline $2012-1134$ & NIMII25 & C. obscurior & Gouan & Alt. savannah & 1616 & 2 & $M$ & 4 & 56 & 32 & 9 & 6 & $x$ & $x$ \\
\hline $2012-1135$ & NIMII41 & C. obscurior & Gouan & Gallery forest & 1176 & 2 & $\mathrm{~F}$ & 3 & 57 & 35 & 9 & 6 & $x$ & $x$ \\
\hline $2012-1136$ & N72 & C. obscurior & Serengbara & Secondary forest & 589 & 1 & $\mathrm{~F}$ & 3 & 51 & 32 & 9 & 5 & $x$ & $x$ \\
\hline - & SER145 & C. obscurior & Serengbara & Secondary forest & 589 & 2 & $\mathrm{~F}$ & 3 & 46 & 38 & 8 & 6 & $\hat{x}$ & _- \\
\hline $2012-1137$ & SER153 & C. obscurior & Serengbara & Secondary forest & 589 & 2 & $\mathrm{~F}$ & 4 & 56 & 34 & 8 & 6 & $x$ & $x$ \\
\hline $2012-1138$ & SER154 & C. obscurior & Serengbara & Secondary forest & 589 & 2 & $M$ & 4 & 58 & 35 & 9 & 6 & $x$ & $x$ \\
\hline 2012-1139 & SER157 & C. obscurior & Serengbara & Secondary forest & 589 & 2 & $\mathrm{~F}$ & 4 & 56 & 32 & 8 & 5 & $x$ & $x$ \\
\hline $2012-1140$ & SER158 & C. obscurior & Serengbara & Secondary forest & 589 & 2 & M & 4 & 58 & 35 & 8 & 6 & $x$ & $x$ \\
\hline- & SER171 & C. obscurior & Serengbara & Secondary forest & 589 & 2 & $\mathrm{~F}$ & 4 & 55 & 35 & 9 & 6 & $x$ & - \\
\hline 2012-1141 & ZIE24 & C. obscurior & Ziela & Secondary forest & 477 & 3 & $M$ & 4 & 54 & 35 & 10 & 6 & $\hat{x}$ & - \\
\hline $2012-1142$ & ZIE38 & C. obscurior & Ziela & Secondary forest & 477 & 3 & M & 4 & 59 & 32 & 11 & 6 & $x$ & - \\
\hline $2012-1143$ & ZIE39 & C. obscurior & Ziela & Secondary forest & 477 & 3 & $\mathrm{~F}$ & 4 & 63 & 31 & 10 & 6 & $x$ & - \\
\hline $2012-1145$ & ZIE47 & C. obscurior & Ziéla & Secondary forest & 477 & 3 & $\mathrm{~F}$ & 4 & 58 & 31 & 9 & 6 & $x$ & _- \\
\hline $2012-1146$ & ZIE48 & C. obscurior & Ziéla & Secondary forest & 477 & 3 & M & 5 & 61 & 37 & 10 & 7 & $x$ & - \\
\hline $2012-1148$ & N281 & C. obscurior & Gouan & Gallery forest & 1212 & 1 & 1 & - & - & - & - & - & - & $x$ \\
\hline 2012-1149 & N295 & C. obscurior & Gouan & Gallery forest & 1212 & 1 & i & _- & _- & _- & - & - & - & $\hat{x}$ \\
\hline $2012-1150$ & N312 & C. obscurior & Gouan & Alt. savannah & 1642 & 1 & 1 & - & - & - & - & - & - & $x$ \\
\hline $2012-1151$ & N316 & C. obscurior & Gouan & Alt. savannah & 1642 & 1 & i & - & - & - & - & - & - & $x$ \\
\hline $2012-1152$ & G201 & C. olivieri & Gbié & Savannah & 596 & 2 & $\mathrm{~F}$ & 26 & 123 & 65 & 19 & 10 & $x$ & $x$ \\
\hline $2012-1153$ & G203 & C. olivieri & Gbié & Gallery forest & 552 & 2 & M & 10 & 103 & 73 & 18 & 9 & $x$ & $x$ \\
\hline $2012-1154$ & G208 & C. olivieri & Gbié & Gallery forest & 552 & 2 & $\mathrm{~F}$ & 27 & 119 & 103 & 17 & 7 & $x$ & $x$ \\
\hline 2012-1155 & G239 & C. olivieri & Gbié & Gallery forest & 573 & 2 & $M$ & 31 & 116 & 81 & 20 & 12 & $x$ & $x$ \\
\hline $2012-1156$ & G243 & C. olivieri & Gbié & Gallery forest & 612 & 2 & M & 24 & 114 & 80 & 18 & 8 & $x$ & $x$ \\
\hline $2012-1157$ & N162 & C. olivieri & Gbié & Gallery forest & 621 & 1 & $\mathrm{~F}$ & 33 & 122 & 89 & 22 & 10 & $x$ & $x$ \\
\hline $2012-1158$ & N201 & C. olivieri & Gbié & Gallery forest & 608 & 1 & $\mathrm{~F}$ & 24 & 123 & 76 & 20 & 8 & $x$ & $x$ \\
\hline 2012-1159 & GBE57 & C. olivieri & Gblayougouma & Secondary forest & 477 & 3 & M & 35 & 132 & 73 & 20 & 11 & $x$ & - \\
\hline $2012-1160$ & GBE59 & C. olivieri & Gblayougoun & Secondary forest & 477 & 3 & $\mathrm{~F}$ & 24 & 120 & 73 & 18 & 9 & $x$ & - \\
\hline $2012-1161$ & N321 & C. olivieri & Gouan & Gallery forest & 1212 & 1 & $M$ & 30 & 124 & 80 & 22 & 8 & $x$ & $x$ \\
\hline $2012-1162$ & NIMII57 & C. olivieri & Gouan & Gallery forest & 1176 & 2 & $\mathrm{~F}$ & 16 & 111 & 78 & 18 & 11 & $x$ & $x$ \\
\hline $2012-1163$ & NIMII58 & C. olivieri & Gouan & Gallery forest & 1176 & 2 & M & 34 & 132 & - & 20 & 10 & - & $x$ \\
\hline 2012-1164 & SER159 & C. olivieri & Serengbara & Secondary forest & 589 & 2 & $M$ & 22 & 116 & 78 & 20 & 9 & $x$ & $x$ \\
\hline 2012-1167 & G200 & C. theresae & Gbié & Gallery forest & 573 & 2 & $\mathrm{M}$ & 23 & 92 & 53 & 15 & 7 & $x$ & $x$ \\
\hline $2012-1168$ & G202 & C. theresae & Gbié & Savannah & 595 & 2 & $\mathrm{M}$ & 10 & 84 & 51 & 12 & 7 & $x$ & $x$ \\
\hline 2012-1169 & G238 & C. theresae & Gbié & Gallery forest & 573 & 2 & $\mathrm{~F}$ & 13 & 83 & 47 & 12 & 7 & $x$ & $x$ \\
\hline $2012-1170$ & G242 & C. theresae & Gbié & Gallery forest & 612 & 2 & $\mathrm{~F}$ & 13 & 88 & 45 & 12 & 7 & $x$ & $x$ \\
\hline $2012-1171$ & G244 & C. theresae & Gbié & Savannah & 595 & 2 & $\mathrm{~F}$ & 15 & 89 & 49 & 14 & 8 & $x$ & $x$ \\
\hline 2012-1172 & N155 & C. theresae & Gbié & Savannah & 628 & 1 & $\mathrm{~F}$ & 10 & 90 & 54 & 15 & 8 & $x$ & $x$ \\
\hline $2012-1173$ & N157 & C. theresae & Gbié & Savannah & 628 & 1 & $\mathrm{M}$ & 75 & 89 & 60 & 14 & 7 & $x$ & $x$ \\
\hline $2012-1174$ & N164 & C. theresae & Gbié & Gallery forest & 608 & 1 & $\mathrm{~F}$ & 10 & 97 & 48 & 12 & 7 & $x$ & $x$ \\
\hline 2012-1176 & N240 & C. theresae & Gouan & Alt. savannah & 1642 & 1 & $\mathrm{~F}$ & 12.5 & 82 & 50 & 13 & 8 & $x$ & $x$ \\
\hline 2012-1177 & N241 & C. theresae & Gouan & Alt. savannah & 1642 & 1 & $\mathrm{~F}$ & 9 & 86 & 51 & 14 & 7 & $x$ & $x$ \\
\hline $2012-1178$ & N250 & C. theresae & Gouan & Alt. savannah & 1642 & 1 & $M$ & - & 83 & 54 & 14 & 7 & $x$ & $x$ \\
\hline
\end{tabular}




\begin{tabular}{|c|c|c|c|c|c|c|c|c|c|c|c|c|c|c|}
\hline \multirow{2}{*}{$\begin{array}{l}\text { Collection } \\
\text { number } \\
\text { (MNHN-ZM-) }\end{array}$} & \multirow{2}{*}{$\begin{array}{l}\text { Field } \\
\text { number }\end{array}$} & \multirow[b]{2}{*}{ Species } & \multirow[b]{2}{*}{ Locality } & \multirow[b]{2}{*}{ Habitat } & \multirow{2}{*}{\multicolumn{2}{|c|}{$\begin{array}{l}\text { Altitude Mission } \\
\text { ( } m \text { asl) number }\end{array}$}} & \multirow[b]{2}{*}{ Sex } & \multirow[b]{2}{*}{ W } & \multirow[b]{2}{*}{ HB } & \multirow[b]{2}{*}{ TL } & \multirow[b]{2}{*}{ HF } & \multicolumn{3}{|c|}{$\begin{array}{l}\text { Specimens used } \\
\text { for morphometric } \\
\text { analyses }\end{array}$} \\
\hline & & & & & & & & & & & & E & $\begin{array}{l}\text { Body } \\
\text { measures }\end{array}$ & $\begin{array}{l}\text { Skull } \\
\text { s distances }\end{array}$ \\
\hline 2012-1179 & N252 & C. theresae & Gouan & Alt. savannah & 1642 & 1 & M & 12.5 & 82 & 60 & 13 & 8 & $x$ & $x$ \\
\hline $2012-1180$ & N301 & C. theresae & Gouan & Alt. savannah & 1639 & 1 & $\mathrm{~F}$ & 14 & 86 & 59 & 15 & 8 & $x$ & $x$ \\
\hline 2012-1181 & N302 & C. theresae & Gouan & Alt. savannah & 1642 & 1 & $\mathrm{~F}$ & 12.5 & 93 & 51 & 13 & 8 & $x$ & $x$ \\
\hline 2012-1182 & N303 & C. theresae & Gouan & Alt. savannah & 1642 & 1 & M & 14 & 81.5 & 52 & 16 & 8 & $x$ & $x$ \\
\hline $2012-1183$ & N311 & C. theresae & Gouan & Alt. savannah & 1642 & 1 & $\mathrm{M}$ & 16 & 86 & 60 & 13 & 8 & $x$ & $x$ \\
\hline $2012-1184$ & N313 & C. theresae & Gouan & Savannah & 1236 & 1 & M & 15 & 87 & 50 & 14 & 7 & $x$ & $x$ \\
\hline 2012-1185 & NIMII122 & C. theresae & Gouan & Gallery forest & 1201 & 2 & $\mathrm{~F}$ & 9 & 78 & 53 & 15 & 7 & $x$ & - \\
\hline $2012-1186$ & NIMII43 & C. theresae & Gouan & Alt. savannah & 1616 & 2 & $\mathrm{~F}$ & 14 & 88 & 50 & 14 & 7 & $x$ & $x$ \\
\hline 2012-1187 & NIMII52 & C. theresae & Gouan & Alt. savannah & 1616 & 2 & $\mathrm{M}$ & 16 & 87 & 51 & 15 & 8 & $x$ & $x$ \\
\hline 2012-1188 & NIMII70 & C. theresae & Gouan & Alt. savannah & 1616 & 2 & $\mathrm{~F}$ & 10 & 75 & 53 & 15 & 7 & $x$ & $x$ \\
\hline $2012-1189$ & NIMII82 & C. theresae & Gouan & Alt. savannah & 1616 & 2 & $\mathrm{M}$ & 10 & 85 & 52 & 15 & 7 & $x$ & $x$ \\
\hline 2012-1190 & G237 & S. megalura & Gbié & Gallery forest & 552 & 2 & $\mathrm{~F}$ & 7 & 76 & 82 & 14 & 7 & $x$ & $x$ \\
\hline 2012-1191 & N163 & S. megalura & Gbié & Savannah & 621 & 1 & $\mathrm{M}$ & 6 & 76 & 90 & 15 & 7 & $x$ & $x$ \\
\hline 2012-1192 & N242 & S. megalura & Gouan & Alt. savannah & 1642 & 1 & $\mathrm{~F}$ & 5 & 67 & 84 & 14 & 7 & $x$ & $x$ \\
\hline $2012-1193$ & N244 & S. megalura & Gouan & Alt. savannah & 1642 & 1 & $\mathrm{M}$ & 5.5 & 71 & 80 & 13 & 7 & $x$ & $x$ \\
\hline 2012-1194 & N292 & S. megalura & Gouan & Alt. savannah & 1642 & 1 & $\mathrm{M}$ & 5 & 63 & 75 & 13 & 7 & $x$ & $x$ \\
\hline $2012-1195$ & N306 & S. megalura & Gouan & Gallery forest & 1212 & 1 & $\mathrm{M}$ & 6 & 60 & 83 & 15 & 7 & $x$ & $x$ \\
\hline 2012-1196 & NIMIIO3 & S. megalura & Gouan & Alt. savannah & 1616 & 2 & $\mathrm{M}$ & 8 & 68 & 87 & 15 & 7 & $x$ & - \\
\hline 2012-1197 & NIMIIO4 & S. megalura & Gouan & Alt. savannah & 1616 & 2 & M & 8 & 75 & 81 & 15 & 7 & $x$ & - \\
\hline $2012-1198$ & NIMII08 & S. megalura & Gouan & Alt. savannah & 1616 & 2 & $\mathrm{~F}$ & 8 & 70 & 70 & 14 & 7 & $x$ & - \\
\hline 2012-1199 & NIMII10 & S. megalura & Gouan & Alt. savannah & 1616 & 2 & $\mathrm{~F}$ & 6 & 68 & 83 & 13 & 7 & $x$ & - \\
\hline $2012-1200$ & NIMII11 & S. megalura & Gouan & Alt. savannah & 1616 & 2 & $\mathrm{~F}$ & 5 & 68 & 80 & 15 & 7 & $x$ & - \\
\hline $2012-1201$ & NIMII26 & S. megalura & Gouan & Alt. savannah & 1616 & 2 & $\mathrm{~F}$ & 7 & 71 & 82 & 15 & 7 & $x$ & - \\
\hline 2012-1202 & NIMII40 & S. megalura & Gouan & Alt. savannah & 1616 & 2 & $\mathrm{~F}$ & 3 & 57 & 60 & 13 & 6 & $x$ & - \\
\hline $2012-1203$ & NIMII54 & S. megalura & Gouan & Alt. savannah & 1616 & 2 & $\mathrm{~F}$ & 8 & 71 & 88 & 14 & 7 & $x$ & - \\
\hline 2012-1204 & NIMII55 & S. megalura & Gouan & Alt. savannah & 1616 & 2 & $\mathrm{~F}$ & 9 & 72 & 84 & 15 & 7 & $x$ & - \\
\hline 2012-1205 & NIMII56 & S. megalura & Gouan & Alt. savannah & 1616 & 2 & $\mathrm{~F}$ & 8 & 68 & 76 & 15 & 7 & $x$ & - \\
\hline
\end{tabular}


APPENDIX 2. - Shrew specimens from Liberian Mount Nimba we collected and used in this study with DM and MNHN collection and field numbers, habitat, sex, weight $(\mathrm{g})$ and external body measurements $(\mathrm{mm})$. Expedition number: 1, December 2011; 2, February-March 2013. Abbreviations: see Material and methods.

\begin{tabular}{|c|c|c|c|c|c|c|c|c|c|c|c|c|c|c|}
\hline \multirow{2}{*}{$\begin{array}{l}\text { Collection } \\
\text { number } \\
\text { (DM/ ou } \\
\text { MNHN-ZM- }\end{array}$} & \multirow{2}{*}{ Field number } & \multirow[b]{2}{*}{ Species } & \multirow[b]{2}{*}{ Locality } & \multirow[b]{2}{*}{ Habitat } & \multirow{2}{*}{\multicolumn{3}{|c|}{$\begin{array}{l}\text { Altitude Mission } \\
\text { (m) number Sex }\end{array}$}} & \multirow[b]{2}{*}{$\mathrm{W}$} & \multirow[b]{2}{*}{ HB } & \multirow[b]{2}{*}{ TL } & \multirow[b]{2}{*}{ HF } & \multirow[b]{2}{*}{$\mathbf{E}$} & \multicolumn{2}{|c|}{$\begin{array}{c}\text { Specimens used } \\
\text { for morphometric } \\
\text { analyses }\end{array}$} \\
\hline & & & & & & & & & & & & & $\begin{array}{l}\text { Body } \\
\text { measures }\end{array}$ & $\begin{array}{l}\text { Skull } \\
\text { s distances } \\
\end{array}$ \\
\hline DM13179 & AM2011_12_27_ & 3C. theresae & ENNR 11 & Savannah & 1350 & 1 & $\mathrm{M}$ & 11.5 & 83 & 55 & 14.9 & 8 & $x$ & $x$ \\
\hline DM13180 & AM2011_12_27_ & 2C. theresae & ENNR 11 & Savannah & 1350 & 1 & $\mathrm{~F}$ & 10.5 & 79 & 51 & 14.6 & 8 & $x$ & $x$ \\
\hline DM13176 & AM2012_01_10_ & 1 C. nimbasilvanus & Bentor 1 & Lowland forest & 420 & 1 & $\mathrm{M}$ & 48.5 & 137 & 117 & 24.6 & 14 & $x$ & $x$ \\
\hline DM13182 & AM2012_01_10_ & 2C. jouvenetae & Bentor 1 & Lowland forest & 420 & 1 & $\mathrm{~F}$ & 7.2 & 76 & 50 & 12.7 & 9 & $x$ & $x$ \\
\hline DM13183 & AM2011_12_29_ & 1C. muricauda & ENNR 15 & Mountain forest & 1064 & 1 & $\mathrm{~F}$ & 4.5 & 64 & 90 & 11.9 & 7 & $x$ & $x$ \\
\hline DM13184 & AM2012_01_11_ & 2C. muricauda & Bentor 1 & Lowland forest & 420 & 1 & $\mathrm{~F}$ & 4.6 & 64 & 71 & 12.4 & 8 & $x$ & $x$ \\
\hline DM13190 & AM2011_12_23_ & 2C. muricauda & Tailings 2 & Lowland forest & 475 & 1 & $?$ & 4 & 61 & 58 & 12.1 & 9 & $x$ & $x$ \\
\hline DM13185 & AM2012_01_09_ & $\begin{array}{l}\text { 3C. obscuriorl } \\
\text { eburnea }\end{array}$ & Bentor 1 & Lowland forest & 420 & 1 & $\mathrm{~F}$ & 3.5 & 58 & 38 & 9.9 & 7 & - & - \\
\hline DM13186 & AM2012_01_09_ & 4C. eburnea & Bentor 1 & Lowland forest & 420 & 1 & $\mathrm{~F}$ & 4.8 & 62 & 37 & 10.6 & 8 & $x$ & $x$ \\
\hline DM13187 & AM2011_12_30_ & $\begin{array}{l}\text { 1C. obscurior/ } \\
\text { eburnea }\end{array}$ & ENNR 15 & Mountain forest & 1064 & 1 & $\mathrm{~F}$ & 2.9 & 62 & 35 & 10.3 & 7 & $\times$ & - \\
\hline DM13188 & AM2012_01_11_ & 3C. eburnea & Bentor 1 & Lowland forest & 420 & 1 & $\mathrm{~F}$ & 2.5 & 56 & 35 & 10.5 & 7 & $x$ & $x$ \\
\hline DM13196 & AM2011_12_25_ & $\begin{array}{l}\text { 1C. obscurior/ } \\
\text { eburnea }\end{array}$ & Tailings 2 & Lowland forest & 475 & 1 & M & 2.7 & 51 & 39 & 10.1 & 6 & - & - \\
\hline DM13197 & AM2011_12_28_ & 1C. eburnea & ENNR 14 & Mountain forest & 1188 & 1 & $\mathrm{~F}$ & 3.3 & 64 & 29 & 10.7 & 7 & $x$ & $x$ \\
\hline DM13198 & AM2012_01_09_ & 5C. eburnea & Bentor 1 & Lowland forest & 420 & 1 & M & 4.5 & 65 & 40 & 10.9 & 8 & $x$ & $x$ \\
\hline DM13199 & AM2012_01_09_ & 6C. eburnea & Bentor 1 & Lowland forest & 420 & 1 & M & 4.1 & 65 & 40 & 10.7 & 8 & $x$ & $x$ \\
\hline DM13200 & AM2012_01_02_ & $\begin{array}{l}\text { 1C. obscurior/ } \\
\text { eburnea }\end{array}$ & ENNR 15 & Mountain forest & 1064 & 1 & M & 3.8 & 65 & 38 & 11,0 & 7 & $x$ & - \\
\hline DM13201 & AM2012_01_09_ & 2C. eburnea & Bentor 1 & Lowland forest & 420 & 1 & $\mathrm{M}$ & 3.1 & 61 & 37 & 10.9 & 7 & $x$ & $x$ \\
\hline DM13202 & AM2012_01_09_ & $\begin{array}{l}\text { 1C. obscurior/ } \\
\text { eburnea }\end{array}$ & Bentor 1 & Lowland forest & 420 & 1 & M & 3.1 & 61 & 35 & 10.9 & 8 & - & - \\
\hline DM13203 & AM2011_12_23_ & $\begin{array}{l}\text { 1C. obscurior/ } \\
\text { eburnea }\end{array}$ & Tailings 2 & Lowland forest & 475 & 1 & M & 3.9 & 62 & 39 & 10.8 & 7 & - & - \\
\hline DM13177 & AM2011_12_22_ & 3C. olivieri & Tailings 4 & Lowland forest & 494 & 1 & $\mathrm{M}$ & 29.5 & 122 & 79 & 20.8 & 12 & $x$ & $x$ \\
\hline DM13189 & AM2011_12_22_ & 1C. olivieri & Tailings 4 & Lowland forest & 494 & 1 & $\mathrm{~F}$ & 33 & 119 & 71 & 18.8 & 11 & $x$ & $x$ \\
\hline DM13204 & AM2011_12_18_ & 1C. olivieri & Tailings 1 & Lowland forest & 381 & 1 & $\mathrm{~F}$ & 25.5 & 109 & 75 & 20,0 & 13 & $x$ & $x$ \\
\hline Released & & C. olivieri & Tailings 4 & Lowland forest & 494 & 1 & $\mathrm{M}$ & & & & 20.7 & & - & - \\
\hline Released & & C. olivieri & Tailings 7 & Lowland forest & 467 & 1 & $?$ & & & & 21.5 & & - & - \\
\hline Released & & C. olivieri & ENNR 16 & Lowland forest & 690 & 1 & $\mathrm{M}$ & & & & 21,0 & & - & - \\
\hline Released & & C. olivieri & Tailings 4 & Lowland forest & 494 & 1 & $\mathrm{~F}$ & & & & 20.7 & & - & - \\
\hline Released & & C. olivieri & Bonlah 2 & $\begin{array}{l}\text { Secondary } \\
\text { forest }\end{array}$ & 452 & 1 & $\mathrm{M}$ & & & & 20.6 & & - & - \\
\hline DM13181 & AM2012_01_11_ & 1 C. buettikoferi & Bentor 1 & Lowland forest & 420 & 1 & M & 17.5 & 97 & 69 & 16,0 & 11 & $x$ & $\times$ \\
\hline DM13178 & AM2012_01_05_ & 1S. megalura & $\begin{array}{l}\text { Settlement } \\
6\end{array}$ & $\begin{array}{l}\text { Secondary } \\
\text { forest }\end{array}$ & 515 & 1 & $\mathrm{M}$ & 6.1 & 70 & 87 & 15.3 & 9 & $x$ & $x$ \\
\hline 2014-899 & LBO3 & C. buettikoferi & Camp4 & Gallery forest & 516 & 2 & $\mathrm{~F}$ & 12 & 98 & 56 & 15 & 9 & $x$ & - \\
\hline $2014-900$ & LB07 & C. buettikoferi & Camp4 & Gallery forest & 515 & 2 & $\mathrm{~F}$ & 14 & 105 & 58 & 15 & 10 & $x$ & - \\
\hline 2014-912 & LB09 & C. grandiceps & Camp4 & Gallery forest & 516 & 2 & $\mathrm{~F}$ & 9 & 91 & 46 & 15 & 19 & $x$ & - \\
\hline 2014-913 & LB12 & C. grandiceps & Camp4 & Gallery forest & 516 & 2 & $\mathrm{~F}$ & 13 & 98 & 53 & 15 & 9 & $x$ & - \\
\hline 2014-939 & LB20 & C. olivieri & Grassfield & Bush, fallow & 498 & 2 & $\mathrm{~F}$ & 16 & 110 & 65 & 17 & 10 & $x$ & - \\
\hline $2014-914$ & LB28 & C. grandiceps & Zolowee & Houses & 458 & 2 & M & 25 & 114 & 88 & 19 & 10 & $x$ & - \\
\hline 2014-934 & LB38 & C. olivieri & Grassfield & Savannah & 476 & 2 & $M$ & 33 & 119 & 72 & 17 & 10 & $x$ & - \\
\hline 2014-935 & LB42 & C. olivieri & Grassfield & Savannah & 476 & 2 & M & 32 & 120 & 71 & 19 & 11 & $x$ & - \\
\hline 2014-936 & LB54 & C. olivieri & Grassfield & Bush, fallow & 498 & 2 & M & 38 & 130 & 81 & 19 & 12 & $x$ & - \\
\hline $2014-925$ & LB59 & C. muricauda & Liabala & Gallery forest & 470 & 2 & $\mathrm{~F}$ & 5 & 67 & 78 & 11 & 9 & $x$ & - \\
\hline 2014-918 & LB60 & C. jouvenetae & Liabala & Gallery forest & 470 & 2 & $\mathrm{~F}$ & 7.5 & 74 & 44 & 10 & 8 & $x$ & - \\
\hline 2014-909 & LB61 & C. eburnea & Liabala & Gallery forest & 470 & 2 & $\mathrm{~F}$ & 4.2 & 68 & 32 & 10 & 6 & $x$ & - \\
\hline $2014-927$ & LB62 & C. obscurior & Liabala & Gallery forest & 470 & 2 & M & 3.6 & 60 & 35 & 9 & 7 & $x$ & - \\
\hline 2014-928 & LB63 & C. obscurior & Liabala & Gallery forest & 470 & 2 & $\mathrm{~F}$ & 3 & 62 & 38 & 9 & 7 & $x$ & - \\
\hline 2014-919 & LB71 & C. jouvenetae & Liabala & Gallery forest & 470 & 2 & $\mathrm{~F}$ & 6.7 & 76 & 44 & 10 & 7 & $x$ & - \\
\hline 2014-929 & LB75 & C. obscurior & Camp4 & Gallery forest & 516 & 2 & $\mathrm{~F}$ & 3 & 59 & 36 & 9 & 5 & $x$ & - \\
\hline 2014-920 & LB76 & C. jouvenetae & Camp4 & Gallery forest & 516 & 2 & $\mathrm{~F}$ & 6 & 77 & 55 & 11 & 7 & $x$ & - \\
\hline 2014-905 & LB78 & C. buettikoferi & Camp4 & Gallery forest & 516 & 2 & $\mathrm{M}$ & 15 & 100 & 68 & 14 & 7 & $x$ & - \\
\hline $2014-930$ & LB79 & C. obscurior & Liabala & Gallery forest & 470 & 2 & $\mathrm{~F}$ & 3.5 & 60 & 38 & 8 & 6 & $x$ & - \\
\hline $2014-910$ & LB80 & C. eburnea & Liabala & Gallery forest & 470 & 2 & $\mathrm{~F}$ & 5.5 & 71 & 40 & 9 & 6 & $x$ & - \\
\hline 2014-911 & LB81 & C. eburnea & Liabala & Gallery forest & 470 & 2 & $\mathrm{~F}$ & 5.5 & 70 & 34 & 9 & 5 & $x$ & - \\
\hline 2014-931 & LB82 & C. obscurior & Liabala & Gallery forest & 470 & 2 & $\mathrm{~F}$ & 4.5 & 68 & 35 & 8 & 6 & $x$ & - \\
\hline 2014-921 & LB83 & C. jouvenetae & Liabala & Gallery forest & 470 & 2 & $M$ & 6.5 & 75 & 40 & 10 & 8 & $x$ & - \\
\hline 2014-906 & LB106 & C. eburnea & Camp4 & Gallery forest & 516 & 2 & $\mathrm{~F}$ & 3.3 & 59 & 39 & 9 & 5 & $x$ & - \\
\hline $2014-917$ & LB108 & C. buettikoferi & Liabala & Gallery forest & 470 & 2 & $\mathrm{~F}$ & 12 & 88 & 58 & 14 & 8 & $x$ & - \\
\hline 2014-907 & LB109 & C. eburnea & Liabala & Gallery forest & 470 & 2 & $\mathrm{~F}$ & 3.4 & 63 & 33 & 9 & 6 & $x$ & - \\
\hline 2014-941 & LB115 & C. theresae & Camp4 & Gallery forest & 516 & 2 & $\mathrm{M}$ & 8.6 & 78 & 54 & 14 & 7 & $x$ & - \\
\hline
\end{tabular}




\begin{tabular}{|c|c|c|c|c|c|c|c|c|c|c|c|c|c|c|}
\hline \multirow{2}{*}{$\begin{array}{l}\text { Collection } \\
\text { number } \\
\text { (DM/ ou } \\
\text { MNHN-ZM-) }\end{array}$} & \multirow{2}{*}{-)Field number } & \multirow[b]{2}{*}{ Species } & \multirow[b]{2}{*}{ Locality } & \multirow[b]{2}{*}{ Habitat } & \multirow{2}{*}{\multicolumn{2}{|c|}{$\begin{array}{l}\text { Altitude Mission } \\
\text { (m) number }\end{array}$}} & \multirow[b]{2}{*}{ Sex } & \multirow[b]{2}{*}{$\mathbf{w}$} & \multirow[b]{2}{*}{ HB } & \multirow[b]{2}{*}{ TL } & \multirow[b]{2}{*}{ HF } & \multicolumn{3}{|c|}{$\begin{array}{c}\text { Specimens used } \\
\text { for morphometric } \\
\text { analyses }\end{array}$} \\
\hline & & & & & & & & & & & & E & $\begin{array}{l}\text { Body } \\
\text { measures }\end{array}$ & $\begin{array}{l}\text { Skull } \\
\text { s distances }\end{array}$ \\
\hline 2014-932 & LB116 & C. obscurior & Gbapa & $\begin{array}{l}\text { Secondary } \\
\text { forest }\end{array}$ & 441 & 2 & $F$ & 3.5 & 55 & 39 & 8 & 6 & $x$ & - \\
\hline 2014-901 & LB122 & C. buettikoferi & Gbapa & Gallery forest & 460 & 2 & $\mathrm{~F}$ & 12 & 96 & 64 & 14 & 8 & $x$ & - \\
\hline 2014-915 & LB129 & C. grandiceps & Zolowee & Houses & 458 & 2 & $\mathrm{~F}$ & 14 & 101 & 50 & 14 & 7 & $x$ & - \\
\hline 2014-902 & LB130 & C. buettikoferi & Liabala & Gallery forest & 470 & 2 & $\mathrm{~F}$ & 11 & 93 & 60 & 14 & 8 & $x$ & - \\
\hline 2014-937 & LB131 & C. olivieri & Gbapa & Gallery forest & 474 & 2 & M & 23 & 113 & 78 & 14 & 9 & $x$ & - \\
\hline 2014-938 & LB138 & C. olivieri & Gbapa & Gallery forest & 460 & 2 & M & 31 & 123 & 71 & 18 & 9 & $x$ & - \\
\hline 2014-922 & LB142 & C. jouvenetae & Gbapa & $\begin{array}{l}\text { Secondary } \\
\text { forest }\end{array}$ & 441 & 2 & $\mathrm{~F}$ & 7.6 & 80 & 46 & 12 & 7 & $x$ & - \\
\hline 2014-923 & LB143 & C. jouvenetae & Gbapa & $\begin{array}{l}\text { Secondary } \\
\text { forest }\end{array}$ & 441 & 2 & M & 6 & 64 & 39 & 10 & 6 & $x$ & - \\
\hline $2014-903$ & LB150 & C. buettikoferi & Camp4 & Gallery forest & 516 & 2 & $\mathrm{~F}$ & 17 & 101 & 61 & 15 & 9 & $x$ & - \\
\hline $2014-926$ & LB151 & C. muricauda & Liabala & Gallery forest & 470 & 2 & $\mathrm{~F}$ & 5 & 71 & 118 & 11 & 7 & $x$ & - \\
\hline 2014-916 & LB152 & C. grandiceps & $\begin{array}{l}\text { Cap4_- } \\
\text { marais }\end{array}$ & Swamp & 491 & 2 & $\mathrm{~F}$ & 17 & 94 & 58 & 16 & 8 & $x$ & - \\
\hline $2014-940$ & LB162 & C. olivieri & Border & Savannah & 542 & 2 & $F 3$ & 30.4 & 135 & 73 & 18 & 10 & $x$ & - \\
\hline 2014-942 & LB170 & C. theresae & Border & Savannah & 542 & 2 & $\mathrm{~F}$ & 15 & 95 & 48 & 14 & 8 & $x$ & - \\
\hline 2014-924 & LB171 & C. jouvenetae & Liabala & Gallery forest & 470 & 2 & M & 5 & 71 & 48 & 10 & 5 & $x$ & - \\
\hline $2014-933$ & LB172 & C. obscurior & Liabala & Gallery forest & 470 & 2 & $\mathrm{~F}$ & 3.5 & 64 & 38 & 10 & & $x$ & - \\
\hline 2014-908 & LB173 & C. eburnea & Liabala & Gallery forest & 470 & 2 & $\mathrm{~F}$ & 3.5 & 65 & 36 & 9 & 5 & $x$ & - \\
\hline \multirow[t]{2}{*}{ 2014-904 } & LB177 & C. buettikoferi & Border & $\begin{array}{l}\text { Secondary } \\
\text { forest }\end{array}$ & 569 & 2 & $\mathrm{~F}$ & 13 & 94 & 59 & 13 & 8 & $x$ & - \\
\hline & LB25 & S. megalura & Camp4 & Gallery forest & 516 & 2 & $\mathrm{~F}$ & 6.5 & 73 & 84 & 14 & 7 & $x$ & - \\
\hline
\end{tabular}


APPENDIX 3. - Shrew specimens from the Guinean and Ivorian surroundings of Mount Nimba used in this study with MNHN collection and field numbers (when available) for CVA analyses, sex, weight ( $\mathrm{g}$ ) and external body measurements ( $\mathrm{mm}$ ). Holotypes and paratypes in bold, Type specimens available in the collections of the Muséum National d'Histoire Naturelle, all described by Heim de Balsac in 1956 and 1958. *Specimens initially described as subspecies of C. bottegi (Heim de Balsac 1959) but later elevated to full species level (Hutterer 2005, Jacquet et al. 2014)). Abbreviations: see Material and methods.

\begin{tabular}{|c|c|c|c|c|c|c|c|c|c|c|c|}
\hline \multirow{2}{*}{$\begin{array}{l}\text { Collection } \\
\text { number (MNHN- } \\
\text { ZM-MO-/ } \\
\text { MNHN-ZM-) }\end{array}$} & \multirow{2}{*}{$\begin{array}{l}\text { Field } \\
\text { number }\end{array}$} & \multirow[b]{2}{*}{ Species } & \multirow[b]{2}{*}{$\begin{array}{l}\text { Locality/ } \\
\text { Country }\end{array}$} & \multirow[b]{2}{*}{ Sex } & \multirow[b]{2}{*}{ W } & \multirow[b]{2}{*}{ HB } & \multirow[b]{2}{*}{ TL } & \multirow[b]{2}{*}{ HF } & \multirow[b]{2}{*}{$\mathbf{E}$} & \multicolumn{2}{|c|}{$\begin{array}{l}\text { Specimens used for } \\
\text { morphometric analyses }\end{array}$} \\
\hline & & & & & & & & & & $\begin{array}{c}\text { Body } \\
\text { measures }\end{array}$ & $\begin{array}{c}\text { Skull } \\
\text { distances }\end{array}$ \\
\hline $1981-498$ & - & C. theresae & Nzérékoré, Mt Nimba & M & - & 60 & 40 & 12 & - & - & $x$ \\
\hline $1981-499$ & - & C. theresae & Nzérékoré, Mt Nimba & $\mathrm{F}$ & - & - & - & - & - & - & $x$ \\
\hline $1981-490$ & - & C. jouvenetae & Ziéla, Mt Nimba & M & - & 60 & 40 & 12 & - & - & - \\
\hline 1981-492 & - & C. nimbae & Zouguépo, Mt Nimba & $\mathrm{F}$ & - & 90 & 57 & 17 & - & - & $x$ \\
\hline $1981-493$ & - & C. nimbae & Zouguépo, Mt Nimba & M & - & 80 & 52 & 16 & - & - & - \\
\hline $1981-494$ & - & C. obscurior* & Gouéla, Mt Nimba & M & - & 50 & 37 & 10 & - & - & - \\
\hline 1981-495 & - & C. obscurior* & Ziéla, Mt Nimba & M & - & - & - & - & - & - & - \\
\hline $1981-482$ & - & C. obscurior* & Zouguépo, Mt Nimba & - & - & - & - & - & - & - & - \\
\hline $1981-483$ & - & C. eburnea* & Mt Toukoui (Côte d'Ivoire) & $\mathrm{F}$ & - & 40 & 28 & 9 & - & - & - \\
\hline $1981-496$ & - & C. obscurior & Altitude grassland, Mt Nimba & $\mathrm{F}$ & - & - & - & - & - & - & - \\
\hline 1984-1099 & - & C. douceti & Adiopodoumé (Côte d'Ivoire) & $\mathrm{F}$ & - & 55 & 50 & 11.5 & - & - & - \\
\hline $2013-755$ & $\mathrm{BH} 5$ & C. buettikoferi & Bhoita & M & 17 & 97 & 67 & 17 & 10 & $x$ & $x$ \\
\hline $2012-1436$ & $\mathrm{Cl} 418$ & C. buettikoferi & Touzouko (Côte d'Ivoire) & M & 13 & 94 & 57 & 11 & 10 & $x$ & $\times$ \\
\hline 2013-770 & FR47 & C. buettikoferi & Franfina & $\mathrm{F}$ & 17 & 100 & 57 & 17 & 10 & $x$ & $x$ \\
\hline 2013-771 & FR51 & C. buettikoferi & Franfina & $\mathrm{F}$ & 11 & 91 & 51 & 15 & 10 & $x$ & $x$ \\
\hline 2013-772 & FR53 & C. buettikoferi & Franfina & M & 13 & 92 & 58 & 16 & 10 & $x$ & $x$ \\
\hline $2013-763$ & GUI137 & C. buettikoferi & Gbetlaya & M & 15 & 94 & 61 & 15 & 8 & $x$ & $x$ \\
\hline 2013-773 & GUI1374 & C. buettikoferi & Gania & $M$ & 21 & 108 & 62 & 17 & 10 & $x$ & $x$ \\
\hline 2013-774 & GUI1431 & C. buettikoferi & Gania & $\mathrm{F}$ & 17 & 93 & 60 & 18 & 9 & $x$ & $x$ \\
\hline 2013-742 & GUI448 & C. buettikoferi & Tanganya & $M$ & 16 & 103 & 64 & 16 & 10 & $\times$ & $x$ \\
\hline $2013-743$ & GUI791 & C. buettikoferi & Tanganya & M & 11 & 92 & 51 & 17 & 9 & $x$ & $x$ \\
\hline 2013-745 & MK29 & C. buettikoferi & Maikou & $\mathrm{F}$ & 11 & 87 & 52 & 15 & 11 & $x$ & $x$ \\
\hline $2013-747$ & MK33 & C. buettikoferi & Maikou & $M$ & 14 & 98 & 66 & 17 & 9 & $x$ & $x$ \\
\hline $2013-748$ & SA17 & C. buettikoferi & Sangassou & M & 15 & 93 & 67 & 10 & 9 & $x$ & $x$ \\
\hline $2013-749$ & SA20 & C. buettikoferi & Sangassou & $M$ & 16 & 106 & 75 & 17 & 9 & $x$ & $\times$ \\
\hline $2013-750$ & SA21 & C. buettikoferi & Sangassou & $\mathrm{M}$ & 14 & 100 & 60 & 16 & 10 & $x$ & $x$ \\
\hline $2013-751$ & SA28 & C. buettikoferi & Sangassou & M & 16 & 102 & 68 & 16 & 9 & $x$ & $x$ \\
\hline $2013-752$ & SA32 & C. buettikoferi & Sangassou & $\mathrm{F}$ & 14 & 96 & 62 & 16 & 10 & $x$ & $x$ \\
\hline $2013-753$ & SA36 & C. buettikoferi & Sangassou & $M$ & 16 & 102 & 70 & 17 & 10 & $x$ & $x$ \\
\hline 2013-489 & VN1379 & C. douceti & Zogota & $\mathrm{F}$ & 49 & 60 & 11 & 9 & 5 & $x$ & $x$ \\
\hline $2017-28$ & P0953 & C. douceti & Zogota & $M$ & 58 & 61 & 13 & 9 & 6 & $x$ & $x$ \\
\hline $2017-31$ & P1556 & C. douceti & Zogota & M & 61 & 61 & 12 & 9 & 4 & $x$ & $x$ \\
\hline $2017-47$ & P2687 & C. douceti & Zogota & $\mathrm{F}$ & 60 & 60 & 60 & 10 & 6 & $x$ & $x$ \\
\hline 2017-37 & P2274 & C. douceti & Zogota & $\mathrm{F}$ & 63 & 60 & 12 & - & 5 & $x$ & $x$ \\
\hline 2017-69 & P1572 & C. douceti & Zogota & $\mathrm{F}$ & 62 & 58 & 12 & 9 & 5 & $x$ & $x$ \\
\hline $2017-70$ & P1612 & C. douceti & Zogota & $M$ & 63 & 67 & 13 & 10 & 6 & $\times$ & $x$ \\
\hline $2017-107$ & P0958 & C. douceti & Zogota & $M$ & 49 & 60 & 11 & 9 & 5 & $x$ & $x$ \\
\hline 2017-108 & P0967 & C. douceti & Ziama & $M$ & 4 & 54 & 55 & 13 & 7 & $x$ & $x$ \\
\hline $2017-115$ & P1097 & C. douceti & Ziama & $\mathrm{F}$ & 5 & 82 & 59 & 12 & 10 & $x$ & $x$ \\
\hline $2017-117$ & P1233 & C. douceti & Ziama & M & 5 & 65 & 57 & 12 & 10 & $x$ & $x$ \\
\hline- & DV0056 & C. obscurior & Ziama/Diecke & - & - & - & - & - & - & - & $x$ \\
\hline- & P0842 & C. eburnea & Ziama/Diecke & $M$ & 4 & 56 & 41 & 11 & 8 & $x$ & $x$ \\
\hline- & PO955 & C. eburnea & Ziama/Diecke & M & 6 & 65 & 41 & 12 & 10 & $x$ & $x$ \\
\hline $2013-777$ & $\mathrm{BH} 20$ & C. grandiceps & Bhoita & $\mathrm{F}$ & 22 & 109 & 82 & 16 & 13 & $x$ & $x$ \\
\hline 2013-769 & FR43 & C. grandiceps & Franfina & M & 16 & 95 & 64 & 17 & 9 & $x$ & $x$ \\
\hline 2013-781 & YRD14 & C. grandiceps & Yerende & $\mathrm{F}$ & 10 & 85 & 54 & 14 & 7 & $x$ & $x$ \\
\hline $2012-1477$ & Cl199 & C. jouvenetae & Gbaboube & $\mathrm{F}$ & 8 & 82 & 50 & 12 & 7 & $x$ & $x$ \\
\hline 2013-791 & GUI919 & C. jouvenetae & Bantou & $M$ & 8 & 78 & 47 & 11 & 7 & $x$ & $x$ \\
\hline 2013-805 & GUI1336 & C. jouvenetae & Tanganya & $\mathrm{F}$ & 11 & 66 & 45 & 11 & 6 & $x$ & $x$ \\
\hline 2013-792 & GUI157 & C. jouvenetae & Gbetlaya & $M$ & 7 & 79 & 52 & 12 & 9 & $x$ & $x$ \\
\hline 2013-793 & GUI816 & C. jouvenetae & Tanganya & $\mathrm{M}$ & 6 & 74 & 49 & 11 & 8 & $x$ & $x$ \\
\hline- & $\mathrm{BH} 22$ & C. muricauda & Bhoita & $M$ & 7 & 74 & 96 & 16 & 10 & $x$ & $x$ \\
\hline 2013-589 & VN1282 & C. muricauda & Zogota & $\mathrm{F}$ & 3 & 68 & 78 & 10 & 6 & $x$ & $x$ \\
\hline $2013-569$ & VN1281 & C. muricauda & Zogota & $\mathrm{F}$ & 4.5 & 69 & 64 & 11 & 7 & $x$ & $x$ \\
\hline 2013-571 & VN1416 & C. muricauda & Zogota & $\mathrm{F}$ & 4 & 69 & 71 & 12 & 8 & $x$ & $x$ \\
\hline $2017-438$ & PO872 & C. nimbae & Ziama & $\mathrm{F}$ & 22 & 92 & 61 & 16 & 10 & $x$ & $x$ \\
\hline $2017-437$ & PO839 & C. nimbae & Ziama & $M$ & 17 & 86 & 51 & 17 & 11 & $x$ & $x$ \\
\hline $2017-412$ & P2963 & C. nimbae & Ziama & $\mathrm{F}$ & 25 & 100 & 62 & 17 & 12 & $x$ & $x$ \\
\hline $2017-441$ & P2668 & C. nimbae & Ziama & $\mathrm{M}$ & 16 & 99 & 59 & 17 & 10 & $x$ & $x$ \\
\hline $2017-440$ & P1597 & C. nimbae & Ziama & $\mathrm{F}$ & 21 & 102 & 60 & 16 & 10 & $x$ & $x$ \\
\hline 2017-439 & P0947 & C. nimbae & Ziama & $M$ & 16 & 88 & 65 & 17 & 11 & $\times$ & $\times$ \\
\hline $2017-443$ & P1829 & C. nimbae & Ziama & $\mathrm{F}$ & 12 & 85 & 55 & 15 & 11 & $\times$ & $\times$ \\
\hline 2017-374 & P0265 & C. nimbasilvanu & sZiama & $M$ & 52 & 137 & 123 & 25 & 15 & $x$ & $x$ \\
\hline
\end{tabular}


Appendix 3. - Continuation.

\begin{tabular}{|c|c|c|c|c|c|c|c|c|c|c|c|}
\hline \multirow{2}{*}{$\begin{array}{l}\text { Collection } \\
\text { number (MNHN- } \\
\text { ZM-MO-/ } \\
\text { MNHN-ZM-) }\end{array}$} & \multirow{2}{*}{$\begin{array}{l}\text { Field } \\
\text { number }\end{array}$} & \multirow[b]{2}{*}{ Species } & \multirow[b]{2}{*}{$\begin{array}{l}\text { Locality/ } \\
\text { Country }\end{array}$} & \multirow[b]{2}{*}{ Sex } & \multirow[b]{2}{*}{$\mathbf{W}$} & \multirow[b]{2}{*}{ HB } & \multirow[b]{2}{*}{ TL } & \multirow[b]{2}{*}{ HF } & \multirow[b]{2}{*}{$\mathbf{E}$} & \multicolumn{2}{|c|}{$\begin{array}{l}\text { Specimens used for } \\
\text { morphometric analyses }\end{array}$} \\
\hline & & & & & & & & & & $\begin{array}{c}\text { Body } \\
\text { measures }\end{array}$ & $\begin{array}{c}\text { Skull } \\
\text { distances }\end{array}$ \\
\hline $2017-377$ & PO452 & C. nimbasilvanus & sZiama & $\mathrm{M}$ & 54 & 104 & 114 & 21 & 14 & $x$ & $x$ \\
\hline 2017-378 & PO461 & C. nimbasilvanus & sZiama & $\mathrm{M}$ & 53 & 136 & 115 & 25 & 15 & $x$ & $x$ \\
\hline $2017-380$ & PO484 & C. nimbasilvanus & sZiama & $\mathrm{F}$ & 52 & 130 & 113 & 22 & 16 & $x$ & $x$ \\
\hline 2017-382 & PO594 & C. nimbasilvanus & sZiama & $\mathrm{F}$ & 63 & 129 & 117 & 23 & 15 & $x$ & $x$ \\
\hline $2017-383$ & PO693 & C. nimbasilvanus & sZiama & $\mathrm{M}$ & 59 & 123 & 115 & 24 & 12 & $x$ & $x$ \\
\hline 2017-384 & PO747 & C. nimbasilvanus & sZiama & $\mathrm{F}$ & 62 & 122 & 104 & 24 & 17 & $x$ & $x$ \\
\hline $2017-386$ & PO775 & C. nimbasilvanus & sZiama & $\mathrm{M}$ & 72 & 129 & 116 & 27 & 16 & $x$ & $x$ \\
\hline $2017-388$ & PO792 & C. nimbasilvanus & sZiama & $\mathrm{F}$ & 39 & 122 & 112 & 23 & 15 & $x$ & $x$ \\
\hline- & DV0057 & C. eburnea & Ziama/Diecke & - & - & - & - & - & - & - & $x$ \\
\hline- & OP831 & C. obscurior & Ziama/Diecke & $\mathrm{F}$ & 3 & 51 & 33 & 11 & 7 & $x$ & $x$ \\
\hline- & P1138 & C. obscurior & Ziama/Diecke & $\mathrm{F}$ & 4 & 57 & 35 & 10 & 8 & $x$ & $x$ \\
\hline- & P1142 & C. obscurior & Ziama/Diecke & $\mathrm{M}$ & 4 & 55 & 36 & 10 & 7 & $x$ & $x$ \\
\hline- & OP859 & C. obscurior & Ziama/Diecke & M & 4 & 58 & 33 & 11 & 7 & $x$ & $x$ \\
\hline 2012-1530 & $\mathrm{Cl} 294$ & C. olivieri & Sanguiebo & $\mathrm{F}$ & 12 & 102 & 58 & 16 & 11 & $x$ & $x$ \\
\hline $2012-1511$ & $\mathrm{Cl} 479$ & C. olivieri & Bakro & $\mathrm{M}$ & 44 & 139 & 79 & 20 & 13 & $x$ & $x$ \\
\hline 2013-845 & BH56 & C. olivieri & Bhoita & $M$ & 38 & 132 & 80 & 19 & 13 & $x$ & $x$ \\
\hline $2013-846$ & $\mathrm{BH} 57$ & C. olivieri & Bhoita & M & 35 & 129 & 87 & 21 & 11 & $x$ & $x$ \\
\hline 2013-848 & GUI243 & C. olivieri & Gagal & $\mathrm{F}$ & 24 & 116 & 66 & 16 & 10 & $x$ & $x$ \\
\hline 2013-834 & GUI632 & C. olivieri & Khoneya & $M$ & 26 & 125 & 68 & 18 & 10 & $x$ & $x$ \\
\hline $2012-1494$ & $\mathrm{Cl} 424$ & C. theresae & Touzoukro & $\mathrm{F}$ & 18 & 111 & 67 & 17 & 11 & $x$ & $x$ \\
\hline 2013-909 & $\mathrm{BH} 45$ & C. theresae & Bhoita & $\mathrm{M}$ & 15 & 97 & 56 & 15 & 8 & $x$ & $x$ \\
\hline 2013-901 & FR15 & C. theresae & Franfina & $\mathrm{M}$ & 11 & 89 & 51 & 14 & 9 & $x$ & $x$ \\
\hline 2013-903 & FR57 & C. theresae & Franfina & $\mathrm{F}$ & 9 & 91 & 58 & 15 & 10 & $x$ & $x$ \\
\hline $2013-904$ & FR90 & C. theresae & Franfina & $\mathrm{F}$ & 9 & 91 & 53 & 14 & 10 & $x$ & $x$ \\
\hline $2013-884$ & GUI782 & C. theresae & Tanganya & $\mathrm{F}$ & 11 & 91 & 53 & 9 & 8 & $x$ & $x$ \\
\hline 2013-885 & GUI792 & C. theresae & Tanganya & $\mathrm{M}$ & 10 & 93 & 55 & 14 & 10 & $x$ & $x$ \\
\hline 2013-887 & GUI826 & C. theresae & Tanganya & $\mathrm{M}$ & 9 & 90 & 56 & 15 & 10 & $x$ & $x$ \\
\hline 2013-894 & KD25 & C. theresae & Kodoko & $\mathrm{M}$ & 14 & 97 & 55 & 15 & 10 & $x$ & $x$ \\
\hline 2013-895 & KD27 & C. theresae & Kodoko & $M$ & 14 & 100 & 65 & 15 & 10 & $x$ & $x$ \\
\hline $2013-896$ & KD28 & C. theresae & Kodoko & $\mathrm{F}$ & 9 & 92 & 51 & 15 & 10 & $x$ & $x$ \\
\hline 2013-897 & KD31 & C. theresae & Kodoko & $M$ & 12 & 92 & 55 & 14 & 10 & $x$ & $x$ \\
\hline 2013-898 & KD32 & C. theresae & Kodoko & $\mathrm{M}$ & 12 & 95 & 52 & 16 & 11 & $x$ & $x$ \\
\hline 2013-899 & KD33 & C. theresae & Kodoko & $\mathrm{M}$ & 11 & 92 & 53 & 16 & 10 & $x$ & $x$ \\
\hline $2013-900$ & KD7 & C. theresae & Kodoko & $\mathrm{F}$ & 10 & 84 & 50 & 14 & 10 & $x$ & $x$ \\
\hline 2013-906 & MAC17 & C. theresae & Macenta & $\mathrm{F}$ & 9 & 86 & 60 & 15 & 9 & $x$ & $x$ \\
\hline
\end{tabular}

APPENDIX 4. - Correlations between Variables and Factors of the CVA on external measurements. Abbreviations: see Material and methods.

\begin{tabular}{lrrrc}
\hline & F1 & F2 & F3 & F4 \\
\hline HB & 0.950 & 0.199 & -0.003 & -0.240 \\
TL & 0.805 & -0.564 & -0.058 & -0.177 \\
HF & 0.566 & 0.026 & 0.094 & -0.819 \\
E & 0.748 & -0.093 & 0.595 & -0.278 \\
\hline
\end{tabular}


APPENDIX 5. - Confusion matrix for classification predictions of the sample for the CVA on external measurements. Abbreviations: $\mathbf{b}$, Crocidura buettikoferi Jentink, 1888; d, C. douceti Heim de Balsac, 1958; e, C. eburnea Heim de Balsac, 1958; g, C. grandiceps Hutterer, 1983; j, C. jouvenetae Heim de Balsac, 1958, C. muricauda (Miller, 1900); mu, S. megalura (Jentink, 1888); n, C. nimbae Heim de Balsac, 1956, o, C. obscurior Heim de Balsac, 1958; ol, C. olivieri (Lesson, 1827); sy, C. nimbasilvanus Hutterer, 2003; t, C. theresae Heim de Balsac, 1968.

\begin{tabular}{|c|c|c|c|c|c|c|c|c|c|c|c|c|c|c|}
\hline From/to & b & d & e & g & j & m & mu & $\mathbf{n}$ & 0 & ol & sy & th & Total & $\%$ correct \\
\hline $\mathrm{b}$ & 27 & 0 & 0 & 1 & 3 & 0 & 0 & 0 & 0 & 1 & 0 & 9 & 41 & $65.85 \%$ \\
\hline d & 1 & 8 & 0 & 0 & 1 & 0 & 0 & 0 & 0 & 0 & 0 & 1 & 11 & $72.73 \%$ \\
\hline e & 0 & 0 & 0 & 0 & 1 & 0 & 0 & 0 & 7 & 0 & 0 & 0 & 8 & $0.00 \%$ \\
\hline g & 7 & 0 & 0 & 6 & 0 & 0 & 0 & 1 & 0 & 2 & 1 & 2 & 19 & $31.58 \%$ \\
\hline j & 0 & 0 & 0 & 0 & 17 & 0 & 0 & 0 & 6 & 0 & 1 & 5 & 29 & $58.62 \%$ \\
\hline $\mathrm{m}$ & 0 & 0 & 0 & 0 & 0 & 2 & 6 & 0 & 0 & 0 & 0 & 0 & 8 & $25.00 \%$ \\
\hline $\mathrm{mu}$ & 0 & 1 & 0 & 0 & 1 & 2 & 10 & 0 & 1 & 0 & 0 & 0 & 15 & $66.67 \%$ \\
\hline $\mathrm{n}$ & 2 & 0 & 0 & 0 & 0 & 0 & 0 & 0 & 0 & 0 & 0 & 5 & 7 & $0.00 \%$ \\
\hline 0 & 0 & 0 & 0 & 0 & 0 & 0 & 0 & 0 & 45 & 0 & 0 & 0 & 45 & $100.00 \%$ \\
\hline ol & 0 & 0 & 0 & 1 & 0 & 0 & 0 & 1 & 0 & 15 & 1 & 1 & 19 & $78.95 \%$ \\
\hline sy & 0 & 0 & 0 & 0 & 0 & 0 & 0 & 0 & 0 & 0 & 11 & 0 & 11 & $100.00 \%$ \\
\hline th & 8 & 0 & 0 & 1 & 2 & 0 & 0 & 0 & 0 & 1 & 0 & 27 & 39 & $69.23 \%$ \\
\hline Total & 45 & 9 & 0 & 9 & 25 & 4 & 16 & 2 & 59 & 19 & 14 & 50 & 252 & $66.67 \%$ \\
\hline
\end{tabular}

APPENDIX 6. - Correlations between the variables and the axes, CVA on skull measurements. Abbreviations: a, condyle-incisive length; b, nasal width; c, interorbital width; d, occipital greatest width; e, greatest maxillary width; $\mathbf{f}$, upper tooth row length; $\mathbf{g}$, height of the skull at M2 level; $\mathbf{h}$, greatest braincase height; $\mathbf{i}$, mandibular length; $\mathbf{j}$, lower tooth row length; $\mathbf{k}$, greatest length between extremities of the coronoid and angular processes.

\begin{tabular}{|c|c|c|c|c|c|c|c|c|c|c|c|}
\hline & F1 & F2 & F3 & F4 & F5 & F6 & F7 & F8 & F9 & F10 & F11 \\
\hline a & 0.995 & 0.045 & -0.034 & 0.066 & 0.007 & 0.011 & 0.019 & 0.022 & -0.029 & 0.021 & 0.016 \\
\hline b & 0.941 & -0.166 & -0.037 & -0.050 & -0.114 & 0.006 & 0.139 & 0.117 & -0.050 & 0.185 & 0.006 \\
\hline c & 0.947 & -0.041 & 0.253 & -0.024 & 0.065 & -0.134 & 0.035 & 0.051 & 0.057 & 0.042 & 0.071 \\
\hline d & 0.964 & 0.067 & 0.122 & 0.041 & 0.059 & 0.146 & 0.096 & 0.067 & -0.025 & 0.070 & 0.078 \\
\hline e & 0.984 & 0.060 & -0.008 & 0.052 & -0.043 & -0.020 & 0.114 & -0.080 & -0.056 & -0.015 & -0.021 \\
\hline$f$ & 0.986 & -0.086 & 0.029 & -0.026 & -0.057 & 0.047 & 0.062 & -0.061 & -0.045 & -0.041 & 0.051 \\
\hline $\mathrm{h}$ & 0.922 & 0.048 & 0.212 & 0.174 & -0.120 & 0.059 & -0.047 & 0.191 & -0.100 & -0.032 & -0.063 \\
\hline g & 0.940 & -0.170 & 0.093 & 0.167 & 0.042 & 0.055 & -0.048 & -0.085 & -0.051 & 0.185 & -0.012 \\
\hline i & 0.992 & 0.089 & -0.025 & -0.018 & 0.027 & 0.003 & -0.004 & 0.000 & -0.071 & 0.029 & -0.020 \\
\hline $\mathrm{k}$ & 0.944 & -0.106 & -0.041 & 0.024 & 0.167 & 0.011 & 0.091 & 0.067 & -0.219 & -0.086 & 0.002 \\
\hline j & 0.986 & 0.063 & -0.036 & -0.038 & 0.000 & 0.009 & 0.038 & -0.006 & 0.064 & -0.019 & -0.120 \\
\hline
\end{tabular}

APPENDIX 7.- Confusion matrix AFD skull measurements. Abbreviations: b, Crocidura buettikoferi Jentink, 1888; d, C. douceti Heim de Balsac, 1958; e, C. eburnea Heim de Balsac, 1958; g, C. grandiceps Hutterer, 1983; j, C. jouvenetae Heim de Balsac, 1958, C. muricauda (Miller, 1900); mu, S. megalura (Jentink, 1888); n, C. nimbae Heim de Balsac, 1956, o, C. obscurior Heim de Balsac, 1958; ol, C. olivieri (Lesson, 1827); sy, C. nimbasilvanus Hutterer, 2003; t, C. theresae Heim de Balsac, 1968.

\begin{tabular}{|c|c|c|c|c|c|c|c|c|c|c|c|c|c|c|}
\hline From/to & b & d & e & g & $\mathbf{j}$ & m & $\mathrm{mu}$ & $\mathbf{n}$ & o & ol & sy & th & Total & $\%$ correct \\
\hline $\mathrm{b}$ & 33 & 0 & 0 & 0 & 0 & 0 & 0 & 0 & 0 & 0 & 0 & 8 & 41 & $80.49 \%$ \\
\hline d & 0 & 11 & 0 & 0 & 0 & 0 & 0 & 0 & 1 & 0 & 0 & 0 & 12 & $91.67 \%$ \\
\hline e & 0 & 0 & 2 & 0 & 0 & 0 & 0 & 0 & 3 & 0 & 0 & 0 & 5 & $40.00 \%$ \\
\hline g & 2 & 0 & 0 & 10 & 0 & 0 & 0 & 0 & 0 & 2 & 0 & 5 & 19 & $52.63 \%$ \\
\hline j & 0 & 0 & 0 & 0 & 28 & 0 & 1 & 0 & 0 & 0 & 0 & 0 & 29 & $96.55 \%$ \\
\hline $\mathrm{m}$ & 0 & 0 & 0 & 0 & 0 & 7 & 1 & 0 & 0 & 0 & 0 & 0 & 8 & $87.50 \%$ \\
\hline $\mathrm{mu}$ & 0 & 0 & 0 & 0 & 1 & 0 & 12 & 0 & 2 & 0 & 0 & 0 & 15 & $80.00 \%$ \\
\hline $\mathrm{n}$ & 0 & 0 & 0 & 0 & 0 & 0 & 0 & 7 & 0 & 0 & 0 & 0 & 7 & $100.00 \%$ \\
\hline 0 & 0 & 1 & 1 & 0 & 0 & 0 & 2 & 0 & 35 & 0 & 0 & 0 & 39 & $89.74 \%$ \\
\hline ol & 0 & 0 & 0 & 0 & 0 & 0 & 0 & 0 & 0 & 19 & 0 & 0 & 19 & $100.00 \%$ \\
\hline sy & 0 & 0 & 0 & 0 & 0 & 0 & 0 & 0 & 0 & 0 & 11 & 0 & 11 & $100.00 \%$ \\
\hline th & 8 & 0 & 0 & 0 & 1 & 0 & 0 & 0 & 0 & 1 & 0 & 29 & 39 & $74.36 \%$ \\
\hline Total & 43 & 12 & 3 & 10 & 30 & 7 & 16 & 7 & 41 & 22 & 11 & 42 & 244 & $83.61 \%$ \\
\hline
\end{tabular}


ApPENDIX 8. - Nimba shrews skins with field numbers: A, MNHN-ZM-2014-900 (LB07) C. buettikoferi Jentink, 1888 Camp 4; B, MNHN-ZM-2012-1079 (NIM217) C. grandiceps Hutterer, 1983 Gouan; C, MNHN-ZM-2012-1158 (NIM201) C. olivieri (Lesson, 1827) Gbié; D, MNHN-ZM-2012-1111 (NIM232) C. muricauda (Miller, 1900) Gouan; E, MNHN-ZM-2012-1180 (NIM 301) C. theresae Heim de Balsac, 1968 Gouan; F, MNHN-ZM-MO-1981-492 C. nimbae Heim de Balsac, 1956 Holotype Zouguepo; G, MNHN-ZM-MO-1981-483 C. eburnea Heim de Balsac, 1958 Mt Tonkui; H, MNHN-ZM-2012-1123 (NIM 219$)$ C. obscurior Heim de Balsac, 1958 Gouan.
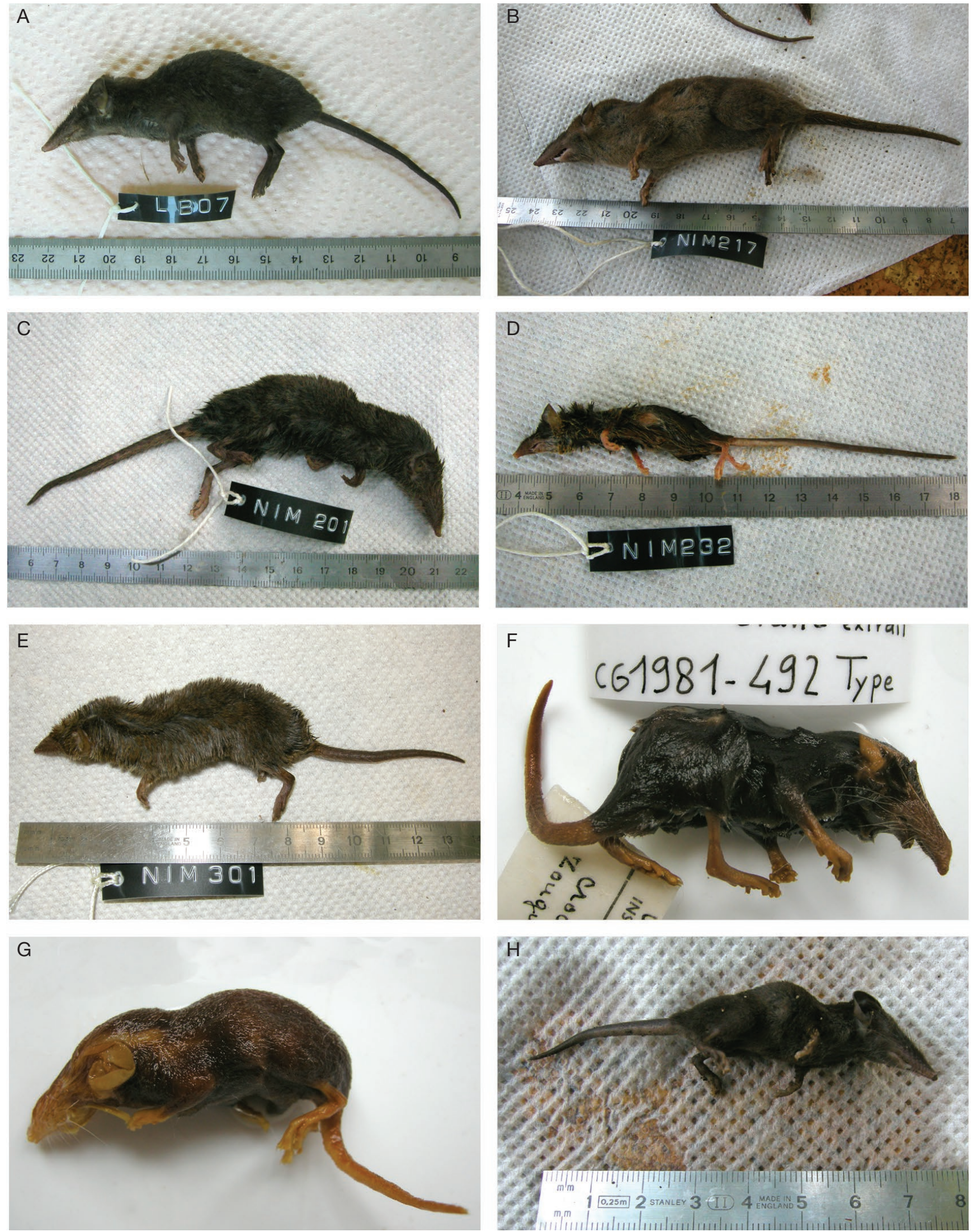